Notre Dame Law School

NDLScholarship

Journal Articles

Publications

$1-1984$

\title{
Federal Power over Indians: Its Sources, Scope, and Limitations
}

Nell Jessup Newton

Notre Dame Law School, nell.newton@nd.edu

Follow this and additional works at: https://scholarship.law.nd.edu/law_faculty_scholarship

Part of the Indian and Aboriginal Law Commons

\section{Recommended Citation}

Nell J. Newton, Federal Power over Indians: Its Sources, Scope, and Limitations, 132 U. Pa. L. Rev. 195 (1984).

Available at: https://scholarship.law.nd.edu/law_faculty_scholarship/1202

This Article is brought to you for free and open access by the Publications at NDLScholarship. It has been accepted for inclusion in Journal Articles by an authorized administrator of NDLScholarship. For more information, please contact lawdr@nd.edu. 


\section{University of Pennsylvania Law Review}

FOUNDED 1852

Formerly

American Law Register

\section{FEDERAL POWER OVER INDIANS: ITS SOURCES, SCOPE, AND LIMITATIONS}

\section{NeLl Jessup Newton $\dagger$}

\section{INTRODUCTION}

Judicial deference to federal legislation affecting Indians is a theme that has persisted throughout the two-hundred-year history of American Indian law. The Supreme Court has sustained nearly every piece of federal legislation it has considered directly regulating Indian tribes, whether challenged as being beyond federal power or within that power but violating individual rights. ${ }^{1}$ This judicial deference often has been justified by invoking federal plenary power to regulate Indian affairs and the political question doctrine's requirement of deference to the political branches. Indeed, not until 1977 did the Court explicitly repudiate use of the political question doctrine to bar equal protection

† Associate Professor of Law, Catholic University of America. B.A. 1973, University of California, Berkeley; J.D. 1976, University of California, Hastings College of the Law. I wish to thank Robert Clinton of the University of Iowa College of Law and Roger Hartley of the Catholic University Law School for their many helpful comments and criticisms of earlier drafts of this article. I would also like to acknowledge the fine research assistance of Nancy Dunn and Aline Henderson, both of the Catholic University Law School.

1 In only one case did the Court invalidate a congressional law as violating Indian property rights, but it was careful to distinguish earlier cases by stressing that the rights at issue were individual and not tribal property rights. Choate v. Trapp, 224 U.S. $665,671,678$ (1912); see infra notes $347-50$ and accompanying text. 


\section{challenges to federal legislation regulating Indian affairs. ${ }^{2}$}

The judiciary's frequent invocation of federal plenary power over Indian affairs is curious since the Constitution does not explicitly grant the federal government a general power to regulate Indian affairs. One suspects, therefore, that, as in other areas of constitutional law, the terms "plenary power"s and "political question"4 are not so much justifications for decisional outcomes as they are restatements of the Court's intent to defer to the other branches of government and, concomitantly, to abdicate any role in defining the unique status of Indian tribes in our constitutional system or accommodating their legitimate claims of tribal sovereignty and preservation of property.

The unique nature of Indian tribes in our federal system helps to explain this deference. Through almost two hundred years of constitutional adjudication, the courts have labored to decipher the Constitution's exquisite tensions allocating power between the federal and state governments and between governmental power and individual rights. Yet, when the issue of Indian tribal sovereignty is placed within this matrix, none of the Constitution's familiar power allocation rules seem to fit. First of all, Indian tribes are not merely private associations. ${ }^{b}$

${ }^{2}$ Delaware Tribal Business Comm. v. Weeks, 430 U.S. 73, 84 (1977) (citing Morton v. Mancari, 417 U.S. 535, 555 (1974)).

3 The term "plenary power" has been used to describe several distinct concepts. Engdahl has synthesized three, Engdahl, State and Federal Power over Federal Property, 18 ARIz. L. REv. 283, 363-66 (1976): first, plenary meaning exclusive power, as, for example, the exclusive power of Congress to spend federal money, U.S. ConST. art. I, $\S 8, \mathrm{cl}$. 1; second, plenary meaning an exercise of power capable of preempting state law, as, for example, Congress's commerce power, U.S. ConST. art. I, § 8, cl. 3; third, plenary meaning unlimited power. This final category includes two subgroups: (a) power unlimited by other textual provisions of the Constitution; and (b) power unlimited as to the objectives Congress might pursue. An example of the latter is the use of the taxing power to deter conduct Congress deems inimical to the public welfare, but which it cannot prohibit directly. See, e.g., United States v. Kahriger, 345 U.S. 22 (1953) (federal tax on bookmakers upheld).

In Indian law, the term plenary power has been used with each of these connotations. See, e.g., Worcester v. Georgia, 31 U.S. (6 Pet.) 515, 561 (1832) (Marshall, C.J.) (federal law is exclusive and preemptive of state law); see also Lone Wolf v. Hitchcock, 187 U.S. 553, 564-65 (1903) (congressional plenary authority over Indians is political and not subject to judicial control). Contra, Delaware Tribal Business Comm. v. Weeks, 430 U.S. 73 (1977) (congressional plenary power over Indian affairs does not mean that due process challenge is not justiciable). As to the category of unlimited power, if a general power over Indian affairs exists, any legislation relating to Indians would be permissible. See, e.g., United States v. Rogers, 45 U.S. (4 How.) 567, 572 (1840) (congressional policy decisions dealing with Indians are not open to question by the judiciary); see also Felix S. Cohen's HandBoor of FEDERAL Indian LAW 211 (R. Strickland \& C. Wilkinson eds. 1982) [hereinafter cited as 1982 HANDBOOK].

4 See Baker v. Garr, 369 U.S. 186, 217 (1962); see also Henkin, Is There a "Political Question" Doctrine?, 85 Yale L.J. 597, 606, 622 (1976).

8 'Indian tribes within 'Indian country' are a good deal more than 'private, volun- 
They elect political officers who enact civil and criminal laws administered by tribal courts, and they hold title to tribal land. In short, they assert a measure of political sovereignty over the persons and property within the boundaries of their reservations. ${ }^{6}$

In a constitutional sense, however, Indian tribes are strange sovereigns. Unlike foreign countries, dealt with at arms length by the federal government, Indian tribes are subject to the ultimate sovereignty of the federal government: they govern within the territorial borders of the United States, and their members are United States citizens. Yet, Indian tribes are "domestic dependent nations," and not states of the Union able to claim rights against the central government through the traditions and constitutional structures supporting federalism. ${ }^{\mathbf{8}}$

At the same time Indian tribes do not have a full property interest in their lands; federal power to govern tribes has been translated into federal ownership of an interest in tribal lands, with a concomitant increase in federal power to confiscate that land. ${ }^{9}$

How then, do Indian tribes and tribal claims fit within our constitutional framework? In particular, what constitutional arguments are available to an Indian tribe seeking to limit the exercise of federal power encroaching on the tribe's political sovereignty or its property interests? How has judicial deference to Congress impeded the development of constitutional protection of tribal rights? These questions are the subjects of the present Article.

Because extraordinary deference to congressional power over Indians is closely related to the courts' failure to protect Indian tribal rights, this Article begins by tracing the history of federal power over Indians, with special focus on the development of the Plenary Power Doctrine. History reveals that the original reasons for the doctrine are no longer applicable. While the doctrine has been narrowed in recent cases, the courts continue their truncated role, invoking plenary power, or its equivalent, and deferring to Congress to accommodate the competing interests affected by legislation. The music has stopped, but the melody lingers on.

tary organizations' . . . ." United States v. Mazurie, 419 U.S. 544, 557 (1975).

B See, e.g., Merrion v. Jicarilla Apache Tribe, 455 U.S. 130 (1982) (tribe's inherent sovereignty upheld exercise of tribal power to impose oil and gas severance tax on non-Indian lessees). For a recent review of the sources of and limitations upon tribal sovereignty, see 1982 HANDBOoK, supra note 3, at 229-57.

7 Cherokee Nation v. Georgia, 30 U.S. (5 Pet.) 1, 15-18 (1831).

${ }^{8}$ See, e.g., National League of Cities v. Usery, 426 U.S. 833 (1976) (state sovereignty can operate as a limitation on federal commerce power); $c f$. Hodel v. Virginia Surface Mining \& Reclamation Ass'n, 452 U.S. 264 (1981) (federal mining act did not interfere with states' traditional governmental function).

- See infra text accompanying notes 58-80 \& 122-28. 
Undue deference to congressional power over Indians only partially explains the consistent failure of tribal claims against the government. A second cause is the unusual nature of those claims-especially claims to preserve tribal sovereignty and property. Again, primarily because of the unique nature of Indian tribes, these claims do not fit neatly into the Constitution's guarantee of due process of law, and its equal protection component.

Upon closer examination, however, the unique features of Indian tribes suggest constitutional limits on government actions affecting tribal rights. First, some have argued that when confronted with the question of dealing with Indians the framers opted to respect tribal sovereignty by vesting power to deal with Indian tribes in the federal government alone, and limiting that power to legislation dealing with commerce with Indian tribes. ${ }^{10}$ Beyond that historical and textual argument, the same constitutional traditions and doctrines that accord strict judicial scrutiny to legislative actions interfering substantially with fundamental rights may apply to laws affecting tribal property and sovereignty rights. While such tribal rights at first seem outside the mainstream values shared by Americans, respect for tribal rights simply involves acceptance both of cultural diversity and the morality of promise keeping-values deeply rooted in this society. Similarly, the protection afforded certain classes, such as racial and ethnic minorities discriminated against in the political process, should extend to the appropriate entity for evaluating Indian political power, the individual tribe. The second portion of this Article will, thus, focus on fifth amendment limitations on federal power to regulate tribal sovereignty and property rights.

In addition to these broad doctrinal arguments this analysis also turns to a detailed examination of relatively recent cases suggesting an alternative basis for heightened judicial scrutiny of legislation affecting Indians. ${ }^{11}$ Several issues will be addressed: first, whether the Court in recent cases has formulated a "substantive limitation" on congressional power over Indian affairs; second, if such a limitation exists, its nature and scope; and third, the variables conditioning the application of this limitation, especially regarding tribal political sovereignty and property interests. The Article concludes that the courts can and should apply an intermediate standard of scrutiny in reviewing the exercise of federal power encroaching on these interests.

11 See infra notes 249-92 and accompanying text. 


\section{Overview of Congressional Power to REgULATE INDIAN AFFAIRS}

The mystique of plenary power has pervaded federal regulation of Indian affairs from the beginning. ${ }^{12}$ While the Articles of Confederation contained a general power over Indian affairs, ${ }^{13}$ the Constitution enumerates only one power specific to these affairs, the power " $[t]$ o regulate Commerce . . . with the Indian tribes."14 The Plenary Power Doctrine, a fixture of American Indian law since John Marshall provided its first justification in $1832,{ }^{15}$ can be traced not only to this commerce power but also to the treaty, war, and other foreign affairs powers, ${ }^{16}$ as well as the property power. ${ }^{17}$ Each has been characterized, historically, as vesting Congress (or the President) with almost unlimited power in contexts not involving Indians. ${ }^{18}$

12 Federal plenary power over Indians is regarded as a major doctrine in Indian law today. See, e.g., 1 American Indian Policy Review Comm'n, Final Report 106-07 (1977) [hereinafter cited as Policy Review Commission Final RePORT]; R. Barsh \& J. Henderson, The Road: Indian Tribes and Political Liberty 11234 (1980); 1982 HANDBOOK, supra note 3, at 207-12.

1s "The United States . . . shall also have the sole and exclusive right and power of .. . regulating the trade and managing all affairs with the Indians, not members of any of the States provided that the legislative right of any State within its own limits be not infringed or violated." U.S. ARTICLES of CoNfEDERATION art. IX (1777). This language, designed to strike a compromise between state and federal interests by granting states control over assimilated Indians within their borders while giving the new government supremacy in dealing with Indian tribes, produced constant federal-state friction during the period of government under the Articles. See Clinton \& Hotopp, Judicial Enforcement of the Federal Restraints on Alienation of Indian Land: The Origins of the Eastern Land Claims, $31 \mathrm{ME}$. L. Rev. 17, 23-28 (1980). See generally F. Prucha, American Indian Policy in the Formative Years 28-31 (1962) (background on article IX of the Articles of Confederation).

14 U.S. ConST. art. I, $\S 8$, cl. 3.

16 Worcester v. Georgia, 31 U.S. (6 Pet.) 515, 557-62 (1832).

16 U.S. ConST. art. II, \& 2 (treaty); id. art. I, \& 8, cls. 11-16 (congressional war powers); id. art. II, $\S 2$ (presidential war powers). The Court has stated that foreign affairs powers are inherent in national sovereignty, and not granted by the Constitution. United States v. Curtiss-Wright Export Corp., 299 U.S. 304, 318 (1936). See generally Henkin, The Treaty Makers and the Law Makers: The Law of the Land and Foreign Relations, 107 U. PA. L. REv. 903, 918-22 (1959) (development of foreign affairs power).

17 U.S. Const. art. IV, § 3 (property clause).

${ }^{18}$ See, e.g., Mathews v. Diaz, 426 U.S. 67, 81-82 (1976) ("The reasons that preclude judicial review of political questions also dictate a narrow standard of review of decisions made by the Congress or the President in the area of immigration and naturalization.") (citing Baker v. Carr, 369 U.S. 186, 217 (1962)); Kleindienst v. Mandel, 408 U.S. 753 (1972) (congressional "plenary authority" over aliens); Korematsu v. United States, 323 U.S. 214 (1944) (war powers justified interning Japanese during World War II); United States v. Curtiss-Wright Export Corp., 299 U.S. 304 (1936) (broad foreign affairs powers of President and Congress); United States v. Gratiot, 39 U.S. (14 Pet.) 526, 537 (1840) (article IV property power "without limitation"); see also Geofroy v. Riggs, 133 U.S. 258, 266-67 (1890) (treaty power is unlimited with 


\section{A. The Treaty Era: Foreign Affairs and Indian Commerce (1776-1871)}

The absence of a general power over Indian affairs in the Constitution is not surprising to students of history, for at the time the Constitution was drafted, the framers regarded Indian tribes as sovereign nations, albeit nations that would soon either move West, assimilate, or become extinct. ${ }^{18}$ Thus, the same powers that sufficed to give the federal government a free rein in the international arena were viewed as sufficient to enable the new government to deal adequately with the Indian tribes.

In formulating federal policy toward Indian tribes in the early years of the Constitution, President Washington and Secretary of War Knox followed the policy promulgated by the British Crown-though not always followed by individual colonies ${ }^{20}$ - of dealing with Indian tribes as sovereign nations. Their principal reason was practical: earlier attempts by individual colonies and some states under the Articles of Confederation to assert power over Indian tribes, especially power to seize tribal lands, had caused conflicts. According to one historian, " $[t]$ he country, precariously perched among the sovereign nations of the world, could not stand the expense and strain of a long drawn-out Indian war."21

Washington and Knox advocated a policy of respect for existing treaty promises. In addition they recommended that a series of new treaties be negotiated for the purpose of acquiring Indian land by consent in an orderly fashion; the treaties would contain promises to protect Indian tribes and tribal land from white incursions in exchange for the land cessions. ${ }^{22}$ This policy of dealing with Indian tribes as nations capable of executing treaties continued until $1871 .^{28}$

respect to the objectives Congress might pursue: "[I]t is not perceived that there is any limit to the questions which can be adjusted [by treaty] touching any matter which is properly the subject of negotiation with a foreign country"); Henkin, supra note 16, at 919-30 (congressional foreign affairs power); $c f$. L. TRIBE, AMERICan ConstituTIONAL LAW $\$ 5-16$ (1978) (Court defers unduly in individual rights cases to congressional power in the area of foreign affairs).

18 See, e.g., R. Berkhofer, JR., The WhIte Man's Indian 134-45 (1978); F. Prucha, supra note 13, at 213-27; S. TyleR, A History of INDIAN Policy 32-43 (1973).

${ }^{20}$ For a history of the contradictions in Indian policy during the colonial period, see Clinton \& Hotopp, supra note 13, at 19-29; Clinton, Book Review, 47 U. CHI. L. REv. 846, 850-57 (1980).

${ }^{21}$ F. Prucha, supra note 13, at 44; see also A. Wallace, The DeATh AND REBIRTH OF THE SENECA 159-62 (1969) (Indian battles resulting in high United States casualties).

${ }^{22}$ F. PRUCHA, supra note 13 , at 44-49.

${ }^{23}$ In that year, the House of Representatives attached a rider to the Indian appro- 
The treaty powers of Congress and the executive were sufficient to carry out this early policy. In addition to ratifying treaties, Congress also affected Indian affairs by means of the Trade and Intercourse Acts, first enacted in $1790 .{ }^{24}$ These laws originally were designed to effectuate treaty promises of protection by imposing sanctions on individuals and states who had infringed on Indian land or dealt with Indians in violation of treaties. ${ }^{25}$

The judiciary further solidified the analogy of Indian affairs to foreign affairs. In Worcester $v$. Georgia ${ }^{28}$ Chief Justice John Marshall upheld the supremacy of federal over state power regarding Indian tribes, an issue that threatened to split the nation apart at that time, but which has never seriously been open to question since then. ${ }^{27}$

priations act stating that no more treaties were to be made with Indians. Act of Mar. 3, 1871 , ch. 120, $\S 1,16$ Stat. 544, 566 (codified at 25 U.S.C. $\S 71$ (1976)). The effect of this rider was to serve notice on the Senate and the President that the House would enforce its desire for more participation in Indian affairs by refusing to appropriate any money to finance treaty promises. Although Congress began governing Indians by legislation, it is important to note that the end of the treaty era did not end all consensual relations between the government and Indian tribes, especially with regard to land cessions. The executive negotiated agreements regarding land cessions, which were then sent to both houses of Congress for ratification. See 1982 HandBook, supra note 3, at 127-28.

24 Trade and Intercourse Act of July 22, 1790, ch. 33, 1 Stat. 137 (codified as amended at 25 U.S.C. $\S 177$ (1976)). Particularly important was a provision, still in force today, voiding any sales of land by "any Indians, or any nation or tribe of Indians" without the consent of the United States. Id. See 1982 HandBook, supra note 3, at 109-11 \& $\mathrm{nn}$. 387-96. This law provides the basis for the recent claims by Indian tribes living in the original 13 states that sales of their land to the states without federal consent are void. See, e.g., Oneida Indian Nation v. County of Oneida, 719 F.2d 525 (2d Cir. 1983); Oneida Indian Nation v. County of Oneida, 414 U.S. 661 (1974). See generally Clinton \& Hotopp, supra note 13; O'Toole \& Tureen, State Power and the Passamaquoddy Tribe: "A Gross National Hypocrisy?," 23 ME. L. REv. 1 (1971). For a comprehensive history of the Trade and Intercourse Acts, see F. PRUCHA, supra note 13.

${ }^{25}$ See F. Prucha, supra note 13, at 44-49. These laws were not controversial exercises of congressional power. Any doubt regarding congressional ability to rely on the necessary and proper clause, U.S. ConsT. art I, $\S 8, \mathrm{cl}$. 18 , to execute treaties would have been quieted by the commerce clause's commitment of commerce with the Indian tribes to Congress.

28 31 U.S. (6 Pet.) 515 (1832). Georgia had attempted to assert jurisdiction and ownership rights over the gold-rich lands of the Cherokee Nation. Invalidating the Georgia law, the Court held that the Constitution assigned to the federal government exclusive power to deal with Indians. Consequently the Court concluded that the exclusivity of federal power alone would bar any state law, and that federal laws as well as treaties preempted state laws. Id. at 561-62.

${ }^{27}$ See Burke, The Cherokee Cases: A Study in Law, Politics, and Morality, 21 Stan. L. REv. 500 (1969). The major exception is the issue of off-reservation fishing rights in Washington state, called "[o]ne of the most significant state-federal conflicts since the Civil War." D. Getches, D. Rosenfelt \& C. Wilkinson, Cases and Materials on FEDERal Indian Law 618 (1979). For a succinct history of this dispute, see Fishing in Western Washington-A Treaty Right, a Clash of Cultures, in U.S. Comm'n on Civil Rights, Indian Tribes: A ConTinuing QUEST FOR SuR- 
Chief Justice Marshall premised much of his eloquent defense of federal power on his view of the Indian tribes as sovereign nations whose rights of self-government predated the Constitution and whose dealings with the United States were governed by principles of international as well as constitutional law. ${ }^{28}$ Consequently, he found ample authority in the Constitution for federal power: "[The Constitution] confers on congress the powers of war and peace; of making treaties, and of regulating commerce with foreign nations, and among the several states, and with the Indian tribes. These powers comprehend all that is required for the regulation of our intercourse with Indians."20

Although the Court.in Worcester recognized that Indian tribes possess inherent sovereignty rights, the decision was really a defense of federal over state power, not a defense of Indian tribal sovereignty-the tribe was not even a party to the suit. Indeed, by relying on federal foreign relations power to free tribal sovereignty from state control, Worcester subjugated that sovereignty to the will of Congress and set the stage for a tradition of deference to Congress in Indian affairs analogous to that deference accorded Congress (or the President) in foreign affairs. $^{30}$

One legacy of Worcester, then, is that courts applied to Indian affairs doctrines peculiar to the federal foreign affairs power without necessarily distinguishing the special status of Indian tribes as domestic rather than foreign nations. For instance, under the last-in-time rule, Congress can abrogate a treaty with a foreign country, merely by passing a later statute conflicting with it. ${ }^{31}$ Early on, this doctrine was applied to treaties with Indians; ${ }^{32}$ moreover, courts continue to apply the doctrine today when Indian tribes are no longer regarded as foreign nations. ${ }^{33}$

vival 61-100 (1981) [hereinafter cited as Givil Rights Commission REPORT].

${ }^{28}$ The Indian nations had always been considered as distinct, independent political communities, retaining their original natural rights .... The constitution, by declaring treaties already made, as well as those to be made, to be the supreme law of the land, has adopted and sanctioned the previous treaties with the Indian nations, and consequently admits their rank among those powers who are capable of making treaties.

31 U.S. (6 Pet.) at 559.

${ }^{28}$ Id. (emphasis added).

so See supra note 18.

31 E.g., Chinese Exclusion Case, 130 U.S. 581 (1889).

s2 The Cherokee Tobacco, 78 U.S. (11 Wall.) 616, 621 (1870) (treaties with Indian tribes have "no higher sanctity" than treaties with foreign nations).

ss See, e.g., Yankton Sioux Tribe v. United States, 623 F.2d 159, 181 (Ct. Cl. 1980) (statute permitting Secretary of Interior to pay out shares of tribal funds to individuals abrogated treaty promise that payment for land sale be held in tribal trust fund); see also Rosebud Sioux Tribe v. Kneip, 430 U.S. 584 (1977) (statutes opening 
Another example of the uncritical borrowing of foreign affairs doctrines was the frequent invocation of the political question doctrine, ${ }^{34}$ relatively common in foreign affairs, ${ }^{\mathbf{3 6}}$ as a justification for failing to question congressional power in Indian cases, ${ }^{\mathbf{3}}$ even those raising individual rights concerns. ${ }^{37}$ For instance, although the integrity of tribal sovereignty was protected from state incursions in Worcester, the federal government later forced the Cherokee Nation to march to Indian territory by negotiating a treaty with a minority faction of the tribe. ${ }^{38}$

parts of treaty reservation to settlers disestablished reservation); $c f$. Confederated Salish \& Kootenai Tribes v. Namen, 665 F.2d 951 (9th Cir. 1982) (distinguishing Rosebud Sioux in holding statute opening up treaty reservation did not disestablish reservation). In Rosebud Sioux the Court held that the decisive factor in determining abrogation of a treaty was a clearly expressed congressional intent. 430 U.S. at 586; see also Confederated Salish, 665 F.2d at 954-60. The courts are divided as to whether this intent must be explicitly expressed on the face of the later statute or whether it may be discovered from the surrounding circumstances. Compare United States v. White, 508 F.2d 453 (8th Cir. 1974) (face of the act did not demonstrate intent to abrogate) with United States v. Fryberg, 622 F.2d 1010 (9th Cir.) (surrounding circumstances indicated congressional intent to abrogate), cert. denied, 449 U.S. 1004 (1980). For a thorough discussion of this controversy, see Comment, Statutory Construction-Wildlife Protection Versus Indian Treaty Hunting Rights, 57 WASH. L. REv. 225 (1981); see also Wilkinson \& Volkman, Judicial Review of Indian Treaty Abrogation: "As Long as Water Flows, or Grass Grows Upon the Earth"- - How Long a Time is That?, 63 CALIF. L. REV. 601 (1975).

s4 E.g., Baker v. Carr, 369 U.S. 186 (1962). Whether or not the political question doctrine actually exists is the subject of a great deal of controversy. See L. TRIBE, supra note 18, $\S 3-16$, at 71-79 (summarizing the doctrine and competing views). Nevertheless, its invocation by a court, even in a case in which the court actually reaches the merits, is an almost certain indication that the party challenging political power is going to lose the case.

ss See, e.g., Goldwater v. Carter, 444 U.S. 996, 1002 (1979) (Rehnquist, J., concurring) (political question doctrine barred review of presidential authority to abrogate Panama Canal Treaty); Chicago \& S. Air Lines v. Waterman S.S. Corp., 333 U.S. 103,111 (1948) (holding that presidential orders concerning international air routes are "political not judicial"); United States v. Curtiss-Wright Export Co., 299 U.S. 304 (1936) (upholding presidential authority to declare arms embargo punishable by criminal sanctions); Fong Yue Ting v. United States, 149 U.S. 698, 713 (1893) (power over foreign relations "vested in the political departments of the government"); see also Henkin, supra note 4 (despite language regarding political questions in foreign affairs cases discussed, the political question doctrine was not necessary to the decisions).

${ }_{36}$ See, e.g., United States ex rel. Hualpai Indians v. Santa Fe Pac. R.R., 314 U.S. 339,347 (1941) ("The manner, method and time of such extinguishment [of aboriginal Indian title] raise political, not justiciable, issues."); Beecher v. Wetherby, 95 U.S. 517, 525 (1877) (" $[\mathrm{A}] \mathrm{ction}$ towards Indians with respect to their lands is a question of governmental policy .....”).

${ }_{37}$ See, e.g., Tee-Hit-Ton Indians v. United States, 348 U.S. 272, 281 (1955) (Indians not entitled to compensation under fifth amendment for taking of timber by United States from aboriginal lands. The "power of Congress is supreme."); Lone Wolf v. Hitchcock, 187 U.S. 553, 565 (1903) (political question doctrine barred review of tribal due process claim).

${ }_{38}$ Treaty with the Cherokees at New Echota, Dec. 29, 1835, 7 Stat. 478. The pressures from state and public officials created two factions among the Cherokee Nation, the Treaty Party, comprising the elite mixed bloods, and the Ross faction, sup- 
Despite the immediate protest of nearly all of the Cherokee people to the President and to Congress, removal was ordered. ${ }^{38}$ Judicial recourse would have been unavailing: the political question doctrine would have barred the courts from questioning the procedures leading up to the treaty. ${ }^{40}$

Although courts analogized Indian nations to foreign nations in finding congressional power to deal with them, it is important to note that the Court did not view Indian tribes as possessing all the attributes of sovereignty of a foreign nation. In the first Cherokee Case, Cherokee Nation $v$. Georgia, ${ }^{43}$ the Court held that Indian nations were not foreign states for the purpose of invoking the Supreme Court's original jurisdiction. ${ }^{2}$ The Gourt reasoned that the Cherokee Nation was "a distinct political society, separated from others, capable of managing its own affairs, and governing itself . . ."43 Nevertheless, the nation was neither a state of the union nor a foreign state, but a "domestic dependent nation" incapable of conducting foreign relations with countries other than the United States. Instead "[t]heir relation to the United States resembles that of a ward to his guardian."44

In sum, from the beginning Indian tribes were in a truly anomalous position. Congress and the President viewed them as separate nations in some respects. Furthermore, individual Indians were regarded

porters of Chief John Ross. Ross, who had the support of most of the Cherokee people, was incarcerated while the Treaty Party representatives negotiated the treaty. The treaty, ratified at New Echota, the capital of the Cherokee Nation, by only 20 persons, ceded all the tribal land in Georgia in exchange for 7,000,000 acres of land in Indian Territory. French, The Death of a Nation, 4 AM. IND. J. 2, 3-4 (1978). For a description of the treaty, see 1982 HANDBOOK, supra note 3, at 84.

${ }^{39}$ A petition protesting the treaty signed by nearly 16,000 of the 17,000 members of the Cherokee people was presented to Congress. G. Foreman, Indian Removal 269 (new ed. 1953). Over 4,000 out of 16,000 Cherokees died in the camps where they awaited removal and along the Trail of Tears, as the route to Indian Territory came to be called. Id. at 294-312; see also G. Foreman, The Last Trek of The Indians (1946). For a political history of the removal legislation, see generally F. PRUCHA, supra note 13, at 238-49.

to Cf. Lone Wolf v. Hitchcock, 187 U.S. 553, $567-68$ (1903) (Court refused to address merits of claims of fraudulent misrepresentation and failure to secure consent of three-fourths of tribe as required by treaty).

4130 U.S. (5 Pet.) 1 (1831).

12 Id. at 16-17. The tribe argued that, as a foreign nation suing a state, it came within the article III grant of federal jurisdiction. U.S. CoNST. art. III, $\S 2$. Since the state was a defendant, the Supreme Court would have original jurisdiction. Id. § 3. For an analysis of the contemporary legal community's reaction to the Cherokee Nation's claim and the role of William Wirt, the tribe's attorney, see Burke, supra note 27. According to Burke, the tribe might have sought Supreme Court jurisdiction because Justice Johnson, who would have heard the case had they filed it in Circuit Court, was not favorable to their claim. Id. at 512 .

430 U.S. (5 Pet.) at 16.

14 Id. at 17. 
as domestic subjects, more akin to aliens than citizens, ${ }^{45}$ until Congress granted them universal citizenship in $1924 .^{46}$ The judicial deference traditionally accorded the political branches of the federal government in conducting foreign affairs and dealing with aliens attached to federal regulation of Indian affairs. As domestic dependent nations, Indian tribes possessed sovereignty, but could not invoke the jurisdiction of the federal courts. Indeed, the broad language in Cherokee Nation about the peculiar status of Indian tribes, created doubt that tribes had standing to sue in federal court, a matter that was subject to some question for many years. ${ }^{47}$ In short, the integrity of tribal sovereignty rested precariously on the whim of Congress owing, in the early years, to the Court's extraordinary deference to the political branches' exercise of the foreign affairs power in their dealings with the Indians.

\section{B. The End of the Treaty Era (1865-1871)}

In the years preceding the Givil War, especially during the 1830's to the 1850's, Congress had sought to remove the Eastern Indian tribes West of the Mississippi, ${ }^{18}$ but as settlers began opening up the West, continued removal began to be viewed as impossible. ${ }^{49}$ After the Givil War and the pacification of the last tribes of the plains, ${ }^{50}$ a movement began to assimilate Indians into American culture, by force if necessary. A policy of treating Indian tribes as separate nations with power over their own people on their own land was seen as antithetical to this new policy. ${ }^{\text {} 1}$

Divergent groups coalesced for very different reasons behind this

15 Sep Elk v. Wilkins, 112 U.S. 94, 99 (1884) (Indian born in United States and living apart from his tribe not a citizen under fourteenth amendment; Congress must by treaty or statute confer citizenship); see also Thayer, Report of the Law Committee, in AMERICANIZING THE AMERICAN INDIANS: WRITINGS BY THE "FRIENDS OF THE INDIAN" $1880-1900$, at 172-73 (F. Prucha ed. 1973) (1888 report by then Dean of Harvard Law School on the legal status of Indians); Pancoast, The Indian Before the Law, in id. 155, 158 (1884 study).

${ }^{16}$ Citizenship Act of 1924 , ch. 233,43 Stat. 253 (current version at 8 U.S.C. $\S$ 1401(b) (1982)).

17 See Clinton \& Hotopp, supra note 13, at 46 \& n.141; see also text accompanying notes $179-81$.

48 See generally 1982 HandBook, supra note 3, at 74-92 (removal treaties); G. Foreman, The Five Crvilized TRIBes (1934) (adjustment after removal until the Civil War); F. Prucha, supra note 13, at 213-49 (background of removal); id. at 25073 (formation of Indian country).

49 See, e.g., R. BERKhOFER, JR., supra note 19, at 165; S. TYLER, supra note 19, at $62-65,70-75$.

so By the 1880's many Indian tribes lived inside the boundaries of the states or territories that were on their way to statehood. See S. TYLER, supra note 19, at 70, 99, 104.

s1 See generally R. Berkhofer, JR., supra note 19, at 166-75. 
assimilationist policy. Some regarded Indians as barbarians who had to be civilized for their own security and the security of those living near them. It was believed that if Indians were citizens, individually owning small tracts of land, they would come under the civilizing effect of the life of a farmer or a rancher and abandon their nomadic and barbaric habits. Large portions of surplus reservation land could then be sold to settlers, who were clamoring for it. In addition, promises that reservation land would never be within the limits of a state would become meaningless with the end of the reservations; thus individual ownership would remove this barrier to statehood for the remaining territories. ${ }^{52}$ Other advocates of assimilation, members of the "Friends of the Indians" movement, were moved by more benign motives. ${ }^{53}$ They argued that only by becoming citizens, voters, and individual landowners would Indians be able to protect themselves and their land from the settlers and the federal government's dishonorable practice of "breaking ... several hundred treaties, concluded at different times during the last 100 years . . . ."

The House of Representatives ushered in the new "Era of Allotment and Assimilation," when it decreed in a rider to the Appropriations Act of 1871 that henceforth "[n]o Indian nation or tribe within the territory of the United States shall be acknowledged or recognized as an independent nation, tribe, or power with whom the United States may contract by treaty." that Indian affairs should no longer be a matter of foreign affairs now that the last remaining Indian tribes of a warlike nature had been subdued. ${ }^{\text {so }}$

Thus, the treatymaking era came to an end. Indian law became more a matter of domestic law, with Indians regarded as subjects to be governed, rather than foreign nationals. ${ }^{67}$

52 See Prucha, Introduction, in AMERICANIZING THE AMERICAN Indians, supra note 45, at 6-7; Washburn, The Historical Context of American Indian Legal Problems, 40 LAw \& Contemp. Probs. 12, 18 (1976).

s3 See generally Americanizing the AMERICAN Indians, supra note 45 (excerpts from the writings of the Friends of the Indians).

${ }^{64}$ H. Jackson, A Gentury of Dishonor 26 (1881 \& photo. reprint 1965). Ms. Jackson's indictment of federal policy sparked the reform movement.

65 Act of Mar. 3, 1871, ch. $120, \S 1,16$ Stat. 566 (codified at 25 U.S.C. $\S 71$ (1976)).

so The House had been excluded from policy making by the President and Senate, its role limited to appropriating money to satisfy treaties. The House had no power to take away the President and Senate's treaty powers, of course, but the rider gave notice that no further appropriations would be made to fulfill any new treaty obligations. See supra note 23; see also Antoine v. Washington, 420 U.S. 194, 201-03 (1975) (history of 1871 rider and its effect on later agreements with Indian tribes).

${ }^{67}$ As one indication of this change in attitude, in 1845 supervisory and appellate 


\section{The Plenary Power Era (1877-1930's) \\ 1. Bases for the Plenary Power Doctrine}

With the end of the treatymaking era came statutes designed to implement the new assimilationist policies. Many of these statutes could not be viewed as either effectuating treaty promises or regulating trade. Thus the Court was forced to develop new rationales to justify federal actions concerning Indians.

In Johnson v. McIntosh, ${ }^{\mathbf{6 8}}$ Chief Justice Marshall stated that the federal government had some sort of ownership interest in Indian land. In the first Cherokee Case, Cherokee Nation v. Georgia, ${ }^{59}$ discussed above, ${ }^{60}$ the Chief Justice had compared the federal government's relationship to Indian tribes to that of a guardian to its ward. ${ }^{61}$ Both Johnson and the Cherokee Cases were concerned with upholding federal supremacy in Indian affairs over states and individuals. The federal goal was to obtain cessions of land and to ensure peace with the tribes by promises of protection from outsiders meddling with Indian land or sovereignty. ${ }^{62}$ From these two concepts-property interest and guardianship-the Court in the late nineteenth century gradually developed a guardianship power over Indian tribes, which it frankly acknowledged to be extraconstitutional. ${ }^{63}$

\section{a. Genesis of Plenary Power: The Doctrine of Discovery}

The notion that the federal government had a property interest of some sort in Indian land provided the central analytical element for the guardianship power. Thus, to understand the guardianship power asserted by the federal government, it is necessary briefly to trace the history of the Doctrine of Discovery, the source of the property interest. Johnson v. McIntosh, ${ }^{64}$ decided in 1823, was the first major case directly concerning the validity of Indian property interests to reach the Court. ${ }^{65}$ Drawing inspiration from international law regarding the sov-

powers over the Commissioner of Indian Affairs were removed from the Secretary of War and given to the Secretary of the Interior. Act of Mar. 3, 1849, ch. 108, $\S 5,9$ Stat. 395.

B8 21 U.S. (8 Wheat.) 543 (1823).

so 30 U.S. (5 Pet.) 1 (1831).

${ }^{B 0}$ See supra notes $41-44$ and accompanying text.

6130 U.S. (5 Pet.) at 17.

62 See F. Prucha, supra note 13, at 44; cf. Worcester, 21 U.S. (8 Wheat.) at 555.

Bs See infra notes 64-102 and accompanying text.

6421 U.S. (8 Wheat.) 543 (1823).

6s In an earlier case, Chief Justice Marshall sidestepped the issue of validity of Indian property interests by stating that Indian property interest "which is certainly to 
ereign rights of the nations that discovered the New World, Chief Justice Marshall held that by virtue of discovering a nation inhabited by non-Europeans, the discovering nations (and America as their successor) obtained a property interest, described as "ultimate title," to that discovered land. ${ }^{86}$ According to Chief Justice Marshall: "[D]iscovery gave title to the government by whose subjects, or by whose authority, it was made, against all other European governments, which title might be consummated by possession." ${ }^{\prime 67}$ This title gave the government the preemptive right to purchase Indian land or confiscate it after a war. The Indians, on the other hand, remained "the rightful occupants of the soil, with a legal as well as just claim to retain possession of it." Until the sovereign exercised its preemptive right to extinguish Indian title, the Indians' right to the land was sacrosanct. Thus a purchaser from the Indians could not obtain a fee simple absolute title without obtaining the government's interest as well.

The Doctrine of Discovery protected federal, individual, and tribal interests. Federal power to control acquisition of new land was supreme. Individuals tracing title to past grants had their title confirmed, although if Indians still inhabited the land, extinguishment of the Indian title was necessary to perfect their interests. Finally, tribal rights to aboriginal land were confirmed and protected to some extent. ${ }^{69}$

Although the Doctrine of Discovery was a concept designed in part to protect Indian rights to land as well as to protect the principle

be respected by all courts, until it be legitimately extinguished, is not such as to be absolutely repugnant to seisin in fee" on the part of the state of Georgia, one of the original 13 States. Fletcher v. Peck, 10 U.S. (6 Cranch) 87, 142-43 (1810).

${ }^{68} 21$ U.S. (8 Wheat.) at 585.

67 Id. at 573 .

68 Id. at 574 .

69 See Cohen, Original Indian Title, 32 MiNN. L. REv. 28, 48-49 (1947); accord Barsh \& Henderson, Contrary Jurisprudence: Tribal Interests in Navigable Waterways Before and After Montana v. United States, 56 WASH. L. REv. 627, 635-36 (1981); Berman, The Concept of Aboriginal Rights in the Early Legal History of the United States, 27 Bufralo L. REv. 637, 644-45 (1978). See generally Henderson, Unraveling the Riddle of Aboriginal Title, 5 Am. Indan L. REv. 75 (1977).

The Doctrine of Discovery was a compromise of competing interests. If the Court held that the Indians had a fee simple title and thus could sell their land to anyone, two results would occur, both unfortunate from the standpoint of the government. First, many landowners traced their title back to land grants from Britain, France, and the federal government made while Indian tribes still occupied the soil. Thus, such a decision would unsettle the existing land titles resting on these past grants. Second, permitting private sales would destroy the federal government's ability to control the disposition of newly acquired land outside the 13 original states. On the other hand, to hold that Indians had no legal right to their land would have violated the many treaties and proclamations promising to protect their property rights. Such a result might have stripped future treaty negotiations of their credibility and increased the danger of Indian wars. 
of federal exclusivity in dealing with Indians regarding their land, later judicial misinterpretations of the doctrine are in large part responsible for arguments in favor of virtually unreviewable federal power over Indian lands. These arguments were prevalent in the late eighteenth and early nineteenth centuries and are still present to some extent in Indian law today.

While the early decisions of the Marshall Court viewed the government's property interest in land as a preemptive right to purchase, or a sort of glorified option to buy the land, subsequent decisions denominated the government's interest as a title interest and the tribal interest as a possessory one. ${ }^{70}$ The more the government's interest was characterized as an ownership interest, the more it became possible to regard the ownership of land alone as giving the government power to govern Indians. For example, an 1846 decision, United States $v$. Rogers, ${ }^{71}$ upheld, by reference to the government's ownership of the tribal land in question, a provision of the Trade and Intercourse Act of 1834 regulating criminal conduct on Indian land by Indians and non-Indi-

${ }^{70}$ It has been stated that in Johnson the Court held that the United States acquired fee simple absolute title to Indian land, e.g., 1982 HANDBOOK, supra note 3, at 209. Wording in the opinion supports this interpretation. Compare, e.g., 21 U.S. (8 Wheat.) 543, 548, 592 (describing United States interest as absolute dominion, ultimate title, and seisin) with, e.g., id. at 587, 603 (describing Indian interest as possessory). The actual holding in Johnson, however, established only a lesser interest: the exclusive right to acquire Indian property by purchase or conquest. 21 U.S. ( 8 Wheat.) at 585, 587,592 . In Worcester, the Court stated the government's interest did not enable it to give a clear title to a government grantee; such grants were "blank paper, so far as the rights of the natives were concerned." Worcester, 31 U.S. (6 Pet.) at 546. Again, the government's only right was a "pre-emptive privilege," $i d$. at 544; "the exclusive right of purchasing such lands as the natives were willing to sell," $i d$. at 545 . Such a limited right is not compatible with the notion of a fee simple interest in the government. In Mitchel v. United States, 34 U.S. (9 Pet.) 711,746 (1835), decided only twelve years after Worcester, the Court characterized the United States interest as an ultimate fee subject to a right of possession in the Indians to take effect only upon abandonment of the land by Indians or cession to the United States. See Berman, supra note 69, at 655, 666-67; Henderson, supra note 69, at 90-91.

Nevertheless, in recent years, the Court has interpreted these early cases as standing for the proposition that the United States gained a fee simple absolute title, leaving Indian tribes with no rights in their lands enforceable against the government, unless granted affirmatively by statute or treaty. Tee-Hit-Ton Indians v. United States, 348 U.S. 272 (1955). For an analysis of Tee-Hit-Ton and its effect on modern Indian law, see Newton, At the Whim of the Sovereign: Aboriginal Title Reconsidered, 31 HasTINGS L.J. 1215 (1980); see also infra text accompanying notes 299-314.

7145 U.S. (4 How.) 567 (1846) (construing Act of June 30, 1834, ch. 161, \& 25, 4 Stat. 729, 733 (current version at 18 U.S.C. $\$ 1152$ (1976)) ("That so much of the laws of the United States as provides for the punishment of crimes committed within any place within the sole and exclusive jurisdiction of the United States, shall be in force in the Indian country: Provided, The same shall not extend to crimes committed by one Indian against the person or property of another Indian."). For the legislative history and description of the 1834 Trade and Intercourse Act, see 1982 HANDBOOK, supra note 3 , at 115-17. 
ans. ${ }^{72}$ Although generally interpreted as relying on the property clause as a source of power ${ }^{73}$ the Rogers opinion is less important for its holding than for the broad language employed by the Court regarding the relationship of the Doctrine of Discovery to federal power to govern Indians. For instance, the Court referred to the Doctrine of Discovery as negating any ownership interest Indian tribes might have in their lands and subjecting the tribes to the political authority of the United States. ${ }^{74}$

This was essentially a misinterpretation of the doctrine. As discussed previously, the original concept of a discoverer's rights was far narrower, and did not include the right to govern internal affairs of Indian tribes. ${ }^{75}$ Moreover, whatever interest in ordinary reservation land the United States might have acquired through discovery, the United States had no such ownership interest in the Cherokee land involved in Rogers, because the tribe had obtained a United States patent granting a fee simple title to their land. ${ }^{76}$ Nevertheless, the Court took

${ }^{72}$ Trade and Intercourse Act of 1817, ch. 92, 3 Stat. 383 (repealed 1834).

7s The Court did not cite the property clause but stressed that the crime had been committed "within the territorial limits of the Unifed States . . . and not within the limits of one of the states." 45 U.S. (4 How.) at 572. The property clause of article IV grants to Congress the right "to dispose of and make all needful Rules and Regulations respecting the Territory or other Property belonging to the United States." U.S. CoNsT. art. IV, $\S 3$, cl. 2 . This language has been interpreted as granting Congress general jurisdiction over property located within the territories, but not property located within the borders of a state. See Engdahl, supra note 3, at 291-96.

As early as 1810 Chief Justice Marshall held that the property clause granted Congress broad power over the territories until they were ready for statehood: "The power of governing and of legislating for a territory is the inevitable consequence of the right to acquire and to hold territory." Sere v. Pitot, 10 U.S. (6 Cranch) 332, 336 (1810); cf. McCulloch v. Maryland, 17 U.S. (4 Wheat.) 316, 422 (1819) ("Yet all admit the constitutionality of a territorial government . . . ."). Later cases continued to uphold this power as inherent in sovereignty, plenary, and virtually "without limitations." See, e.g., American Ins. Co. v. Canter, 26 U.S. (1 Pet.) 511, 546 (1828) (recognizing a general right of sovereignty "which exists in the government, or in virtue of [the article IV property clause]"); see also United States v. Gratiot, 39 U.S. (14 Pet.) 526, 537 (1840) (article IV vests power in Congress "without limitation"). See generally Engdahl, supra note 3 (describing extent of article I and article IV property powers).

The property clause was relied on explicitly in some Indian law cases of the early twentieth century-especially those regarding liquor prohibitions. See Hallowell v. United States, 221 U.S. 317, 324 (1911) (property clause gives power to prohibit liquor on land held in trust); accord United States v. Celestine, 215 U.S. 278, 284 (1909). The Court never developed the property clause as a principle basis of congressional power, relying instead on the much broader guardianship power.

74 See 45 U.S. (4 How.) at 572.

${ }^{76}$ See supra notes $64-70$ and accompanying text.

${ }^{76}$ Although the treaty referred to a patent in fee simple, Treaty with the Cherokees at New Echota, Dec. 29, 1835, art. II, 7 Stat. 439, 441, the patent when issued contained a proviso that if the tribe ever abandoned the land or became extinct, title would revert to the United States. See Holden v. Joy, 84 U.S. (17 Wall.) 211, 246 
the occasion to characterize federal power as derived from its power over all Indian land and noted that the political question doctrine barred any inquiry into the justice of the government's exercising ultimate sovereignty over Indians. ${ }^{77}$

In addition, the Court's opinion undercut considerably the view of federal power and Indian sovereignty of the Cherokee Cases. ${ }^{78}$ The Court gave short shrift to the argument that the provision of the Trade and Intercourse Act at issue should be read in light of treaty promises to protect tribal self-government. ${ }^{79}$ Significantly, the Court for the first time indicated that federal power over Indian tribes need not be tied to treatymaking and execution, or regulation of commerce between Indians and outsiders.

Finally, Rogers is also important because the Court forthrightly accepted federal Indian legislation as being permissibly race-based. Rogers argued that the tribe had legally adopted him, thus bringing him within the law's exception for crimes committed by one Indian against another. The Court replied that the tribe's action in adopting Rogers could not change his race. The statutory exception applied only to members of the Indian race: "It does not speak of members of a tribe, but of the race generally-of the family of Indians . . . ."80

In sum, the analysis in Rogers became almost a paradigm of the judicial attitude toward Indian claims: emphasis on federal power coupled with references to the political question doctrine and disregard for both tribal sovereignty and individual rights.

(1872). Thus, the tribe did not actually receive a fee simple absolute title. Compare Cherokee Nation v. Southern Kan. Ry., 135 U.S. 641, 656 (1890) ("fee simple") (dicta) with Holden v. Joy, 84 U.S. (17 Wall.) at 250 (1872) ("fee simple subject to condition subsequent").

7745 U.S. (4 Wheat.) at 572.

${ }^{78}$ See supra notes 26-30 and accompanying text; see also, Clinton, Development of Criminal Jurisdiction Over Indian Lands: The Historical Perspective, 17 ARIz. L. REv. 951, 977-78 (1975) (Rogers undercut concept of Indian tribal sovereignty developed in Worcester).

79 In the Treaty with the Cherokees at New Echota, Dec. 29, 1835, art. V, 7 Stat. 478,442 , the United States had promised the Cherokee Nation to protect its right "to make and carry into effect all such laws as they may deem necessary for the government and protection of the persons and property within their own country." Id. In return, the Cherokee Nation promised that its laws would not conflict with the Constitution or federal laws "regulating trade and intercourse with the Indians." Id. The Court in Rogers found that the statute did not infringe on the treaty right of selfgovernment, because the provision in question was part of a Trade and Intercourse Act. 45 U.S. (4 Wheat.) at 573.

so 45 U.S. (4 How.) at 573. 


\section{b. Inherent Sovereignty and the Guardianship Role}

In 1883, in Ex parte Crow Dog, ${ }^{81}$ the Supreme Court overturned the conviction of a Sioux for the murder of another Sioux on the Sioux reservation. The facts of this case, characterized by the Court as an example of "red man's revenge," who saw Indians as barbaric ${ }^{\mathbf{8 3}}$ and no doubt fueled the arguments for rapid assimilation.

In response to the decision, Congress moved quickly in enacting the first of many pieces of assimilationist legislation, the Major Crimes Act. ${ }^{84}$ The law made federal offenses of seven major crimes if committed by Indians against Indians in Indian country, whether or not within the boundaries of any state. ${ }^{85}$

In 1886, the Court decided a challenge to the Major Crimes Act brought by a member of the Hoopa tribe charged with murdering another Indian on Hoopa land within the state of California. The Court acknowledged that the case, United States $v$. Kagama, ${ }^{86}$ presented two questions regarding federal power: whether Congress had the power to enact laws governing crimes committed by one Indian against another upon an Indian reservation and whether the law infringed upon state sovereignty. ${ }^{87}$ The Court quickly disposed of the first question by re-

81109 U.S. 556 (1883). At issue in Crow Dog was the same Trade and Intercourse Act provision upheld in Rogers. The statute, applying federal criminal law to non-Indians in Indian Country, expressly excepted crimes committed by Indians against Indians in Indian Country. See supra note 71.

The murder was a well-publicized one. When the Sioux Nation required only that the murderer support the victim's dependent relatives, the white community was outraged. See 1982 HANDBOOK, supra note 3, at 236. Crow Dog was subsequently arrested and convicted in the territorial court of Arkansas. The Supreme Court overturned the conviction, in the first case since Worcester to uphold tribal treaty rights. In reality, however, the Supreme Court merely upheld what it took to be the clear congressional intent expressed in the Trade and Intercourse Act against an argument that the statute had been repealed by implication. Though congressional power was not challenged, the Court indicated in dicta that congressional power within the borders of the states was limited to the powers to regulate commerce and effectuate treaties. 109 U.S. at 562 .

82109 U.S. at 571.

83 See Pancoast, The Indian Before the Law, in AMERICANIZING THE AMERICAN INDIANS, supra note 45, at 159-64 (criticism of lawless state on Indian reservations). Pancoast's indictment of the treaty policy of promising to protect Indian self-government was probably inspired in part by Crow Dog; he quoted from the opinion without citing it, perhaps because he regarded it as so notorious. See id. at 159 (quoting 109 U.S. at 568-69).

84 Act of Mar. 3, 1885, ch. 341, §9, 23 Stat. 362, 385 (codified as amended at 18

U.S.C. § $1153(1976))$.
85 Id.
Bs 118 U.S. 375 (1886).
${ }^{87} I d$. at $376-78$. 
casting it as a facet of the second. According to the Court, Indian tribes had limited authority over "internal and social relations" 88 because they were "semi-independent." and had not been considered sovereigns since the Cherokee Cases ${ }^{90}$ Any doubt about their sovereign status had been resolved by the 1871 statute outlawing treaties with Indian tribes-thenceforth Congress had determined "to govern them by acts of Congress." Moreover, the Constitution did not recognize Indian sovereignty; in fact the Constitution only recognized two sovereigns-the states and the federal government. The Court reasoned that since Indians were "within the geographical limits" of the United States, they must submit to one of these overriding sovereignties. ${ }^{92}$ The question thus became to which they must submit.

Having thus virtually established that any rights of Indian nations to self-government could be abrogated by a higher sovereignty, the Court went on to establish that the federal government, and not the states, had this ultimate authority. In seeking to justify this assertion of federal power, however, the Court had, through its earlier decisions, painted itself into a corner. In the first place, congressional power to regulate activities within the territories could not be invoked, because the land was within the state of California. ${ }^{93}$ Nor could the power to regulate Indian commerce be used, since at that time, the Court required a direct nexus with commerce to sustain federal laws regulating interstate and Indian commerce. ${ }^{94}$ The power to enact a criminal code applicable within the states, although fairly well-established today, was beyond the grant of power to regulate commerce with Indian tribes in 1885.95 Finally, the congressional power to effectuate treaties with In-
88 Id. at 382.
${ }^{80} \mathrm{Id}$. at 381 .
${ }^{90}$ Id. at 381-82.
o1 Id. at 382 .
92 Id. at 379.

${ }^{93}$ Compare, e.g., American Ins. Co. v. Canter, 26 U.S. (1 Pet.) 511 (1828) (congressional power over Florida territory upheld based on article IV) with Benner v. Porter, 50 U.S. (9 How.) 235 (1850) (territorial courts lack power over exclusive federal cases after statehood).

94 Like the interstate commerce clause, the Indian commerce clause was given a restrictive reading at this period, the Court requiring some sort of commercial nexus. Compare, e.g., United States v. Kagama, 118 U.S. 375, 378-79 (1886) and United States v. Bailey, 24 F. Cas. 937, 939 (C.C.D. Tenn. 1834) (No. 14,495) (Indian commerce clause limited to commercial intercourse) with, e.g., United States v. E.C. Knight Co., 156 U.S. 1 (1895) (commerce clause does not reach the manufacturing of sugar).

${ }^{85}$ [W] think it would be a very strained construction of this clause, that a system of criminal laws for Indians living peaceably in their reservations, which ... established punishments for the common-law crimes ... without any reference to their relation to any kind of commerce, was authorized by the grant of power to regulate commerce with the Indian 
dian tribes was similarly inapplicable, since no treaty was involved. ${ }^{96}$ Acknowledging that no existing constitutional provision granted Congress this right to govern Indian affairs, the Court found it to be inherent first by analogy to early decisions regarding the power to regulate activities within the territories. ${ }^{97}$ Drawing support from cases upholding congressional power to govern territories before statehood and language in United States $v$. Rogers relying on these same authorities, the Court in Kagama stated that the power over territories derived "from the ownership of the country in which the Territories are." The Court quoted an earlier opinion by Chief Justice Marshall regarding territorial government: "the right to govern may be the inevitable consequence of the right to acquire territory." the Court found inevitable the right to govern activities of reservation Indians whether within or without state boundaries. The Doctrine of Discovery gave the United States "ultimate title" over Indian land wherever located and the exclusive right to acquire that land. Thus the federal government owned the country in which the Indian tribes lived and this ownership interest in turn vested the government with the right to govern them. ${ }^{100}$

Finally, the Court relied on the history of federal supremacy over the states in Indian affairs and the historic, protective role the government played toward Indians:

These Indian tribes are the wards of the nation. They are communities dependent on the United States. Dependent largely for their daily food. Dependent for their political rights. They owe no allegiance to the States, and receive from them no protection. Because of the local ill feeling, the

tribes.

Kagama, 118 U.S. at $378-79$.

${ }_{98}$ The Hoopa tribe was one of the 119 California tribes or bands whose treaties had never been ratified by the Senate. See generally Goodrich, The Legal Status of the California Indian, 14 CALIF. L. REv. 83, 95-96 (1926) (California Indians surrendered aboriginal title to most of the state in 18 treaties in return for 7,500,000 acres, which they never received).

${ }^{87}$ In American Ins. Co. v. Canter, for example, Chief Justice Marshall had intimated that this power would exist even in the absence of article IV, because a contrary result would create a jurisdictional vacuum. 26 U.S. (1 Pet.) 511, 542 (1828).

os 118 U.S. at 380.

${ }^{99}$ Id. (quoting American Ins. Co. v. Canter, 26 U.S. (1 Pet.) 511, 542 (1828)).

100118 U.S. at 381-82. Having established federal power to legislate, the Court devoted the rest of its opinion to an analysis of the impact of this legislation on state sovereignty, holding that the Major Crimes Act did not abrogate state sovereignty to any alarming extent. Id. at 383-85. The law did not make criminal any activity the states regarded as legal. Moreover, states still had power to enforce their laws against non-Indians on Indian reservations. 
people of the States where they are found are often their deadliest enemies. From their very weakness and helplessness, so largely due to the course of dealing of the Federal Government with them and the treaties in which it has been promised, there arises the duty of protection, and with it the power. ${ }^{101}$

Thus, the Court upheld federal power over Indians for practical reasons. "It must exist in that government, because it never has existed anywhere else, because the theatre of its exercise is within the geographical limits of the United States, because it has never been denied, and because it alone can enforce its laws on all the tribes." 102

At first glance the practical solution seems a happy one. The states had proven themselves to be the greatest enemies of the Indian tribes, and the federal government had insisted on the exclusive right to deal with the tribes since the founding of the republic. Moreover, the practical solution did no violence to the allocation of powers between nation and states in the Constitution. ${ }^{103}$ Although the Court might have taken greater care to demonstrate that the continued power to legislate regarding Indian affairs was a necessary inference from the history and the text of the Constitution, still the narrow result of Kagama-the supremacy of federal over state power-was a just one.

Yet the Court in Kagama failed to consider tribal rights. Consent of the governed had been a cardinal principle of the founders. Nevertheless, that Indians were not citizens and could not vote did not seem relevant to the Court. Once again, by concentrating on justifying federal power the Court reinforced earlier precedents abdicating its role in accommodating the legitimate but competing interests raised by the federal government's interference with tribal rights. Such accommodation was left to the political arena-an arena from which Indians were excluded.

Kagama and its nineteenth century precedents reflect a laissezfaire judicial attitude toward federal regulation of Indian affairs more than a prescription concerning the proper balance of the interests at stake. It is unnecessary at this late date to argue that such a deferential

101 Id. at $383-84$

102 Id. at $384-85$.

103 The framers intended the federal government to have exclusive authority to deal with the Indians, partly because of the great need for a uniform policy to prevent Indian wars. They hardly can be faulted for not foreseeing the end of the treaty era or the day when no West would exist for the further removal of Indian tribes. Thus, the Indian commerce clause and the other general powers in the Constitution would have seemed to the framers "all that is required for the regulation of our intercourse with the Indians." Worcester v. Georgia, 31 U.S. (6 Pet.) 515, 559 (1832). 
attitude was inappropriate in nineteenth century jurisprudence, when nonintervention in the cause of individual liberties was a hallmark of judicial policy. ${ }^{104}$ What is important, however, is the tenaciousness of the deferential attitude, manifested in the Court's subsequent reliance on Kagama well into the twentieth century. These developments are considered next.

\section{From Aliens to Noncitizen Subjects: The Exercise of Plenary Power}

From the time of Kagama until well into the twentieth century, policymakers denied tribal Indians the basic freedoms accorded other Americans, on the theory that their relation to the United States was "an anomalous one and of a complex character." 108 Although nominally protected by the individual rights provisions of the Constitution like other noncitizens, ${ }^{108}$ during this period Indians and Indian tribes in fact could not vindicate their rights in the courts. While the fourteenth amendment had been held to guarantee all persons equal access to the state courts, irrespective of their race, ${ }^{107}$ Elk $v$. Wilkens ${ }^{\mathbf{1 0 8}}$ and subsequent cases cast considerable doubt on whether the fourteenth amendment's equal protection clause extended to Indians. ${ }^{109}$ Moreover,

104 See, e.g., Mormon Church v. United States, 136 U.S. 1, 44 (1890) (upholding law breaking up Mormon Church and providing for seizure of Church property); Dred Scott v. Sandford, 60 U.S. 393, 451-52 (1857) (fundamental property rights of slave owners); cf. Nelson, The Impact of the Antislavery Movement Upon Styles of Judicial Reasoning in Nineteenth Century America, 87 HaRv. L. REv. 513 (1974) (the formalistic "rules" approach of the late nineteenth century was in part a reaction to freewheeling instrumentalist opinions like Dred Scott).

${ }^{105}$ Kagama, 118 U.S. at 381.

${ }^{106}$ See, e.g., Wong Wing v. United States, 163 U.S. 228 (1896) (fifth and sixth amendments); Yick Wo v. Hopkins, 118 U.S. 356 (1886) (fourteenth amendment). These cases concerned Chinese aliens and not Indians. The extent to which the fourteenth amendment applied to bar discrimination by states against Indians is not at all clear.

107 Yick Wo v. Hopkins, 118 U.S. 356 (1886).

108112 U.S. 94 (1884).

${ }_{108}$ In United States v. Wong Kim Ark, 169 U.S. 649 (1898), a case involving a Chinese person claiming citizenship by birth in the United States, the Court reaffirmed the holding in Elk that tribal Indians were not citizens by birth because they were not subject to United States jurisdiction. Id. at 680-82 (dictum). More important, however, is the Court's comparison of the meaning of the phrases "subject to the jurisdiction" of the United States in the first sentence of section 1 of the fourteenth amendment and "within its jurisdiction" in the equal protection clause's injunction against the state denials "to any person within its jurisdiction the equal protection of the laws." U.S. CoNST. amend. XIV. The Court held that the two clauses had the same meaning. Thus, an alien could not be subject to United States jurisdiction and not be within state jurisdiction, nor within state jurisdiction and not simultaneously subject to United States jurisdiction. 169 U.S. at 687 . At the very least, such reasoning must have raised doubts about the equal protection rights of tribal Indians: in Elk the Court had held 
the 1866 Civil Rights Act guarantee that "citizens . . . shall have the same right . . . to sue, be parties, and give evidence"110 explicitly excluded Indians from citizenship. Even when access to the courts was granted, lack of familiarity with state law and procedures, state laws excluding them from juries and declaring them incompetent as witnesses, and state juries' anti-Indian prejudice were powerful disincentives to suit in state courts. ${ }^{111}$

Access to federal courts was also problematic. First, being neither citizens nor true aliens, individual Indians and Indian tribes could not sue in federal court on nonfederal questions. ${ }^{112}$ Although Indian tribes and individuals bringing class actions on behalf of tribes ${ }^{113}$ did raise federal questions in federal courts, their status as wards of the government sometimes confused the issue of tribal and individual standing to sue. $^{114}$

The most serious obstacle in federal court, however, was the doctrine of sovereign immunity. ${ }^{115}$ The federal statute creating the Court of Claims in 1863 specifically excepted claims arising out of treaty obli-

tribal Indians were not "subject to the jurisdiction of the United States" within the meaning of section 1. 112 U.S. at 102. Thus, tribal Indians might not have been within state jurisdiction for the purposes of equal protection. Perhaps the lack of any Indian challenge to state discriminatory laws during this period reflected a belief that no such claim could be successfully made.

110 Civil Rights Act of 1866, ch. 31, \& 1, 14 Stat. 27 (superseded 1940).

11 See 1982 HANDBOOK, supra note 3, at 645-51; Clinton \& Hotopp, supra note 13, at 46-47. For criticisms of Indians' legal disabilities made during the plenary power era, see Harsha, Law for the Indians, in AMERICANIzING THE AMERICAN INDIANS, supra note 45, at 149, 152 (1882 article) and Pancoast, The Indian Before the Law, in id. at 155,158 (1884 article).

112 See, e.g., Karrahoo v. Adams, 14 F. Cas. 134 (C.C.D. Kan. 1870) (No. 7,614) (Indians are not foreign citizens (relying on Cherokee Nation v. Georgia, 30 U.S. (5 Pet.) 1 (1831)), therefore, federal court has no jurisdiction over ejectment action brought by an Indian against a non-Indian); see also F. COHEN, HANDBOOK OF FEDERAL INDIAN LAw 372 (1942); $c f$. Felix v. Patrick, 145 U.S. 317, 332 (1892) (tribal Indians are not citizens capable of suing as such in federal courts) (dictum).

113 See, e.g., Lane v. Pueblo of Santa Rosa, 249 U.S. 110, 113-14 (1919) (tribal suit); Lone Wolf v. Hitchcock, 187 U.S. 553 (1903) (class action); Cherokee Nation v. Hitchcock, 187 U.S. 294 (1902) (tribal suit); cf. Fellows v. Blacksmith, 60 U.S. (19 How.) 366 (1856) (individual Indian sued to protect tribal property rights in state court).

114 Although the weight of authority supports individual standing to sue in federal court, see F. CoHEN, supra note 112, at 372-73, the Court in 1912 intimated that absent congressional permission, Indian owners of allotted land had no standing to sue on their own behalf to protect their land. Heckman v. United States, 224 U.S. 413, 438-44 (1912). See infra text accompanying notes 179-81.

116 Compare, e.g., Morrison v. Work, 266 U.S. 481, 486 (1925) and Naganab v. Hitchcock, 202 U.S. 473, 476 (1906) (sovereign immunity barred suits raising due process and breach of trust claims against the Secretary of Interior arising out of cession of timber lands in trust) with, e.g., Choctaw Nation v. United States, 119 U.S. 1, 2, 29 (1886) (jurisdictional statute permitted suit). 
gations from the new court's jurisdiction over claims for money damages against the United States. ${ }^{116}$ This exception was interpreted as including claims raising constitutional issues. ${ }^{117}$ Thus, tribes whose land had been taken in violation of a treaty had to lobby Congress for legislation granting jurisdiction to the Court of Claims and waiving sovereign immunity for the particular claims. ${ }^{118}$

Although tribes could seek injunctive relief in district court, for constitutional violations by federal officials, this remedy also proved elusive when the federal government was the defendant, for the Court often invoked the political question doctrine in declining to address the merits of these claims. ${ }^{119}$ When the merits were addressed, the Court, by feats of analytical legerdemain, alternately invoked the seemingly incompatible semisovereign status of Indian tribes and the guardianward relationship of Kagama as rationales for allowing the exercise of plenary power to deny tribal or individual rights.

Undoubtedly, racial and cultural prejudice played no small role in federal actions toward Indians during this period. The reported justifications for these federal actions rested on the guardianship theory of United States $v$. Kagama, cited frequently in the cases of that era. ${ }^{120}$ Yet one key to the Court's finding of a congressional guardianship power over Indians was its view of their racial and cultural inferiority. Repeatedly, the decisions of that era invoked this inferiority in terms that would be intolerable in a judicial opinion today. In a recent article, a commentator canvassed the cases of this era and reported a high instance of such derogatory language:

The undisguised contempt for the native culture was unrelieved by an open-minded assessment in any of the principal cases studied. Rather, the Indians were described as semi-barbarous, savage, primitive, degraded, and ignorant.

116 Act of Mar. 3, 1863, ch. 92, 12 Stat. 765 (codified as amended in scattered sections of 28 U.S.C.).

${ }^{117}$ See Hughes, Can the Trustee Be Sued for Its Breach? The Sad Saga of United States v. Mitchell, 26 S.D.L. REv. 447, 461-62 n.108 (1981).

118 See F. CoHEN, supra note 112, at 373-78; see also Cohen, Indian Claims, in The Legal Conscience 264 (L. Cohen ed. 1960); Wilkinson, Indian Tribal Claims Before the Court of Claims, 55 GEo. L.J. 511, 512 (1966).

118 See, e.g., Lone Wolf v. Hitchcock, 187 U.S. 553, 565 (1903) (injunction against allotment of tribal land in violation of treaty denied); Cherokee Nation v. Hitchcock, 187 U.S. 294, 308 (1902) (injunction against leasing of mineral rights without consent of the tribe denied; exercise of congressional power purely "political and administrative" and not open to question); $c f$. Lane v. Pueblo of Santa Rosa, 249 U.S. 110 (1919) (attempted allotment of fee simple tribal land; political question doctrine inapplicable since agency action was not authorized by Congress).

120 See infra note 145 and accompanying text. 
The relationship between the federal government and the Indian was frequently termed as one between a superior and inferior. The white race was called more intelligent and highly developed. There was no question but that a higher civilization was thought to be justly replacing that of a passing race whose time was over and whose existence could no longer be justified. The very weakness of the Indians in resisting the tide seemed to be one of their greatest moral shortcomings, but not as serious as the Indian communal tradition. To the white observer, the lack of proprietary interest generally displayed by tribal members was repulsive and backward. Removing the "herd" instinct was deemed by some to be the key to civilizing the Indian. ${ }^{121}$

The ethnocentric outlook of the times may well have tainted the Court's view of the legitimacy of Indian rights claims and may explain, if not excuse, some of the more egregious violations of tribal and individual fundamental rights detailed below.

\section{a. Tribal Rights to Property}

Forced allotment of Indian lands and assimilation of Indians into the dominant culture became the primary policy of the federal government during the years following Kagama. ${ }^{122}$ Tribal land was subdivided, some apportioned to individuals with no compensation to the tribe, and the rest sold to non-Indian settlers, ${ }^{123}$ often at far less than fair market value. ${ }^{124}$ The Court aided this process, holding that the

121 Carter, Race and Power Politics as Aspects of Federal Guardianship over American Indians: Land-Related Cases, 1887-1924, 4 AM. IndiAN L. Rev. 197, 227 (1976) (citations omitted); see also Note, Constitutional Law: Congressional Plenary Power over Indian Affairs-A Doctrine Rooted in Prejudice, 10 Am. Indian L. Rev. 117 (1982).

122 See, e.g., Monson v. Simonson, 231 U.S. 341, 345 (1913) (dictum); United States v. Rickert, 188 U.S. 432, 437 (1903) (dictum); see also R. BERKHOFER, JR., supra note 19, at 166-75; S. TYLER, supra note 19, at 95-124.

123 Although allotment had been accomplished by consent, or at least a show of consent, before the plenary power era, during the height of the allotment fever, Congress enacted statutes permitting allotment without tribal consent. See, e.g., Act of June 17, 1892, 27 Stat. 52 (requiring allotment and opening reservation to settlement), discussed in Mattz v. Arnett, 412 U.S. 481, 494-506 (1973). For descriptions of methods of allotment used, see 1982 HANDBOOK, supra note 3, at 129-37; F. CoHEN, supra note 112 , at $427-28$.

124 See, e.g., Creek Nation v. United States, 97 Ct. Cl. 591 (1942) (no clear and convincing evidence of fraud or gross mistake; therefore, no recovery for tribe protesting appraisals made pursuant to 1901 agreement which were at most one-half of the price of the same parcels sold at public auction one year later), aff'd, 318 U.S. 629 (1943); cf. Yankton Sioux Tribe v. United States, 623 F.2d 159 (Ct. Cl. 1980) (consideration 
plenary power of Congress, derived from the Indians' "condition of dependency,"125 somehow converted Indian property, even fee simple property, into quasi-public land "subject to the administrative control of the government."126 This authority permitted Congress, acting through the Secretary of the Interior, to lease, sell, or allot any tribal land without tribal consent, even in violation of solemn treaty promises. ${ }^{127}$ The money gained by these ventures was placed in trust funds managed by the government and disbursed as the government believed wisest, often for the purpose of assimilating and civilizing the Indians. ${ }^{128}$ For example, tribal trust money was often spent to pay mis-

paid by the United States to the tribe for surplus land which the United States later sold to settlers was unconscionable, because the United States paid $\$ 600,000$ for land worth $\$ 1,337,381.50$ ).

${ }^{125}$ Stephens v. Cherokee Nation, 174 U.S. 445, 488 (1899).

128 Cherokee Nation v. Hitchcock, 187 U.S. 294, 308 (1902). The Cherokee Nation held patents granting the tribe a fee simple interest in tribal property. See supra note 76. Nevertheless, the Court upheld congressional power to lease Cherokee land without consent, as exercised in the Curtis Act of 1898. Act of June 28,1898, ch. 517, 30 Stat. 495. A few months before Hitchcock was decided, the Cherokee Nation had formally consented to the provisions of the Curtis Act, including the provisions regarding leasing challenged in the Hitchcock case. The tribe probably acquiesced in the Curtis Act because it had no other choice. In Stephens v. Cherokee Nation, 174 U.S. 445 (1899), the Court had upheld the constitutionality of the Curtis Act even though the issues in that case were not affected by that act, stating: "The lands and moneys of these tribes are public lands and public moneys . . . " Id. at 488.

Pueblo land was also fee simple land. See United States v. Candelaria, 271 U.S. 432,440 (1926). Nevertheless, guardianship power was extended to this land. In Candelaria, the Court held that the Nonintercourse Act, discussed supra notes 24-25 and accompanying text, imposed restrictions against alienation on all Indian tribes, and thus on all tribal land, including fee simple land. Furthermore, the Court held that this restriction on alienation created a guardianship over all Indian lands, giving the government powers regarding the land, including standing to sue on behalf of the Pueblos to quiet title, at issue in the Candelaria case. 271 U.S. at 440-44. Although stated in the context of a decision upholding federal power to help the Pueblos, this reasoning permitted extension of all congressional guardianship powers to the Pueblos. $C f$. United States v. Sandoval, 231 U.S. 28, 45-46 (1913) (guardianship power permits statute outlawing sale of liquor to Pueblos) ("United States as a superior and civilized nation [has] the power and the duty of exercising a fostering care and protection over all dependent Indian communities . . . .").

${ }^{227}$ See, e.g., Lone Wolf v. Hitchcock, 187 U.S. 553 (1903) (forced allotment in violation of treaty); Cherokee Nation v. Hitchcock, 187 U.S. 294 (1902) (leasing); $c f$. Morrison v. Fall, 290 F. 306 (D.C. Cir. 1923), aff'd sub nom. Morrison v. Work, 266 U.S. 481 (1925) (Tribe ceded timber land in trust to government to sell and hold proceeds in trust for tribe. The government later granted 600,000 acres of the land to the State of Minnesota for a forest preserve without compensating the tribe. The court dismissed the claim because the state, an indispensable party, had not been joined. The court dismissed the tribe's other claims regarding handling of the timber land because sovereign immunity had not been waived.). See generally 1982 HANDBOoK, supra note 3 , at 516 .

${ }^{128}$ General Allotment Act of 1887, ch. 119, § 5, 24 Stat. 388, 389-90 (codified as amended at 25 U.S.C. $\S 348$ (1976)) (Congress could appropriate trust money derived from sale of surplus lands for civilizing the Indians). 
sionaries to educate Indian children in the ways of white society and Christianity-without consulting the tribe. ${ }^{\mathbf{1 2 9}}$ Furthermore, money promised the tribe as an entity in treaties could be paid to members per capita, thus drastically diminishing the tribe's resources. ${ }^{130}$

The Court supported these federal actions by eschewing any role in accommodating the competing interests at stake. In Lone Wolf $v$. Hitchcock, ${ }^{131}$ which has been called "the Indians' Dred Scott decision,"132 the Court sustained an allotment act against a twofold challenge: first, that the allotment process violated a treaty barring allotment without the consent of three-fourths of the adult male tribal members; second, that the statute enacted to effectuate the illegal treaty violated due process of law. ${ }^{133}$ The Court dismissed the tribe's treaty claim, ruling that the last-in-time rule permitted congressional abrogation of treaties. ${ }^{134}$ As to the tribe's fifth amendment claim, the Court explicitly adopted the reasoning of Kagama. ${ }^{135}$ Congress had decided in 1871 to govern Indians by statute and its actions were not justiciable: "Plenary authority over the tribal relations of the Indians has been exercised by Congress from the beginning, and the power has always

120 The widespread practice of paying religious institutions to educate Indian children had caused great controversy. See Quick Bear v. Leupp, 210 U.S. 50, 78-79 (1908); see also R. BERKHOFER, JR., supra note 19, at 149-51. In Quick Bear, the Court upheld payment to a religious institution of tribal trust money from a fund established for education of Indian children against a claim that the practice violated a federal statute prohibiting expenditure of public money for sectarian schools. Members of the tribe had brought a class action to protest the payments, which were supported by other members of the tribe. Thus, no tribal rights were argued in the case. The Court reasoned that the statute did not apply to the funds, because tribal trust money is not public money, but private money, "or at least is dealt with by the government as if it belonged to them, as morally it does." Quick Bear, 210 U.S. at 80 (emphasis added). The Court in Quick Bear may have been influenced by the fact that 212 members of the tribe had petitioned for the money to be paid to the mission school. Id. at $70 \mathrm{n} .1$ (answer of government to complaint). The Court stressed the rights of individual Indians "to use their own money to educate their children in the schools of their own choice." Id. at 81. Only a few years before Quick Bear, however, the Court had stated unequivocally: "The lands and moneys of these tribes are public lands and public moneys, and are not held in individual ownership ...." Stephens v. Cherokee Nation, 174 U.S. 445,488 (1899). Thus, the very status of Indian property and money shifted depending on the Court's vision of the federal policy to be furthered in a given case.

1so See, e.g., Act of Mar. 2, 1907, ch. 2523, 34 Stat. 1221 (codified as amended at 25 U.S.C. $\S \S 119,121$ (1976) (authorizing Secretary of Interior to pay individual Indians a pro rata share of tribal or trust funds)), discussed in Yankton Sioux Tribe v. United States, 623 F.2d 159, 180-81 (Ct. Cl. 1980). See generally F. CoHEN, supra note 112 , at $341 \&$ n.615.

191187 U.S. 553 (1903).

132 Sioux Nation v. United States, 601 F.2d 1157, 1173 (Ct. Cl. 1979) (Nichols, J., concurring), affd, 448 U.S. 371 (1980).

${ }^{133}$ Lone Wolf, 187 U.S. at 561.

134 Id. at 566 .

135 Id. at 567 (quoting Kagama, 118 U.S. at 383-85). 
been deemed a political one, not subject to be controlled by the judicial department of the government."136

Kagama and Lone Wolf became the linchpins of the plenary power doctrine. Congressional power over property, justified as a guardian's power, seemed subject to no judicial limitations. Apart from Lone Wolf and a few other cases, ${ }^{137}$ Indians abandoned the attempt to restrain federal action. Instead, tribes used what resources they had to persuade Congress to pass statutes permitting them to sue for compensation for land that was taken. ${ }^{\mathbf{1 3 8}}$

\section{b. Tribal Rights to Political Autonomy}

The legacy of Kagama dominated Indian sovereignty issues, and citation of Kagama frequently signaled judicial deference to Congress. ${ }^{130}$ Chief Justice John Marshall had regarded Indian tribes as possessing a "right of self-government"140 and having a protectorate relationship with the federal government, like "that of a nation claiming and receiving the protection of one more powerful: not . . . submitting as subjects to the laws of a master."141 Nevertheless, in Kagama, the Court interpreted the 1871 statute ending the practice of making treaties with Indian tribes ${ }^{\mathbf{1 4 2}}$ as establishing the premise that the federal government intended "to govern [Indian tribes] by acts of Congress."143 Thus, the Court upheld federal power to take from Indian tribes jurisdiction over crimes among Indians, the first major federal inroad into tribal internal affairs. ${ }^{144}$ The court subsequently invoked the Kagama

${ }^{136}$ Id. at 565.

137 See Naganab v. Hitchcock, 202 U.S. 473 (1906) (sovereign immunity barred suit); Cherokee Nation v. Hitchcock, 187 U.S. 294 (1902) (leasing powers upheld); Cherokee Nation v. Southern Kan. Ry. Co., 135 U.S. 641 (1890) (grant of railroad right of way without tribal consent upheld).

138 See generally Wilkinson, supra note 118 , at 513-18 (history of difficulties pressing claims under special jurisdictional acts).

${ }_{130}$ See, e.g., United States v. Sandoval, 231 U.S. 28, 46 (1913) (quoting Kagama in upholding congressional power to regulate introduction of liquor into Indian land); Stephens v. Cherokee Nation, 174 U.S. 445, 485-86 (1899) (quoting Kagama in upholding congressional power to determine tribal membership). The Court even relied on Kagama and plenary power when much narrower grounds existed to justify federal actions. See, e.g., Wallace v. Adams, 204 U.S. 415, 423 (1907) (plenary power invoked despite existence of tribal consent); Cherokee Nation v. Southern Kan. Ry. Co., 135 U.S. 641, 655 (1890) (Kagama quoted in a case upholding congressional power to take Indian land for a public use upon payment of compensation).

140 Worcester v. Georgia, 31 U.S. (6 Pet.) 515, 556 (1832).

141 Id. at 555.

142 See supra note 23.

143 Kagama, 118 U.S. at 382.

144 See Clinton, supra note 78, at 962-65. According to Professor Clinton, the Federal Major Crimes Act conflicted not only with "the spirit of almost every treaty 
guardianship power and the political question doctrine as justifying judicial nonintervention when Congress abrogated tribal self-government rights. ${ }^{145}$ Tribes largely shunned litigation as a strategy to protect their political sovereignty interests after these early judicial defeats. ${ }^{146}$

Having obtained such a judicial seal of approval for the exercise of its power, Congress proceeded to treat the previously semi-independent Indian tribes as subject peoples. ${ }^{147}$ The dissolution of tribal governing structures was a cardinal aim of the Allotment Period. ${ }^{148}$ For instance, in 1906, Congress denied the legislatures of the Five Civilized Tribes the right to meet more than thirty days per year, and their legislative action was made subject to veto by the President of the United States. ${ }^{148}$ Legislative intervention even extended to federal power over

negotiated during the treaty period but was also in plain conflict with the treaty provisions by which the United States had guaranteed certain tribes, including the Five Civilized Tribes, exclusive power to govern intratribal matters and to punish intratribal crimes." Id. at 965 n.76.

145 See, e.g., United States v. Sandoval, 231 U.S. 28, 46 (1913) (quoting Kagama in upholding imposition of liquor prohibition in Pueblo Indians); United States v. Celestine, 215 U.S. 278, 290 (1909) (invoking political question doctrine in applying Major Crimes Act to Indian who had become a United States and state citizen upon receiving allotted land within a reservation); Cherokee Nation v. Hitchcock, 187 U.S. 294, 308 (1902) (invoking political question doctrine in upholding Curtis Act provisions permitting leasing without tribal consent); Stephens v. Cherokee Nation, 174 U.S. 445,485 (1899) (invoking political question doctrine and quoting Kagama in upholding congressional power to determine membership in tribe).

${ }_{148}$ See supra notes 137-38 and accompanying text.

147 Frequently the Court referred to the relationship between the federal government and tribal Indians and Indian tribes as "that between a superior and inferior, whereby the latter is placed under the care and control of the former." Choctaw Nation v. United States, 119 U.S. 1, 28 (1886), quoted in, e.g., United States v. Rickert, 188 U.S. 432, 443 (1903). See generally R. BERKHOFER, JR., supra note 19, at 166-75.

148 See, e.g., 1982 HANDBook, supra note 3, at 131 \& n.39; S. TYLER, supra note 19, at 95-96 (quoting Annual Report of the Board of Indian Commissioners for 1888). Many cases of that era referred to the policy of dissolving tribal structures. See, e.g., United States v. Nice, 241 U.S. 591, 596 (1916) (allotment of Sioux land under General Allotment Act of 1887); Goat v. United States, 224 U.S. 458, 464 (1912) (Seminole allotment); Mullen v. United States, 224 U.S. 448, 451 (1912) (Choctaw allotment).

149 Five Tribes Act of 1906 , ch. 1876, $\S 28,34$ Stat. 137, 148. The Five Civilized Tribes living in Indian Territory had been excluded from earlier allotment legislation, but a congressional commission known as the Dawes Commission, headed by former Senator Dawes who had introduced the General Allotment Act of 1887, recommended these remaining tribes be broken up. See Dawes, The Indians of the Indian Territory, in AMERICANIZING THE AMERICAN INDIANS, supra note 45, at 317. Senator Dawes spoke openly of the fine coal reserves on Indian land which "must be worked by white men who understand the business," $i d$. at 323, and of the needs of the 300,000 whites who then lived in Indian territory occupied by only 50,000 Indians, id. at 324-25.

For a comprehensive review of the attempted dismantling of the Five Civilized Tribes, and in particular of the legislation affecting Creek tribal government, see Harjo v. Kleppe, 420 F. Supp. 1110, 1118-34 (D.D.C. 1976), affd sub nom. Harjo v. Andrus, 581 F.2d 949 (D.C. Cir. 1978). 
tribal money. Statutes provided that money due to tribes from tribal assets could be appropriated at the discretion of Congress. ${ }^{150}$ The Secretary of the Interior's power over disbursement of Indian money ${ }^{151}$ enabled him to manipulate the tribe with a concomitant weakening effect on tribal sovereignty. Moreover, Congress, not the tribes, had the ultimate authority to determine who was a tribal member for purposes of distributing property, annuities, and trust money, ${ }^{\mathbf{1 5 2}}$ and how that money was spent. ${ }^{163}$ Finally, Congress even authorized the consolidation of tribes with no ethnological ties ${ }^{154}$-_even some who were ancient enemies. ${ }^{185}$

As one commentator has noted, by these and other measures, "the Indian Agent and his staff were 'the government' for most tribes from the cessation of treaty-making to the 1930's."156 While the courts did not explicitly endorse every erosion of tribal political sovereignty occurring during this time, they certainly shared responsibility for it, because Kagama and its progeny had eviscerated any litigation strategy to protect tribal sovereignty rights.

\section{c. Individual Citizenship and Voting Rights}

Judicial abandonment of Indians was not limited to rights asserted by tribes. The Court also treated individual Indians as constitutional castaways. For instance, according to Kagama, Indians were within the geographical limits of the United States and thus subject to whatever laws Congress deemed appropriate. ${ }^{187} \mathrm{~A}$ year and a half before Kagama, however, the Court had held in Elk v. Wilkins ${ }^{\mathbf{1 5 8}}$ that Indians were not citizens, thereby upholding a state's denial of the right to vote to an Indian who had severed relations with his tribe and become a lawful resident of the state. Over the dissent of the first Mr. Justice Harlan, the Court reasoned that, although the petitioner was born in

150 For a collection of these statutes, see F. CoHEN, supra note 112, at 341.

181 See 1982 HANDBOOK, supra note 3, at 138-39.

182 "The power of Congress over the matter of citizenship in these Indian tribes was plenary, and it could adopt any reasonable means to ascertain who were entitled to its privileges." Wallace v. Adams, 204 U.S. 415, 423 (1907) (construing Stephens v. Cherokee Nation, 174 U.S. 445 (1899)). See generally F. CoHEN, supra note 112, at 341.

18s See supra note 150 and accompanying text.

164 See 1982 HandBoor, supra note 3, at 5-6.

155 See, e.g., Act of June 7, 1897, ch. 3, § 12, 30 Stat. 62, 93, 94 (authorizing occupancy of Shoshone land by Arapahos, long-time foes of the Shoshone Tribe), discussed in Shoshone Tribe v. United States, 299 U.S. 476, 489 (1937). See generally 1982 HANDBOOK, supra note 3, at 6-7.

186 T. Taylor, The States and Their Indian Gitizens 17 (1972).

187 Kagama, 118 U.S. at 381.

158112 U.S. 94 (1884). 
the United States, he was not "subject to the jurisdiction" of the United States for the purposes of the fourteenth amendment, ${ }^{159}$ because all Indians "owed immediate allegiance to their several tribes, and were not part of the people of the United States."160 Indians might be subject to United States jurisdiction in some respects, but the fourteenth amendment required more: they must be "completely subject to [United States] political jurisdiction, and owing them direct and immediate allegiance. ${ }^{\text {1161 }}$

While the Court in Elk reaffirmed salutary principles of tribal sovereignty, it undermined individual rights, because Indians, even those who had assimilated, could not become citizens of the United States without permission of Congress. ${ }^{162}$ Many other noncitizen aliens who owed direct allegiance to another nation had a choice Indians never had: they could go home and remain subject to the sole jurisdiction of the country of their birth. Indians, on the other hand, were alien subjects of a federal power they had not chosen and could not escape.

Eventually those who favored the assimilationist policy because of concerns for Indian well-being urged successfully that Indians who received allotments be made United States citizens. ${ }^{163}$ The grant of citi-

158 U.S. CoNST. amend. XIV, $\S 1$ ("All persons born or naturalized in the United States, and subject to the jurisdiction thereof, are citizens of the United States and of the State wherein they reside.").

160112 U.S. at 99.

${ }_{162} I d$. at 102 . The Court bolstered this conclusion by referring to provisions excluding "Indians not taxed" in both the article I and the fourteenth amendment apportionment clauses as providing further textual authority that Indians were "never deemed citizens." Id. at 100,102. According to the Court, since Indians were not taxed, they formed "no part of the people entitled to representation." Id. at 103. Today, Indian tribes and tribal Indians are immune from state taxes on "Indian reservation lands or Indian income from activities carried on within the boundaries of the reservation . . absent congressional consent." Mescalero Apache Tribe v. Jones, 411 U.S. 145, 148 (1973) (dictum) (citing McClanahan v. Arizona State Tax Comm'n, 411 U.S. 164 (1973)). Nevertheless they are subject to federal taxes and to state taxes for activities taking place off-reservation and for certain activities on-reservation involving Indians and non-Indians. Compare, e.g., $i d$. (state gross receipts tax on ski resort operated on federal land off-reservation permissible) with White Mountain Apache Tribe v. Bracker, 448 U.S. 136 (1980) (state motor carrier license and use-fuel tax imposed on nonIndian company employed by tribe to aid in tribal logging operation impermissible because preempted by federal regulations embodying the policy of preserving profits from logging industry for tribe). The phrase "Indians not taxed" has no relevance today, because Indians are now citizens who vote, pay taxes, and are counted for apportionment purposes. See generally 1982 HaNDBOOK, supra note 3, at 389.

162 See Elk, 112 U.S. at 100.

${ }_{103}$ The General Allotment Act provided that Indians receiving allotments under any treaty or statute would become citizens, General Allotment Act of 1887 , ch. 119, $\S$ 6, 24 Stat. 388,390 (codified as amended at 25 U.S.C. $\$ 349(1976)$ ). The act also declared Indians living separate and apart and "adopting the habits of civilized life" to be citizens. Id. See generally F. CoHEN, supra note 112, at 154; Pancoast, The Indian Before the Law, in AMERICANIzING THE AMERICAN INDIANS, supra note 45, at 158-66 
zenship permitted Indians to take part in the political process. Nevertheless, those Indians whose lands escaped allotment remained noncitizen subjects.

Even after the bestowal of citizenship on all Indians, ${ }^{164}$ Congress continued to legislate pervasively on Indian matters. The Court supported this exercise of power, holding that conferral of citizenship did not end the guardian-ward relationship. ${ }^{\mathbf{1 6 5}}$ Moreover, the Court held that an individual Indian had no power to terminate the guardian-ward relationship unilaterally: "It rests with Congress to determine the time and extent of emancipation."168

\section{d. Individual Rights}

Legislation of this era curtailed individual Indian property rights by placing restraints on the alienation of allotted land, ${ }^{167}$ including fee simple allotted land. ${ }^{168}$ The right of Indians to make contracts affecting

(advocating citizenship).

164 Indian Citizenship Act of 1924, ch. 233, 43 Stat. 253 (current version at 8 U.S.C. § 1401(b) (1982)).

${ }_{185}$ See, e.g., Cramer v. United States, 261 U.S. 219, 232 (1923); United States v. Celestine, 215 U.S. 278, 290-91 (1909); Mosier v. United States, 198 F. 54, 57 (8th Cir. 1912).

188 United States v. Waller, 243 U.S. 452, 459 (1917); see also United States v. Sandoval, 231 U.S. 28, 46 (1913) (quoting Tiger v. Western Investment Co., 221 U.S. 286, 315 (1911)).

107 The General Allotment Act imposed a restriction on alienation of land allotted under its provisions until the issuance of a patent in fee after 25 years. General Allotment Act of 1887 , ch. $119, \S 5,24$ Stat. $388-89$ (codified as amended at 25 U.S.C. $\S$ 348 (1976)), construed in, e.g., Monson v. Simonson, 231 U.S. 341, 345-46 (1913); see also The Indian Homestead Act of 1884, ch. 180, § 1, 23 Stat. 76, 96 (imposing a restriction on alienation for 25 years) (repealed 1976). The restrictions on alienation were frequently extended by executive order, as permitted by the General Allotment Act of 1887, ch. 119, $\S 5,24$ Stat. 389 (codified as amended at 25 U.S.C. $\S 348$ (1976)), construed in United States v. Reynolds, 250 U.S. 104 (1919), and the Act of June 21, 1906, 34 Stat. 326 (permitting such extension for all land allotted under treaties or statutes), construed in United States v. Jackson, 280 U.S. 183, 189-91 (1930). Leasing allotted land without approval was also barred by various laws. See, e.g., The Osage Allotment Act of 1906, ch. 3572, \& 7, 34 Stat. 545, construed in LaMotte v. United States, 254 U.S. 570, 575-77 (1921); Act of Mar. 3, 1921, ch. 119, § 26, 41 Stat. 1248 (authorizing the Secretary to lease allotted Quapaw land for mining), construed in Whitebird v. Eagle-Picher Lead Co., 28 F.2d 200, 204 (N.D. Okla. 1928).

${ }_{168}$ Most tribal land was allotted by means of so-called "trust patents," with the United States government as legal owner and the individual Indian as a beneficial owner. See United States v. Rickert, 188 U.S. 432, 436 (1903). As legal owner, the government had great powers, while the Indian owner could do no more than occupy and cultivate the land. See, e.g., id. at 437; see also supra note 167. The Five Civilized Tribes, unlike most other tribes, had a fee simple interest in their land. See supra note 76 (Cherokee land). When most land was allotted, the allottees were held to have property rights protected by the fifth amendment due process clause, at least when they received their patent in exchange for giving up their claims to tribal property. See 
trust property ${ }^{\mathbf{1 6 \theta}}$ and to dispose of trust property was conditioned on approval by the Secretary of the Interior. ${ }^{170}$ Furthermore, individual Indian beneficiaries of congressional allotment schemes could not rely on the congressional largess bestowed on them. Statutes granting individuals property rights in the most explicit language were overturned by later statutes enlarging the class of beneficiaries and even, when congressional policy favoring tribal self-government resurfaced in the 1930 's, giving the land back to the tribe. ${ }^{171}$

First amendment rights, too, were curtailed drastically. Indian religions were banned upon threat of criminal prosecution in the Courts of Indian Offenses set up by the Bureau of Indian Affairs. ${ }^{172}$ Children were forced to attend schools to receive rations promised in return for land cessions. ${ }^{173}$ Moreover, the children were denied the right to speak their own language at the boarding schools. They were educated only in English and then only about American values. ${ }^{174}$ This coerced edu-

Choate v. Trapp, 244 U.S. 665, 667, 672-74 (1912) (tax exemption on Choctaw and Chickasaw fee simple allotted land is a property right). Nevertheless, this land was also subject to restrictions on alienation by the Act of Apr. 26, 1906, ch. 1876, $\S 22,34$ Stat. 137,145 , forbidding alienation of all allotted lands of members of the Five Civilized Tribes without the approval of the Secretary of the Interior. See Brader v. James, 246 U.S. 88 (1918) (upholding restriction as applied to alienation of Choctaw fee simple allotment after expiration of restriction in original fee patent); Tiger v. Western Investment Co., 221 U.S. 286, 316 (1911) (upholding the same law's extension of restriction on alienation during term of original restriction).

${ }^{169}$ See, e.g., LaMotte v. United States, 254 U.S. 570 (1921) (leasing allotted land); Taylor v. Tayrien, 51 F.2d 884 (10th Cir. 1931) (Congress made individual rights of Osage Indians to share in oil and gas revenues nontransferable); see also F. CoHEN, supra note 112, at 164.

170 F. CoHen, supra note 112, at 203-04. The Court has reviewed the Secretary of Interior's approval power over wills under the Administrative Procedure Act. See, e.g., Tooahnippah v. Hickel, 397 U.S. 598, 609-10 (1970) (statute vesting Secretary of Interior with power to disapprove wills of allotted land does not give Secretary power to "revoke or rewrite a will that reflects a rational testamentary scheme").

${ }_{171}$ See Act of July 24, 1968, Pub. L. No. 90-424, § 3, 82 Stat. 424, construed in Northern Cheyenne Tribe v. Hollowbreast, 425 U.S. 649 (1976) as altering the Northern Cheyenne Allotment Act, ch. 459, § 3, 44 Stat. 690, 691 (1926) by cancelling the distribution of mineral rights scheduled by the original act; Act of Apr. 26, 1906, ch. $1876, \S 2,34$ Stat. 137, amended by Act of June 21, 1906, ch. 3504, 34 Stat. 325, 34142 , construed in Gritts v. Fisher, 224 U.S. 640 (1912) as altering act of July 1, 1902 , ch. $1375, \S 31,32$ Stat. 716,721 , by increasing the number of Indians who could qualify for land to be granted under the original act.

172 See R. Berkhofer, JR., supra note 19, at 141; see also L. Kelly, The As-

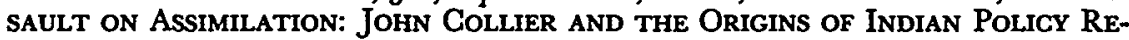
FORM 300-48 (1983) (history of attempts to suppress Indian religious practices, including dances).

173 Act of Feb. 28, 1877, ch. 72, 19 Stat. 254, 256, described in United States v. Sioux Nation of Indians, 448 U.S. 371, 383 n.14 (1980).

${ }^{174}$ See Atkins, The English Language in Indian Schools, in AMERIGANIzING THE AMERICAN INDIANS, supra note 45, at 197. For a rationalization of the methods of the Carlisle Indian School, where students were not permitted to speak their native lan- 
cation in Indian boarding schools continued even after the Supreme Court recognized the fundamental right of non-Indian families to oversee the education of their children by sending them to private schools or to schools where foreign languages were taught. ${ }^{175}$

Finally, individual Indians were subjected to liquor laws, whether or not they had severed tribal relations and whether or not they were on a reservation. ${ }^{176}$

In modern times, the Supreme Court has apparently repudiated both the ethnocentric overtones of the doctrine of plenary power and the doctrine itself, at least as far as the doctrine suggests it has an extra-constitutional source or is a power unlimited by other constitutional provisions. Nevertheless, the concept of plenary power continues to influence contemporary Indian law by conditioning the courts to defer to congressional power over Indian affairs. These developments are considered next.

\section{The Modern View of Congressional Power over Indians: The} Development of a More Restrictive View of the Guardian-Ward Relationship (1930's to Present)

As demonstrated above, barriers to access to the judicial system for Indian tribes and judicial deference to Congress, coupled with indifference to tribal and individual rights on the rare occasions Indians were allowed into court, marked the plenary power era, which lasted at least until the 1930's. In the 1930's and 1940's Congress repudiated the allotment and assimilation policy, which had come under much criticism, and adopted a policy of protecting tribal cultures and encouraging tribal self-government. ${ }^{177}$ This shift in policy undoubtedly affected the

guage, see Pratt, The Advantages of Mingling Indians with Whites, in id. at 260.

178 Pierce v. Society of Sisters, 268 U.S. 510 (1925) (Oregon law requiring children to attend public schools violated due process clause); Meyer v. Nebraska, 262 U.S. 390 (1923) (Nebraska law forbidding the teaching of German language violated due process clause).

${ }^{176}$ See, e.g., Hallowell v. United States, 221 U.S. 317 (1911) (upholding prosecution for violation of law against selling liquor to an Indian or Indian allottee). These liquor laws were explicitly racial. In Hallowell, for instance, despite the fact defendant had been active in county and state governments as judge, county attorney, county assessor, and director of a public school district, he was still subject to the law because of his status as an Indian. See id. at 320, 324. As the Eighth Circuit stated in a 1912 case: "The word 'Indian' (in the statute) describes a person of Indian blood. The word 'citizen' describes a political status." Mosier v. United States, 198 F. 54, 57 (8th Cir. 1912) (citizenship did not remove an Indian from coverage of liquor laws applicable to Indians).

177 See 1982 HaNDBOoK, supra note 3, at 144-52. For a history of John Collier's role in this era, see L. KelLY, supra note 172. 
Court, as demonstrated by an increased receptivity to Indian claims. ${ }^{178}$

First, both Congress and the judiciary opened the doors to the courthouses for Indians long denied ready access to the courts. For instance, the Court finally clarified the murky question of whether tribal Indians had standing to sue in federal court absent a congressional grant. During the allotment era, the Court had upheld the power of the executive to bring suit on behalf of Indian wards. In a broadly worded opinion, the Court had intimated that Indians not only could have no say in the litigation, but might also have no right to sue on their own behalf once the United States had undertaken their representation. ${ }^{\mathbf{1 7 9}}$ In 1943, the Court entertained a suit brought under a statute expressly permitting an aggrieved tribe to seek appellate review of a determination of the value of land taken by railroads. The Court held that the statute gave the tribe the right to sue, but added that Indian tribes also have "a general legal right" to bring lawsuits. ${ }^{180}$ Finally, in 1968, the Court made plain that an individual Indian's status as a ward of the United States did not preclude him from bringing suit on his own behalf. ${ }^{181}$

More important, Congress, by enacting the Indian Claims Commission Act of $1946,{ }^{182}$ finally removed the barrier of sovereign immunity to money claims against the government that had hindered tribes in the eighty-three years since the Court of Claims was created. Within five years, tribes filed more than five times as many claims against the government as they had during the entire sixty-five previous years. ${ }^{183}$ Finally, the 1976 passage of an amendment to the Administrative Procedure Act, waiving sovereign immunity for claims based on that statute, enabled Indians and Indian tribes to seek review of wrongful agency actions. ${ }^{184}$

As more Indian claims reached the judiciary, the Court began to narrow the Plenary Power Doctrine and repudiated the notion that Congress's plenary power could prevent the courts from reaching the

178 See infra notes 185-204 and accompanying text.

179 Heckman v. United States, 224 U.S. 413, 444-46 (1912); cf. Gherokee Nation v. Southern Kan. Ry., 135 U.S. 641, 652 (1890) (law permitted suit by tribe).

${ }^{180}$ Creek Nation v. United States, 318 U.S. 629, 640 (1943).

181 Poafpybitty v. Skelly Oil Co., 390 U.S. 365, 370-71 (1968) (construing Heckman v. United States, 224 U.S. 413 (1912), as implying that standing to sue existed).

${ }_{182}$ Indian Claims Commission Act of 1946, ch. 959, 60 Stat. 1049 (codified at 25 U.S.C. $\S \S 70$ to $70 v-3$ (1976 \& Supp. V 1981); 28 U.S.C. § 1505 (1976)).

183 Wilkinson, supra note 118 , at 512.

184 Act of Oct. 21, 1976, Pub. L. No. 94-574, 90 Stat. 2721 (codified at 5 U.S.C. $\S 702$ (1982)). For a discussion of pitfalls in suing the federal government, see Newton, Enforcing the Federal-Indian Trust Relationship After Mitchell, 31 GATH. U.L. REV. 635 (1982). 
merits of specific constitutional claims by Indian tribes. It did so in United States v. Creek Nation, ${ }^{185}$ a case presenting a textbook example of a fifth amendment taking. There, the government confiscated tribal fee simple absolute land by means of a survey wrongly denominating tribal land as a portion of land ceded in a treaty. When the government argued that the Plenary Power Doctrine immunized it from liability, the Court held that congressional power was not unlimited:

[Plenary authority over Indians] did not enable the United States to give the tribal lands to others, or to appropriate them to its own purposes, without rendering, or assuming an obligation to render, just compensation for them; for that "would not be an exercise of guardianship, but an act of confiscation."186

The Creek Nation case, however is not as significant a turning point as it might at first appear. In Creek Nation, Congress had permitted the tribe to press a fifth amendment taking claim by enacting special jurisdictional laws. ${ }^{187}$ Thus, the Court's receptivity to the claim may have been enhanced by its knowledge that both houses of Congress were cognizant that the tribe had been wronged.

Concurrently, the Court began to rely on specific provisions of the Constitution in place of inherent authority as the source of congressional power over Indians. The process was a gradual one. For instance, in 1958, the Court had referred to the Indian commerce clause as a major source of power over Indians in a case involving the licensing of traders on an Indian reservation. ${ }^{188}$ Even in a case with such a close commercial nexus, however, the Court still relied on Congress's guardianship power as the second major source of power, derived from "the necessity of giving uniform protection to a dependent people."189 By 1965, the Court relied solely on the Indian commerce clause in holding that a federal law regulating trading activities on Indian reservations preempted state taxation of those activities. ${ }^{190}$ Since the 1960's, the Court has looked increasingly to enumerated powers, especially the power to effectuate treaties, ${ }^{191}$ the Indian commerce clause, ${ }^{182}$ or

185295 U.S. 103 (1935).

${ }_{186} \mathrm{Id}$. at 110 (quoting Lane v. Pueblo of Santa Rosa, 249 U.S. 110, 113 (1919)).

187 Act of May 24, 1924, ch. 181, 43 Stat. 139, amended by Joint Resolution of May 19, 1926, ch. 341, 44 Stat. 568; Joint Resolution of Feb. 19, 1929, ch. 268, 45 Stat. 1229 (extending deadline for suits).

188 Williams v. Lee, 358 U.S. 217 (1959).

189 Id. at 219 n.4. (1965).

190 Warren Trading Post Co. v. Arizona Tax Comm'n, 380 U.S. 685, 691 n.18

191 See, e.g., Poafpybitty v. Skelly Oil Co., 390 U.S. 365, 368-69 (1968). 
both. ${ }^{193}$ Moreover, the Court repudiated the notion that Congress's plenary power was extraconstitutional, ruling rather that it was "drawn both explicitly and implicitly from the Constitution itself."

Recently, two of the strands from the post-New Deal case law just discussed have come together: the search for specific textual support in the Constitution for federal power over Indian affairs, and the Court's greater willingness to reach the merits of tribal constitutional claims. In 1977, in Delaware Tribal Business Committee v. Weeks, ${ }^{195}$ the Court adjudicated an equal protection challenge to the distribution of judgment funds by the Secretary of the Interior. The Court noted that power over tribal property, while plenary, is "rooted in the Constitution,"196 and may be challenged when it infringes constitutional rights. Moreover, the Court served notice that the political question doctrine, which had been invoked often in the past, had no place in cases raising individual rights guarantees:

The statement in Lone Wolf . . . that the power of Congress "has always been deemed a political one, not subject to be controlled by the judicial department of the government," however pertinent to the question then before the Court of congressional power to abrogate treaties ... has not deterred this Court, particularly in this day, from scrutinizing Indian legislation to determine whether it violates the equal protection component of the Fifth Amendment. ${ }^{197}$

By 1980, the Court had dismissed the political question doctrine: "[it] has long since been discredited in takings cases, and was expressly laid to rest in Delaware Tribal Business Comm. v. Weeks . . . ."198

The Court's ruling that federal power over Indian affairs was explicitly and implicitly rooted in the Constitution, and that the Plenary Power Doctrine would no longer bar the Court from reaching the merits of constitutional claims raised by Indian tribes, clearly was a major breakthrough. Nevertheless, the contours of this expanded role had to be more fully defined.

During this process of narrowing the Plenary Power Doctrine, the

182 See, e.g., United States v. John, 437 U.S. 634, 652-53 (1978).

(1973).

198 See, e.g., McClanahan v. Arizona State Tax Comm'n, 411 U.S. 164, 172 n.7

184 Morton v. Mancari, 417 U.S. 535, 551-52 (1974).

195430 U.S. 73 (1977).

$198 \mathrm{Id}$. at 83.

107 Id. at 84 (emphasis added) (quoting Lone Wolf v. Hitchcock, 187 U.S. 553, 565 (1903)).

${ }^{188}$ United States v. Sioux Nation, 448 U.S. 371, 413 (1980). 
Court also began to redefine its source-the guardian-ward relationship. Although the guardian-ward'relationship of Kagama was the basis for the power to impose federal criminal laws on tribal Indians, Kagama itself and other allotment era cases also referred to duties toward Indians imposed on the government by the guardian-ward relationship. ${ }^{199}$ These decisions treated the duties as self-imposed moral obligations, not legally enforceable. ${ }^{200}$ Nevertheless, in cases in which Congress had waived sovereign immunity, the judiciary began to impose duties on the government, akin to those imposed on ordinary fiduciaries, to manage Indian money and land responsibly. ${ }^{201}$ Indian breach of trust cases proliferated, and many were successful. Courts rendered specific relief or assessed money damages for breaches of a trustee's duties of care and loyalty in a number of cases involving mismanagement of money or natural resources. ${ }^{202}$ The result is that, in modernday Indian law, the trust relationship, although not constitutionally

199 Kagaina, 118 U.S. at 384.

200 See, e.g., Lone Wolf, 187 U.S. at 566 ("a moral obligation rested upon Congress to act in good faith in performing the stipulations entered into on its behalf"); Beecher v. Wetherby, 95 U.S. 517, 525 (1877) (extinguishment of title: "It is to be presumed that in this matter the United States would be governed by such considerations of justice as would control a Christian people in their treatment of an ignorant and dependent race.").

These obligations were held legally enforceable in situations arising from a breach of treaty or agreement. While the Court used contract language in some of these cases, e.g., Choate v. Trapp, 224 U.S. 665 (1912), it used trust terminology in holding the government had breached agreements in other cases, e.g., United States v. Mille Lac Chippewas, 229 U.S. 498, 509 (1913) (breach of agreement was a breach of trust, wrongfully disposing of tribal property).

The Court also employed the trust relationship to interpret treaties and statutes favorably toward Indians. See, e.g., Choctaw Nation v. United States, 119 U.S. 1, 28 (1886) (treaties) (trust relationship "recognizes . . . such an interpretation of their acts and promises as justice and reason demand in all cases where power is exerted by the strong over those to whom they owe care and protection"); see also Choate v. Trapp, 224 U.S. 665, 675 (1912) (liberal construction of statutes when the government is dealing with the Indians).

201 See, e.g., Seminole Nation v. United States, 316 U.S. 286, 297 (1942) (payment of money required to be paid per capita by treaty to tribal officers known to be corrupt violated "moral obligations of the highest responsibility and trust"); $\mathrm{Me}$ nominee Tribe of Indians v. United States, $101 \mathrm{Ct}$. Cl. 10 (1944) (mismanagement of tribal trust funds).

${ }^{202}$ See, e.g., Coast Indian Community v. United States, 550 F.2d 639 (Ct. Cl. 1977) (money damages for gross negligence by Secretary of Interior in managing tribal property); Jicarilla Apache Tribe v. Supron Energy Corp., 479 F. Supp. 536 (D.N.M. 1979) (declaration that Secretary of Interior breached trust in supervising oil and gas leases); Manchester Band of Pomo Indians, Inc. v. United States, 363 F. Supp. 1238 (N.D. Cal. 1973) (money damages and specific relief for Secretary's mismanagement of tribal trust funds); Pyramid Lake Paiute Tribe v. Morton, 354 F. Supp. 252 (D.D.C. 1973) (declaration that Secretary breached fiduciary duty in mismanagement of tribal water). 
based and thus not enforceable against Congress, ${ }^{203}$ is a source of enforceable rights against the executive branch and has become a major weapon in the arsenal of Indian rights. ${ }^{204}$

Perhaps the success of breach of trust claims has obscured the fact that the Plenary Power Doctrine has not been expunged completely from Indian law. Tribes wishing to impose fiduciary duties on the government did not challenge the government's power to manage and control Indian resources, but argued that the power carried duties along with it. Moreover, with the taming of the doctrine in recent years, most commentators have come to regard "plenary power" as referring only to the notion that the existing, fairly sketchy references to sources of power over Indians in the Constitution are to be read broadly, much as are the references to foreign affairs, and thus as giving the federal government primary power over Indian affairs. According to the Handbook of Federal Indian Law:

The teaching of modern cases is that acts of Congress affecting Indians are subject to judicial review, and that although congressional power is broad, ordinary constitutional protections may be invoked by Indians in the relationship with the federal government. Thus, while the courts refer on occasion to the "plenary power" of Congress over Indians, the term is not synonymous with "absolute" or "total." Rather, the phrase appears to be used as a summary of the congressional powers over Indians. ${ }^{205}$

Nevertheless, vestiges of the judicial attitude of nonintervention developed and nurtured in the plenary power era remain, especially in the areas of tribal sovereignty and property rights where the Court continues to rely on an inherent Indian affairs power of almost unlimited scope. For instance, the Court characterizes tribal sovereignty as existing "only at the sufferance of Congress,"206 which has "plenary authority to limit, modify or eliminate the powers of local self-government."207 As to property, the Court continues to recognize Congress's "paramount power over the property of the Indians."

${ }^{203}$ Menominee Tribe of Indians v. United States, 607 F.2d 1335 (Ct. Cl. 1979) (Congress immune from breach of trust claims), cert. denied, 445 U.S. 950 (1980).

204 See Chambers, Judicial Enforcement of the Federal Trust Responsibility to Indians, 27 STAN. L. Rev. 1213 (1975); see also 1982 HANDBOoK, supra note 3, at 22021 (trust doctrine "is one of the primary cornerstones of Indian law").

2051982 HaNDBOOK, supra note 3 , at 219.

206 United States v. Wheeler, 435 U.S. 313, 323 (1978).

207 Santa Clara Pueblo v. Martinez, 436 U.S. 49, 56 (1978).

208 United States v. Sioux Nation, 448 U.S. 371, 408 (1980) (quoting Lone Wolf v. Hitchcock, 187 U.S. 553, 565 (1903)). 
Court quite frankly explains that this power is derived "by virtue of [Congress's] superior position over the tribes"209 or even "the conquerors' will'210 — the kind of might-makes-right argument that resonates of nineteenth century Indian law jurisprudence. The following is a partial list of the congressional actions receiving the Court's sanction in modern times, often in decisions citing the major cases of the plenary power era. The court has upheld congressional power to reduce the boundaries of a reservation without tribal consent or compensation, ${ }^{211}$ thereby reducing, for all practical purposes, a tribe's power to govern. ${ }^{212}$ In addition the Court has upheld power to divest a tribe of all criminal, ${ }^{213}$ civil, or regulatory jurisdiction; ${ }^{214}$ to abrogate treaties; ${ }^{215}$ and to subject tribal laws and constitutions to federal approval. ${ }^{216}$ As to tribal property rights, congressional power remains as sweeping as it was during the plenary power era. Congress may require the Secretary of the Interior to approve land sales and leases by tribes, ${ }^{217}$ and contracts obligat-

209 Merrion v. Jicarilla Apache Tribe, 455 U.S. 130, 155 n.21 (1982).

210 Tee-Hit-Ton Indians v. United States, 348 U.S. 272, 290 (1955).

211 See, e.g., Rosebud Sioux Tribe v. Kneip, 430 U.S. 584, 594 (1977) (quoting Lone Wolf v. Hitchcock, 187 U.S. 553, 566, 568 (1903)); Antoine v. Washington, 420 U.S. 194, 204 (1975) (dicta); see also 1982 HANDBOoK, supra note 3, at 214-15.

212 See Rosebud Sioux Tribe v. Kneip, 430 U.S. 584, 630-33 (1977) (Marshall, $\mathrm{J}$., dissenting) (effect of reservation disestablishment on tribal self-government); Wilkinson \& Biggs, The Evolution of the Termination Policy, 5 AM. Indian L. Rev. 139, 153-54 (1977).

213 See Oliphant v. Suquamish Indian Tribe, 435 U.S. 191, 208-09 (1978) (citing United States v. Rogers, 45 U.S. (4 How.) 567, 571 (1846)) (tribal criminal jurisdiction over nonmembers implicitly divested because of tribes' dependent status); see also United States v. Wheeler, 435 U.S. 313, 323 (1978) (dicta).

214 See Washington v. Confederated Bands and Tribes of the Yakima Indian Nation, 439 U.S. 463, 501 (1979). See generally Wilkinson \& Biggs, supra note 212 (termination policy of the 1950's and its effect on tribal sovereignty).

218 See, e.g., United States v. Sioux Nation, 448 U.S. 371, 382, 383 n.14 (1980);

Rosebud Sioux Tribe v. Kneip, 430 U.S. 584, 594 (1977).

${ }_{216}$ The Indian Reorganization Act of 1934,25 U.S.C. $\$ \S 461-479$ (1976), permits tribes to adopt a constitution, subject to the approval of the Secretary of the Interior. Id. $\$ 476$. The reported decisions do not reveal that any tribe has ever challenged this IRA provision. The Supreme Court apparently finds the provision unobjectionable. See Merrion v. Jicarilla Apache Tribe, 455 U.S. 130, 141 (1982) (upholding tribal tax while stressing that the tax had secretarial approval). For a criticism of the IRA, see Barsh, Another Look at Reorganization: When Will Tribes Have a Choice?, InDIAN TRUTH, Oct. 1982, at 4.

${ }_{217}$ The restriction on alienation of tribal land, first enacted in 1790 , is still in effect today. 25 U.S.C. $\$ 177$ (1976); see Oneida Indian Nation of New York v. County of Oneida, 414 U.S. 661 (1974) (claim based on Nonintercourse Act states a federal claim). In addition, tribes have no power to lease their land without secretarial approval. 25 U.S.C. $\$ 415$ (1976). This provision and its implementing regulations have recently been read as preventing cancellation of a lease without approval because of concerns that increased power over leasing, while it might result in "enhancement of tribal power," would also increase the "risk of improvidence." Yavapai-Prescott Indian Tribe v. Watt, 707 F.2d 1072, 1075 (9th Cir. 1983). 
ing money held by the federal government but owed to the tribe. ${ }^{218}$ Congress may abrogate without liability future interests in Indian lands granted by earlier statutes, ${ }^{\mathbf{2 1 9}}$ and may enlarge or decrease the class of beneficiaries of tribal trust funds or lands. ${ }^{220}$ Congress may take one kind of tribal property, aboriginal Indian property, without paying compensation; ${ }^{221}$ it may, without consent, dispose of recognized-title tribal property under the guise of management and sell it at less than fair market value without liability, as long as the tribe receives some proceeds. ${ }^{222}$ According to some observers, it may even extinguish legal land claims of Indian tribes by retroactively extinguishing both title to the land and any claims based on that title. ${ }^{223}$

Obviously, these exercises of federal power raise individual and tribal rights concerns, which will be discussed in the next section. The conclusion is clear. Despite the Court's repudiation of the political question doctrine, it has been unable to shake a two-hundred-year history of deference to congressional decisions regarding federal power over property and sovereignty. This deference appears in the modern cases not as a refusal to address the merits of a claim but in the refusal to find any merit to the claim addressed. Extreme deference to Congress may have been proper in the early days of this nation's history,

21825 U.S.C. § 81 (1976).

219 Northern Cheyenne Tribe v. Hollowbreast, 425 U.S. 649, $655-56$ (1976) (subsurface rights promised allottees of surface lands in $\mathbf{5 0}$ years returned to tribal ownership).

${ }^{220}$ United States v. Jim, 409 U.S. 80, 82 (1972) (per curiam) (statutory trust fund for occupants of one portion of reservation enlarged to include occupants of the entire reservation). Although these decisions reflect the current federal policy of encouraging tribal self-government, they do so without careful analysis of the rights of the individuals. According to Justice Douglas, dissenting in Jim: "After all, Indians are beneficiaries of the Due Process Clause of the Fifth Amendment. They too are people, not sheep or cattle that can be given or denied whatever their overseer decrees." Id. at 87 (Douglas, J., dissenting) (citations omitted).

221 Tee-Hit-Ton Indians v. United States, 348 U.S. 272 (1955).

${ }^{222}$ Fort Berthold Reservation v. United States, 390 F.2d 686 (Ct. Cl. 1968), reasoning approved in United States v. Sioux Nation, 448 U.S. 371, 408-09 (1980).

${ }^{223}$ See Ancient Indian Claims Settlement Act of 1982, S. 2084, 97th Cong., 2d Sess. (1982). In supporting this bill, discussed infra notes 358-64 and accompanying text, the Solicitor of the Interior Department stated such retroactive extinguishment would be constitutional. Statement of William H. Coldiron, Solicitor, United States Department of the Interior, Before the Select Committee on Indian Affairs of the United States Senate, concerning S. 2084, "The Ancient Indian Land Claims Settlement Act of 1982," on June 23, 1982 (copy on file at the University of Pennsylvania Law Review); see also American land Trtle Association, Indian land Claims Under tHE Nonintercourse ACT: The Constrtutional Basis and NeEdS for A Legislative Solution 55-61, 85-90 (1978) (industry lobbying brief arguing that retroactive extinguishment or transfer of aboriginal or recognized title and claims based thereon would not constitute a taking of property within the meaning of the fifth amendment) [hereinafter cited as INDIAN LAND ClaIMS]. 
when Indians were regarded as holding allegiance to separate nations, and Congress dealt with them as if they were foreign nations. Indian affairs then were a branch of foreign affairs, an area in which the Court has traditionally deferred to the political branches both during war and peace, even though deference has meant giving less weight to individual rights concerns. ${ }^{224}$ Moreover, in the early years, the challenger of federal power was either a state or a non-Indian individual, threatening the supremacy of the national policy to open up the frontier, ${ }^{225}$ a policy to be advanced both by controlling the amount of contact between Indians and whites and by providing for the acquisition of Indian land. Finally, an important rationale for the Plenary Power Doctrine was the perceived racial and cultural inferiority of Indians. ${ }^{226}$ Today, however, the country has been settled, the national government's exclusive power to regulate Indian affairs has been solidified, Indian law has become domestic law, and Indian racial and cultural inferiority has been repudiated. Nevertheless, the Court's continued failure to attempt to define the extent of Congress's power over Indian affairs has encouraged further undue assertions of that power. If congressional policy were to shift again to one of forced assimilation, legislators might not be blamed for thinking the Court would place no limits on their actions.

\section{Limitations on Federal Power: Constitutional} Protection for Tribal Property and Sovereignty Rights

\section{A. Precedents and Problems}

Although state disenfranchisement of Indians continued into the twentieth century, ${ }^{227}$ individual Indians now enjoy the same constitu-

224 See, e.g., Haig v. Agee, 453 U.S. 280, 292 (1981) (revocation of passport of former CIA agent not a prior restraint); Fiallo v. Bell, 430 U.S. 787 (1977) (deferential scrutiny of federal legislation based on status of illegitimacy); Kleindienst v. Mandel, 408 U.S. 753 (1972) (denial of visa to Belgian Communist editor-in-chief of Socialist newspaper upheld despite infringement on first amendment rights of professors and students to receive information); Narenji v. Civiletti, 617 F.2d 745 (D.C. Cir. 1979) (national origin discrimination; deferential scrutiny of selective deportation of nonimmigrant alien Iranian students during hostage crisis), cert. denied, 446 U.S. 957 (1980), noted in 21 HARV. INT'L L.J. 467 (1980) (equal protection component of due process is weaker for aliens than for other minorities); see also Korematsu v. United States, 323 U.S. 214 (1944) (exclusion of persons of Japanese descent from the West Coast during World War II upheld against a due process attack).

225 F. Prucha, American Indian Policy in the Formative Years 3 (1962).

${ }^{220}$ See Carter, supra note 121, at 197; see also Shattuck \& Norgren, Political Use of the Legal Process by Black and American Indian Minorities, 22 How. L.J. 1 (1979).

${ }^{227}$ Cf. Montoya v. Bolack, 70 N.M. 196, 372 P.2d 387 (1962) (holding Navajo 
tional rights as other Americans. Tribal property and political sovereignty rights are a different matter, however. Attempts to assert constitutional protection for these rights have been largely unsuccessful for reasons discussed in the first part of this Article.

\section{Doctrine of Enumerated Powers}

As noted in part $\mathrm{I}$, the Court has defined congressional power over Indians in the broadest possible terms. The most analytically appealing and historically accurate basis for protecting tribal rights would be to limit federal power over Indian tribes, as advocated by Professor Robert Clinton. He argues that the framers intended to protect tribal sovereignty by vesting the power to deal with Indian tribes in the federal government alone and limiting that power to legislation dealing with commerce with Indian tribes. ${ }^{228}$ Although Glinton defines commerce broadly to include all intercourse between non-Indians, including states, and Indian tribes, ${ }^{22 \theta}$ he argues that such power should not be extended to permit congressional interference with purely intratribal matters. ${ }^{230}$

Clinton's historical research demonstrates that during the Colonial Period the Crown consistently recognized the sovereign status of Indian tribes. The Continental Congress maintained the same position, entering into treaties with tribes that guaranteed their legal and political autonomy. ${ }^{231}$

From his review of the history Clinton concludes that the framers intended both to "plac[e] the management of Indian affairs exclusively in the hands of the federal government, and [to] guarant[ee] the Indian tribes legal and political autonomy as sovereigns exempt from federal

Indians to be residents of the state and thus eligible to vote); Harrison v. Laveen, 67 Ariz. 337, 349, 196 P.2d 456, 463 (1948) (overruling 1928 case holding Indians to be "persons under guardianship" and thus not eligible to vote in state elections).

${ }^{228}$ Clinton, Isolated in Their Own Country: A Defense of Federal Protection of Indian Autonomy and Self-Government, 33 STAN. L. Rev. 979 (1981) [hereinafter cited as Clinton, Indian Autonomy]; Clinton, Book Review, 47 U. CHI. L. REv. 846 (1980) [hereinafter cited as Clinton, Book Review]. A recent commentator has taken a similar position, arguing that legislation designed to benefit Indian tribes ought to be permissible as an exercise of Congress's trusteeship power, but an exercise of power adverse to Indian interests should be confined to Congress's enumerated powers and tested accordingly. Comment, Federal Plenary Power in Indian Affairs After Weeks and Sioux Nation, 131 U. PA. L. Rev. 235 (1982).

${ }^{229}$ Clinton, Indian Autonomy, supra note 228, at 999.

230 Id. at $999-1000$.

231 Some of the former colonies, however refused to recognize tribal autonomy. For instance, Georgia's actions started an Indian war during the Constitutional Convention. Id. at 992-93; Clinton, Book Review, supra note 228, at 850-56. 
and state control over their internal affairs."232

Although the historical record amply supports the conclusion that the national governments of both England and the United States treated Indian tribes as possessing an inherent sovereignty, the historical evidence of the framers' intent to constitutionalize protection of Indian tribal sovereignty is less clear. Nevertheless, as Ely points out in a more general context, "the most important datum bearing on what was intended is the constitutional language itself." Constitution, in two clauses, recognizes the existence of Indian nations as separate sovereign peoples. First, the Indian commerce clause places Indian tribes on an equal footing with states and foreign nations by granting Congress the power "[ $t$ ]o regulate commerce with foreign nations, and among the several states and with the Indian tribes."234 Interpreting this provision in the Cherokee Cases, ${ }^{235}$ Chief Justice Marshall found that the Constitution recognized Indians as sovereign nations, albeit "domestic dependent nations."238 In Worcester v. Georgia ${ }^{237}$ he explained this phrase further: "The Indian nations had always been considered as distinct, independent political communities .... [T] power does not surrender its independence-its right to self-government, by associating with a stronger, and taking its protection."238

The second relevant constitutional provision is the apportionment clause of article $\mathrm{I},{ }^{239}$ now replaced by the fourteenth amendment apportionment clause. ${ }^{240}$ Both apportionment clauses explicitly exempt "Indians not taxed" from apportionment. Clinton argues that this ex-

232 Clinton, Book Review, supra note 228, at 851 .

233 J. Ely, Democracy and Distrust 16 (1980).

234 U.S. ConST. art. I, § 8, cl. 3.

23s Worcester v. Georgia, 31 U.S. (6 Pet.) 515, 559 (1832); Gherokee Nation v. Georgia, 30 U.S. (5 Pet.) 1, 18-20 (1831).

${ }_{238}$ Cherokee Nation v. Georgia, 30 U.S. (5 Pet.) 1, 17 (1831). In explaining the conclusion that Indian tribes could not sue as foreign nations, Chief Justice Marshall noted that the framers did not regard Indian tribes as foreign nations "not, we presume because a tribe may not be a nation, but because it is not foreign to the United States." Id. at 19.

23731 U.S. (6 Pet.) 515 (1832).

238 Id. at 559-61. Earlier in the opinion, in discussing the first treaty with the Cherokee Nation made after the Constitution had been adopted, the Chief Justice reaffirmed that the treaty did not surrender tribal self-governing rights: "This relation was that of a nation claiming and receiving the protection of one more powerful; not that of individuals abandoning their national character, and submitting, as subjects, to the laws of a master." Id. at 555 .

2so U.S. ConST. art. I, $\S 2$, cl. 3.

${ }^{240}$ Id. amend. XIV, $\S 2$ ("Representatives shall be apportioned among the several States according to their respective numbers, counting the whole number of persons in each State, excluding Indians not taxed."). 
clusion of Indians "from the enumeration for apportionment purposes reflects their autonomous political status."241 Thus, in 1787 and again in 1868, policymakers recognized that Indian nations were sovereigns exempt from ordinary laws, including taxing laws. ${ }^{242}$ Indeed, this provision provided the key to the Court's holding in Elk v. Wilkins ${ }^{243}$ in 1884, that Indians were not citizens. Although Supreme Court decisions later permitted federal taxation of Indians, ${ }^{244}$ the exclusion remains as a constitutional testimony of the separate status of Indian tribes. This conclusion, that Indian tribes were viewed historically as separate sovereigns, suggests the constitutional grant of power over Indians was intended to be limited. Thus, it could be argued that the government may not regulate wholly internal tribal affairs relating to tribal sovereignty.

As noted above, Clinton's argument is appealing. Nevertheless, the attempt to remove certain activities from the reach of federal power by carving out spheres of activity that cannot be reached by such power has proven nearly fruitless in this century. ${ }^{245}$ At best, as Clinton himself acknowledges, his argument supports only "a formal limit"246 on congressional power, akin to the tenuous limit the Court now imposes on congressional actions regulating matters affecting interstate commerce. $^{247}$

Since it is unlikely that the Court will limit the scope of federal power over Indian tribes, some advocates have attempted to invoke specific provisions of the Constitution, such as the fifth amendment, to protect tribal rights. Unfortunately, these efforts have been altogether rare and largely unsuccessful. The reasons are several. First, as Clin-

241 Clinton, Book Review, supra note 228 , at 857 .

262 See 1982 HanDBook, supra note 3, at 388-89.

24s 112 U.S. 94, 99, 102 (1884). The Court denominated Indian tribes as "alien nations, distinct political communities." Id. at 99.

244 See 1982 HandBook, supra note 3, at 389.

245 Compare National League of Cities v. Usery, 426 U.S. 833 (1976) (control of minimum wage and maximum hour levels of state employees beyond the reach of federal power) with EEOC v. Wyoming, $103 \mathrm{~S}$. Ct. 1054 (1983) (narrowing the reach of League of Cities to its facts). For a rare case successfully employing this limitation of power analysis, see Perry v. United States, 294 U.S. 330, 354 (1935) (cancellation of gold clauses in government bonds by Congress beyond its constitutional power). See generally Rostow, The Japanese American Cases-A Disaster, 54 YaLE L.J. 489, 51316 (1945). The defendants in Kagama had relied on the doctrine of enumerated powers, especially the Indian Commerce Clause, Brief for Defendants at 10, 19, United States v. Kagama, 118 U.S. 375 (1886), but to no avail.

${ }^{248}$ Clinton, Indian Autonomy, supra note 228, at 997.

267 See, e.g., Hodel v. Virginia Surface Mining and Recl. Ass'n, 452 U.S. 264 (1981) (local property use); Heart of Atlanta Motel v. United States, 379 U.S. 241 (1961) (public accommodations). 
ton's analysis suggests, and as the Court itself has acknowledged, ${ }^{248}$ Indian tribal rights do not fit neatly into the framework of existing constitutional interpretation or analysis. The peculiar nature of Indian sovereignty and the special status of Indian tribal ownership of land have contributed greatly to the problem.

Second, many tribal advocates have uncritically accepted doctrines developed in Indian law cases that might bear reexamination in light of the modern Court's expansion of constitutional liberties. Those advocates should turn their efforts towards convincing the Court to infuse specific constitutional guarantees, such as the due process clause, with new meaning relevant to Indian tribes. Such provisions may become a means of extending constitutional protection to tribal rights.

The task of constructing a constitutional framework that will protect tribal rights finds its most formidable barrier in the legacy of the plenary power era-the long tradition of judicial analysis justifying extraordinary federal power over Indian tribal property and sovereignty and thus creating powerful precedents impeding the application of meaningful judicial scrutiny of federal actions affecting tribal claims.

Still, while the task is difficult, it is essential. As canvassed in part I, the entire history of Indian law has been marked by judicial deference to congressional will regarding Indian policy. That abdication by the courts has resulted in the imposition of policies undermining Indian identity. Tribal membership is in fact at the core of Indian personal identity, reflecting much more than a shifting value choice or voluntary association. Thus, part II of the Article begins the difficult, but vital task of constructing a constitutional framework that will protect tribal rights. The suggested framework is founded on analogies to some of the following legal concepts: the expanded notion of property set forth in recent procedural due process cases; the increased protection given to contract rights; stricter scrutiny of retroactive legislation; heightened scrutiny under the due process clause of legislation infringing on fundamental rights; and heightened scrutiny under the equal protection clause of legislation discriminating on the basis of race or against discrete and insular minorities. The Article discusses the application of these concepts to Indian tribal property and sovereignty, the areas in which congressional power is regarded as having an almost unlimited reach.

Since extreme judicial deference to Congress-the legacy of the plenary power era-looms as the main obstacle to an assertion of tribal rights, any doctrinal argument will offer small comfort to Indian advo-

${ }^{248}$ Morton v. Mancari, 417 U.S. 535, 552-53 (1974). 
cates unless the Court can be convinced to subject legislation affecting Indian tribal interests to some level of heightened scrutiny. A discussion of the general justifications for that heightened scrutiny will follow. Once that overarching argument has been presented, the Article will consider three distinct constitutional provisions and their application to Indian legislation: the fifth amendment takings clause, the fifth amendment due process clause, and the equal protection component of the fifth amendment.

\section{B. Justifications for Heightened Scrutiny}

Since Calder v. Bull in $1798^{249}$ it has been recognized that property rights in general are explicitly protected by the Constitution. ${ }^{250}$ Similarly, the Constitution textually ${ }^{251}$ and structurally ${ }^{262}$ protects state sovereignty. Indian tribes, however, had no part in creating the Constitution. Thus, it is hardly surprising that their property and sovereignty rights are not explicitly protected by the Constitution. ${ }^{253}$

The arguments that follow attempt to find protection for tribal sovereignty and property in modern constitutional doctrine. ${ }^{254}$ These

2483 U.S. (3 Dall.) 386, 388 (1798) ("[A] law that takes property from A, and gives it to $B$ " would be unconstitutional).

${ }^{250}$ U.S. CoNST. art. I, $\S 10$ (bars state laws "impairing the obligation of contracts"); id. amend. V (due process and just compensation clauses); id. amend. XIV (due process); see also Webb's Fabulous Pharmacies, Inc. v. Beckwith, 449 U.S. 155, 164 (1980) (state retention of interest on money deposited into court in interpleader actions constituted a compensable taking) ("[A] State . . . may not transform private property into public property without compensation .... This is the very kind of thing that the Taking Clause of the Fifth Amendment was meant to prevent."). See generally L. TRIBE, supra note 18, § 9-1, at 456-57 (constitutional protection for settled expectations).

${ }_{251}$ U.S. Const. art I, § 9, cls. 5-6; art. I § 8, cl. 16; art. IV, § 3, art. V.

252 See National League of Cities v. Usery, 426 U.S. 833, 852 (1976) (a federal law that "directly displace[s] the States' freedom to structure integral operations in areas of traditional governmental functions" is outside of Congress's commerce clause authority).

${ }^{285}$ Although policymakers at one time considered making Indian Territory a state of the union governed by Indian tribes, pressure from those who desired Indian land forced the Congress to abandon the plan. See R. BERkHOFER, JR., supra note 19, at 164-65.

${ }^{254}$ Such arguments may be viewed as calling for noninterpretive judicial review. The word "may" is stressed because whether an analysis is interpretive or noninterpretive depends on the definitions of the two terms employed. For instance, John Hart Ely defines interpretivism as "indicating that judges deciding constitutional issues should confine themselves to enforcing norms that are stated or clearly implicit in the written Constitution." J. Ely, supra note 233, at 1. This definition leaves plenty of room for analytical manipulation, as Ely admits. Id. at 12 . Those who want to avoid the label of noninterpretivism-"enforc[ing] norms that cannot be discovered within the four corners of the document," id. at 1 , will justify their interpretation by arguing that the value they advocate is "clearly implicit." 
arguments are founded on the justifications that courts have advanced for occasionally deviating from their general practice of according congressional legislative judgments a "presumption of constitutionality" and instead applying some heightened level of scrutiny to government actions. Such deviations are especially significant in situations in which "a specific prohibition of the Constitution, such as those of the first ten amendments"285 is not invoked in opposition to a law. Whatever label may be given to such heightened scrutiny, the reasons the Court has chosen to take an aggressive role in interpreting some constitutional provisions are important for the theme of this Article. If it can be demonstrated that tribal property and sovereignty rights implicate values similar to those which the Court has protected in other settings, then the heightened scrutiny advanced to protect those values should be adopted more readily by the Court in relation to tribal rights. Furthermore, such a demonstration would suggest that if current precedents in Indian law conflict with values the Court has chosen to protect in other settings, those precedents deserve serious reconsideration.

Arguments for departing from the normal deferential standard of judicial review are important because, absent heightened scrutiny, the Constitution requires only that legislative decisions be rational. In the area of due process and equal protection review, for example, the Court sustains legislation if it is rationally related to a legitimate governmental interest. ${ }^{256}$ The legislative means need only be tenuously related to the legislative purpose; neither the relationship of the legislation to that purpose nor the purpose itself need be stated in the legislation; and when unstated, the Court will uphold the legislation if it bears even a hypothetically rational relationship to some legitimate government interest. $^{252}$

Because the judiciary has defined congressional authority over Indians so broadly, application of this deferential standard of review to Indian legislation permits almost any conceivable legislative action. In short, if the permissible statutory purpose is to manage Indian affairs, any legislation affecting Indians, almost by definition, would be rationally related to that purpose.

${ }^{255}$ United States v. Carolene Prods. Co., 304 U.S. 144, 152 n.4 (1938) (dictum) (Stone, J.). Not all provisions of the first ten amendments are specific, of course. See J. ELY, supra note 233 , at $12,32-41$.

${ }^{258}$ See Washington v. Confederated Bands and Tribes of the Yakima Indian Nation, 439 U.S. 463, 501 (1979) (quoting Massachusetts Bd. of Retirement v. Murgia, 427 U.S. 307,314 (1976)).

${ }^{257}$ For some of the principal discussions of deferential review, see, McDonald v. Board of Election Comm'rs, 394 U.S. 802, 809 (1969); McGowan v. Maryland, 366 U.S. 420 (1961); Williamson v. Lee Optical Co., 348 U.S. 483 (1955). 
Arguably the most controversial rationale advanced in favor of heightened judicial review is the theory that the Court should enforce fundamental values not explicitly stated in the Constitution ${ }^{258}$ but derived from natural law, reason, tradition, or consensus ${ }^{258}$ - "the traditions and conscience of our people."260 In recent years, the Court has begun to scrutinize more carefully legislation "significantly interfer[ing]"261 with some personal rights embodied in the concept of liberty in the fifth and fourteenth amendments. When these fundamental rights are involved, the Court requires that legislation serve at least an important, ${ }^{262}$ and sometimes a compelling, ${ }^{263}$ articulated governmental interest by means that are "closely tailored to effectuate only those interests."264 Some "tenuous relation"265 between legislative means and government purpose will not suffice.

Concededly, this more searching scrutiny has occurred only in cases involving a 'substantial claim of infringement on the individual's freedom of choice with respect to certain basic matters of procreation, marriage, and family life." 266 Thus, any assertion of tribal property or sovereignty rights immediately suggests doctrinal problems. Tribal rights do no appear to implicate the same values as the autonomy and privacy interests protected by the Burger Court through heightened scrutiny of congressional action. In addition, such property and sovereignty rights rest nominally in the tribe as a collective entity, while autonomy and privacy are quintessentially personal and individual rights. A close examination of these rights asserted by tribes in the context of a true understanding of the concept of a tribe indicates, however,

${ }^{258}$ For scholarly defenses of the right to privacy see, e.g., Perry, Noninterpretive Review in Human Rights Cases: A Functional Justification, 56 N.Y.U. L. REv. 278 (1981); Richards, Sexual Autonomy and the Constitutional Right to Privacy: A Case Study in Human Rights and the Unwritten Constitution, 30 Hastings L.J. 957 (1979).

250 For a criticism of these sources of fundamental values, see J. ELY, supra note 233, at 48-69.

280 Griswold v. Connecticut, 381 U.S. 479, 487 (1965) (Goldberg, J., concurring) (quoting Snyder v. Massachusetts, 291 U.S. 97, 105 (1934) (Cardozo, J.)).

${ }^{261}$ Zablocki v. Redhail, 434 U.S. 374, 388 (1978) (state law outlawing remarriage by persons who could not prove that they had no outstanding support obligations violated the equal protection clause by denying the affected class the fundamental right to marry).

282 See Moore v. City of E. Cleveland, 431 U.S. 494, 499 (1977) (invalidating zoning ordinance limiting occupancy of single family dwellings to nuclear families as violating the due process clause).

${ }^{263}$ See Roe v. Wade, 410 U.S. 113, 155-56 (1973) (invalidating state laws restricting the right to have an abortion) (quoting Kramer v. Union Free School Dist., 395 U.S. 621, 627 (1969)).

264 Zablocki v. Redhail, 434 U.S. 374,388 (1978).

${ }^{28 s}$ Moore v. City of E. Cleveland, 431 U.S. 494, 500 (1977).

${ }^{288}$ Kelley v. Johnson, 425 U.S. 238, 244 (1976) (Rehnquist, J.). 
that tribal rights lie very close indeed to the individual fundamental rights now protected by the courts, and far from the rights derived from "shifting economic arrangements" protection.

At the time of discovery, the cultures of the many indigenous tribes varied widely. ${ }^{288}$ Even today Indians do not constitute a monolithic group. The ethnic boundaries defining group identity and functions are essentially tribal in nature. ${ }^{269}$ At the same time, tribal membership is at the core of Indian personal identity, reflecting much more than a shifting political value choice or voluntary association. The tribe is a projection of the autonomous individual Indian. ${ }^{270}$ To some extent this unique interrelationship between tribe and individual identity is already recognized in the law: tribal membership as defined by the tribe is often the key element in determining whether a person is an Indian for some legal purposes. ${ }^{271}$

While all tribes have undergone a certain degree of assimilation, ${ }^{272}$ the importance to individual Indian selfhood of the existence of a tribal community cannot be understated. Studies of Indians outside a tribal structure support this view. For instance, there is evidence that even urban Indians often form distinct Indian communities to preserve, as much as possible, the core of a native tribal style of life. ${ }^{273}$ Thus, some have concluded that the overwhelming majority of Indians in this country seek to remain "tribal members," whether or not their tribe is recognized by the federal government. ${ }^{274}$

Professor Laurence Tribe has argued that courts should identify and protect certain "personhood rights."275 According to Tribe, virtually every invasion of private personhood is also an interference with the way in which one associates with society; concomitantly, virtually every intrusion upon association works a displacement of fundamental human personality. ${ }^{276}$ Surely this concept of personhood rights would encompass the unique relationship of personal Indian selfhood and tribalism. Consequently, government actions undermining tribalism should be regarded as examples of the government dictating the kinds

${ }^{287}$ Kovacs v. Cooper, 336 U.S. 77, 95 (1949) (opinion of Frankfurter, J.).

${ }^{268}$ Weatherhead, What is an Indian Tribe?, 8 AM. Indian L. REv. 1, 5 (1980).

${ }^{269}$ D. McNickle, Native American Tribalism 116 (1973).

$270 \mathrm{Id}$.

${ }^{271}$ See 1982 HandBook, supra note 3, at 3.

${ }^{272}$ See Weatherhead, supra note 268 , at 20.

${ }^{273}$ See D. MCNickle, supra note 269 , at 7.

274 See Weatherhead, supra note 268 , at 21.

278 See L. TRIBE, supra note $18, \S \S 15-1$ to $15-21$, at $886-990$.

${ }^{276}$ Sep id. § 15-18, at 974. 
of lives people may lead. ${ }^{\mathbf{2 7}}$ Moreover, such actions would violate Indian selfhood in much the same way as a ban on contraceptives invades the autonomy marriage gives a couple. ${ }^{278}$ The point is not that these rights of Indians are more important than those asserted by other groups seeking heightened judicial protection, but that the essential underpinnings of the Indian personhood concept are as implicit in the Constitution's protection of privacy and autonomy as the rights thus far recognized as fundamental by the Supreme Court.

A second rationale for heightened scrutiny, eloquently defended by John Hart Ely, ${ }^{278}$ focuses on the Court's duty to intervene in those cases where the political process has not worked. In his famous justification for lenient review of commercial legislation, Justice Stone noted that a "more searching judicial inquiry" might be appropriate for "statutes directed at particular religious, or national, or racial minorities" because "prejudice against discrete and insular minorities may be a special condition, which tends seriously to curtail the operation of those political processes ordinarily to be relied upon to protect minorities."280 This "political process rationale" has become a major justification for the development under the equal protection clause of strict scrutiny of legislation that discriminates on the basis of racial and ethnic classifications. ${ }^{281}$

Surely tribal Indians are among the most vulnerable of all racial and cultural groups to the majoritarian process. They comprise less than one percent of the nation's population. ${ }^{282}$ Tribal Indians live apart from other Americans on reservations; most tribes are poor; they often speak tribal languages and maintain aspects of their ancient cultures that differ substantially from dominant American cultural values. ${ }^{283}$ In addition to being small insular groups possessing alien cultures, most tribes lack financial strength, except those fortunate enough to possess valuable natural resources. ${ }^{284}$ Moreover, contrary to conventional wis-

277 See id. § 15-4, at 897 .

278 Griswold v. Connecticut, 381 U.S. 479 (1965).

$279 \mathrm{~J}$. ELY, supra note 233, at 73-104.

280 United States v. Carolene Prods. Co., 304 U.S. 144, 153 n.4 (1938).

281 For an eloquent defense of judicial intervention to protect minorities, see Ely, Toward a Representation-Reinforcing Mode of Judicial Review, $37 \mathrm{MD}$. L. REv. 451 (1978).

${ }_{282}$ U.S. Bureau of the Census, Dep't of Commerce, Statistical ABSTRACT OF THE UnIted States 32 (1981) (Table 36, Resident Population, by Race and Spanish Origin by State: 1980) (Indians, including Eskimos and Aleuts, total $1,418,000$ out of a national population of $226,505,000)$.

${ }_{283}$ D. Getches, D. Rosenfelt \& C. Wilkinson, supra note 27, at 20. For a list of tribes under state control, terminated tribes and other tribes not federally recognized, see T. TAYLOR, supra note 166 , app. J, at 226-32.

284 See D. Getches, D. Rosenfelt \& C. Wilkinson, supra note 27 , at 4-5, 9 , 
dom, the more than 200 Indian tribes ${ }^{285}$ in the United States are diverse and have no real community of political interest. Accordingly, the appropriate entity for evaluating Indian political power is not the racial grouping "Indians" but rather the separate, often politically impotent, individual tribes. Indian tribes are, in short, the paradigmatic example of "discrete and insular minorities."

In addition, Indian tribes meet other conditions the courts traditionally have found to justify heightened judicial scrutiny under the equal protection clause. The Court has observed that a suspect class is one subject to a "history of purposeful unequal treatment."28z As discussed in part $I$ of this Article, Indians have been subject to such a history. Only in the last thirty years has de jure discrimination against Indians ceased-as recently as 1956 reservation Indians were still disabled from voting in some state elections. ${ }^{288}$ In applying heightened scrutiny, the Court has also looked to the existence of "unique disabilities on the basis of stereotyped characteristics not truly indicative of their abilities."289 As stated above, Court opinions justifying federal power over Indians at the height of the plenary power era were replete with references to the dissolute habits and general inferiority of the Indian race. ${ }^{280}$ This stereotyping has continued into recent history. As late as 1955, the Court stated, "Every American schoolboy knows the savage tribes of this continent were deprived of their ancestral ranges by force . . .."201 Such stereotyping is inaccurate. Many Indian tribes did not wage war on the United States. Indeed, some, like the Alaskan natives whose property rights to Alaska were denied in the same Supreme Court decision cited above, had welcomed settlers to their

14-15.

${ }^{28 B} I d$. at 5.

${ }^{288}$ United States v. Carolene Prods. Co., 304 U.S. 144, 153 n.4 (1938); see also Fetzer, Jurisdictional Decisions in Indian Law: The Importance of Extralegal Factors in Judicial Decision Making, 9 AM. IndiAN L. REv. 253, 254-55 (1981) (arguing that whenever Indians represent a minority of the population of a reservation, the court rules against claims of tribal sovereignty).

${ }^{287}$ Massachusetts Bd. of Retirement v. Murgia, 427 U.S. 307, 313 (1976) (quoting San Antonio Indep. School Dist. v. Rodriguez, 411 U.S. 1, 28 (1973)).

${ }^{288}$ See Allen v. Merrell, 6 Utah 2d 32, 305 P.2d 490 (1956), vacated and remanded, 353 U.S. 932 (1957) (upholding denial of suffrage by Utah to persons residing on Indian reservations) (the Supreme Court vacated and remanded because the Utah legislature repealed the statute while the case was on appeal); see also Crvin Rights Commission REPORT, supra note 27, at 36-37 (report of efforts to combat continuing discrimination against Indians in voting rights).

288 Massachusetts Bd. of Retirement v. Murgia, 427 U.S. 307, 313 (1976).

200 See supra note 121 and accompanying text; see also Civil. Righrs CommisSION REPORT, supra note 27, at 33-35 (continuing legacy of racism).

291 Tee-Hit-Ton Indians v. United States, 348 U.S. 272, 289-90 (1955). 
country. ${ }^{282}$

In conclusion, the same factors that the Court has relied on to justify heightened scrutiny in other settings would justify the Court's taking a more active role in evaluating challenges to congressional power over Indian tribes. In the hope that tribal advocates will begin to encourage an increased judicial activism, the next section turns to the specific constitutional provisions that have been or might be used to raise these challenges.

\section{Due Process and Tribal Property Rights}

\section{Aboriginal Land}

\section{a. Tee-Hit-Ton and the Fifth Amendment}

Cases involving the fifth amendment takings clause most clearly illustrate the failure of the Court to offer constitutional protection to Indian interests. The Court has frequently stated the value furthered by the takings clause: "The Fifth Amendment's guarantee . . . was designed to bar the government from forcing some people alone to bear public burdens which, in all fairness and justice, should be borne by the public at large."293 In its normal application, the fifth amendment's proscription against government confiscation of land without compensation protects every sort of property, from land held in fee simple to periodic tenancies and future interests. ${ }^{294}$ Despite this proscription, in 1955, the Court held, in Tee-Hit-Ton Indians v. United States, ${ }^{285}$ that absent a treaty or statute granting an Indian tribe the right to occupy its ancestral land permanently, Indian aboriginal land ${ }^{296}$ is not property for the purposes of the takings clause requirement of payment of just compensation. ${ }^{297}$ As a result of the rule of Tee-Hit-Ton, the native peoples of Alaska lost their claim to most of Alaska's 272 million

292 See generally Federal Field Committee for Development Planning in Alaska, Alaska Natives and the Land 429-54, 535 (1968) (history of peaceful relations between natives and settlers and native attempts to resolve disputes through the legal process).

283 Armstrong v. United States, 364 U.S. 40, 49 (1960).

294 See, e.g., Alamo Land \& Cattle Co. v. Arizona, 424 U.S. 295, 303 (1976) (the rights of periodic tenants); United States v. 376.21 Acres, 240 F. Supp. 163, 165 (W.D. Pa. 1965) (future interests); United States v. Certain Lands, 220 F. Supp. 696, 701 (D. Me. 1963) (equitable servitudes). See generally 2 J. Sackman, Nichols' The Law of EMINent Domain, $7 f$ 5.02[1], 5.04[1]-[3], 5.06 (rev. 3d ed. 1982).

205348 U.S. 272 (1955).

286 "Aboriginal title is a right of occupancy based on possession from time immemorial." Inupiat Community of Arctic Slope v. United States, 680 F.2d 122, 128 (Ct. Cl.) (citation omitted), cert. denied, 103 S. Ct. 299 (1982)..

287 Tee-Hit-Ton, 348 U.S. at 285. 
acres. ${ }^{298}$ The beneficiaries were the state of Alaska, its oil company lessees and citizens, and the American public. ${ }^{209}$

Although written in 1955, the Tee-Hit-Ton opinion is a paradigm of the plenary power era judicial style, ${ }^{300}$ both in its slighting reference to the natives' cultures ${ }^{301}$ and in its repeated invocations of the political question doctrine ${ }^{302}$ as tying the hands of the judiciary. Most important, in relying on the Doctrine of Discovery to justify the result, the Court expanded that doctrine from a doctrine protective of aboriginal land rights to one permitting arbitrary confiscation without payment of compensation. In Johnson v. McIntosh, ${ }^{303}$ Chief Justice Marshall had stated that by virtue of discovering the New World, the occupying powers gained a preemptive right to extinguish Indian title either by purchasing all the land tribes desired to sell or by conquest. ${ }^{304}$ In Worcester v. Georgia, ${ }^{305}$ the Ghief Justice limited extinguishment by conquest to conquest after just wars in which the Indians had been the aggressors. ${ }^{306}$ The Tee-Hit-Ton Court, nevertheless, held that the government had conquered all Indian tribes (including presumably the peace-loving Tlingets of Alaska, plaintiffs in the suit). ${ }^{\mathbf{3 0 z}}$ Accordingly, the federal government gained title to all Indian land merely by virtue of its superior ability to use force, whether or not it actually had used force in a given case. Having acquired ownership rights to all Indian land, the government could then grant land back to an Indian tribe,

${ }^{298}$ See Edwardsen v. Morton, 369 F. Supp. 1359, 1371-73, 1378 (D.D.C. 1973) (upholding Native Claims Settlement Act which extinguished the aboriginal title claims to Alaskan lands).

209 Alaska was entitled to select slightly more than 100 million acres of land upon becoming a state. Alaska Statehood Act, Pub. L. No. 85-508, $\$$ 6(a), (b), 72 Stat. 339, 340 (1958) (set forth preceeding 48 U.S.C. $\$ 21$ (1976)). As of 1958, the state had already leased Prudhoe Bay to oil companies for more than $\$ 900$ million. See Edwardsen v. Morton, 369 F. Supp. 1359, 1364 (D.D.C. 1973). These leases and other oil leases have produced so much income, $\$ 3.7$ billion in revenues during fiscal 1981 alone, for example, that the state has begun to develop schemes to distribute the money to its citizens. See Zobel v. Williams, 457 U.S. 55, 57 (1982) (statute distributing dividends based on residency violates equal protection clause).

${ }^{300}$ See supra text accompanying note 80.

${ }^{301}$ See Tee-Hit-Ton, 348 U.S. at 273, 287.

302 See id. at 280-81.

sos 21 U.S. (8 Wheat.) 543 (1823).

$304 \mathrm{Id}$. at 587.

sos 31 U.S. (6 Pet.) 515 (1832).

sos Id. at 545-47.

307 Tee-Hit-Ton, 348 U.S. at 279-80 (citing Johnson v. McIntosh, 21 U.S. (8 Wheat.), at 587). The Court's reliance on Johnson has been criticized. See, e.g., Hookey, The Gove Land Rights Case: A Judicial Dispensation for the Taking of Aboriginal Lands in Australia?, 5 FED. L. REv. 85, 101 (1972) (Tee-Hit-Ton rule was "a surprising finding . . . made in the course of following rather than, as might have been supposed, overruling Johnson v. McIntosh"). 
giving it a vested property right, called recognized title. ${ }^{308}$ If, however, Congress failed to grant a tribe title, it could later confiscate that land, extinguishing Indian title, without payment of just compensation. ${ }^{309}$

The Tee-Hit-Ton rule remains relevant today because many tribes live on executive order reservations that have never been recognized by Congress. ${ }^{310}$ Furthermore, some tribes with reservations established in treaties may not have recognized title, because the treaty did not contain sufficient language regarding permanency. ${ }^{311}$.

As a modern demonstration that tribal land claims based on aboriginal Indian title are not accorded even basic constitutional protection, Tee-Hit-Ton is a landmark decision. Yet, the case has a more fundamental significance. Tee-Hit-Ton reveals a judicial attitude so committed to congressional deference that the Court was willing to engage in the intellectual dishonesty of characterizing the acquisition of Alaska as a conquest to avoid protecting tribal rights. ${ }^{312}$ So viewed, Tee-Hit-Ton is astonishing only because it was so predictable.

\section{b. Due Process and Aboriginal land}

Fortunately, the government has not recently adopted the policy of terminating Indian reservations, and continues to repudiate the last such episode, occurring the the 1950's. ${ }^{313}$ Tee-Hit-Ton's declaration that aboriginal title is not property within the meaning of the fifth amendment takings clause Nevertheless, Tee-Hit-Ton's declaration continues to cast a towering shadow over Indian property law. Its holding casts doubt on the ability of tribal advocates to invoke the due process clause to protect aboriginal land. Tribal advocates have invoked only occasionally that clause to argue for either procedural protection against unwarranted government action or as a substantive limitation of

${ }^{308}$ See Tee-Hit-Ton, 348 U.S. at 278-79 (dictum).
s09 See id. at 281.
310 See Newton, supra note 70 , at 1257-59.
311 See id. at $1259-64$.
312 See generally id. at $1253-67$ (effects of Tee-Hit-Ton).
s13 Statement of President Reagan on Indian Policy, 19 WEEkLY CoMP. PRES. Doc. 98 (Jan. 24, 1983). During the termination era of the 1950's and 1960's, "approximately 109 [Indian] tribes and bands were terminated. A minimum of 1,362,155 acres and 11,466 individuals were affected." Wilkinson \& Biggs, The Evolution of the Termination Policy, 5 AM. Indian L. REv. 139, 151 (1977). Congress did not seek Indian tribal consent to the numerous termination statutes. Id. at 157, $179 \mathrm{nn} .194-99$. Upon termination a tribe lost its tribal land, although proceeds from the sale were given to the tribe. Id. at 152 . Although the termination acts did not explicitly abrogate tribal sovereignty, the lack of a land base over which to exercise authority effectively ended tribal sovereignty. As Wilkinson and Biggs reported, "with one exception, no terminated tribe has continued to enforce any laws after termination." Id. at 154. For a summary of other effects of termination, see id. at 152-53. 
federal power. ${ }^{314}$ Since Tee-Hit-Ton was decided in 1955, however, the definition of property has been expanded in cases raising procedural due process challenges. These cases surely merit closer attention by tribal advocates, for arguably these expansions of the concept of property in procedural due process claims should not be considered in isolation from the definition of property for takings; and for substantive due process. $^{315}$ This section will argue that the expanded notion of property for procedural due process purposes suggests that the Court must reassess its holding in Tee-Hit-Ton: aboriginal land is property for which compensation must be given after a taking by the government. Beyond that, the expanded notion of property may be extended to the notion of property for substantive due process purposes as well.

In brief, the Court has stated that a party claiming procedural due process protection need not claim "actual ownership of real estate, chattels, or money," claim of entitlement,"318 grounded in "rules or understandings that stem from [a source] independent [of the Constitution]."319 Tribes could, thus, rely on Goldberg $v$. Kelly, ${ }^{320}$ recognizing welfare as a statutorily created entitlement that could not be cut off without according the claimant procedural rights, to argue that the Nonintercourse Act created a statutory entitlement legitimizing tribal claims to the land vis à vis the states. Absent a repeal of the statute itself, which has not been

s14 See, e.g., Washington v. Confederated Bands and Tribes of the Yakima Indian Nation, 439 U.S. 463, 501 (1979) (Court rejected claims that Indian classifications were suspect and that tribal sovereignty was a fundamental right); Edwardsen v. Morton, 369 F. Supp. 1359, 1379 (D.D.C. 1973) (retroactive extinguishment of claims based on aboriginal title would violate the due process clause; therefore Native Claims Settlement Act interpreted to extinguish only claims claims directly challenging title to land).

Due process review normally is very limited, however, protecting persons only from arbitrary governmental action. See Williamson v. Lee Optical Co., 348 U.S. 483 (1955); see also Perrin v. United States, 232 U.S. 478, 486 (1914) (dictum) (Congress could not use the pretext that a few Indians were residents to legislate for an entire state). For instance, the Court has stated that Congress may not arbitrarily label a group of non-Indians as Indians for the purposes of bringing them within its power to regulate Indian affairs. United States v. Sandoval, 231 U.S. 28, 46 (1913) (dictum). Apart from this unlikely hypothetical situation, however, any legislation regarding tribal Indians, which does not violate some other specific constitutional guarantee, would be permissible under the minimal rationality standard of review employed by the Court.

s1s Cf. Webb's Fabulous Pharmacies, Inc. v. Beckwith, 449 U.S. 155, 161 (1980) (relying on Board of Regents v. Roth, 408 U.S. 564 (1972), a procedural due process case, for a definition of property for purposes of the takings clause).

316 Board of Regents v. Roth, 408 U.S. 564, 572 (1972).

317 Goldberg v. Kelly, 397 U.S. 254, 262 (1970) (statutory welfare benefits).

318 Perry v. Sindermann, 408 U.S. 593, 602-03 (1972) (de facto tenure system).

319 Board of Regents v. Roth, 408 U.S. 564, 577 (1972).

320397 U.S. 254 (1970). 
attempted, Congress must respect this property right and cannot extinguish title in favor of state claims.

Furthermore, by analogy to Perry $v$. Sindermann, ${ }^{321}$ tribes might argue that aboriginal title is property. In Perry, the Court held that a de facto tenure system created a legitimate expectation of continued employment in a teacher fired without a hearing. ${ }^{322}$ By parity of reasoning, Indian use and occupancy of aboriginal land continuing to the present day ${ }^{\mathbf{3 2 3}}$ creates a de facto ownership interest qualifying as property for due process purposes. To bolster this argument, tribes could invoke the guardianship relationship itself and the often-repeated judicial and executive promises ${ }^{\mathbf{3 2 4}}$ to protect Indian land from further confiscation. Uncontrovertably, a major hurdle to this argument is the Court's insistence that, at least in the procedural context, property does not have an independent constitutional basis, but must be grounded in an independent source of state or federal law. ${ }^{325}$ Tee-Hit-Ton could be read as establishing that the relevant body of federal law does not create any sort of property interest in aboriginal Indian land. Under the analogy to Goldberg and Perry, however, the holding in Tee-Hit-Ton is simply no longer correct. Tee-Hit-Ton was decided in an era before the concept of property was as fully developed as now. The decision therefore did not consider the body of law and tradition mentioned above that granted a legitimate claim of entitlement to or a de facto ownership interest in aboriginal land. These expanded notions of property developed in procedural due process cases undercut the Court's primary rationale for denying fifth amendment protection to Indian property-that it simply is not property.

321 408 U.S. 593 (1972).

322 Id. at 602-03; cf. Board of Regents v. Roth, 408 U.S. 564, 578 n.16 (1972) (no evidence of customary rehiring, as in Perry; therefore, nontenured teacher not entitled to procedural due process rights).

s2s A tribe that lost its aboriginal land in violation of the Nonintercourse Act 200 years ago would find it more difficult to rely on procedural due process, for such reliance usually requires the deprivation of benefits "presently enjoyed" by the property owner. Menechino v. Oswald, 430 F.2d 403, 408 (2d Cir. 1970), cert. denied, 400 U.S. 1023 (1971) (citing Goldberg v. Kelly, 397 U.S. 254, 262 (1970) (termination of welfare benefits)); see also Board of Regents v. Roth, 408 U.S. 564, 576 (1972) (dictum) ("The Fourteenth Amendment's procedural protection of property is a safeguard . . . of interests . . . already acquired . . . ."); Bell v. Burson, 402 U.S. 535, 539 (1971) (revocation of driver's license). Reliance on present enjoyment to determine availability of procedural due process rights has been criticized. See L. TRIBE, supra note 18, § 109, at 519-20. Tribes currently possessing aboriginal property might have greater success in claiming a statutory entitlement however. Since the Nonintercourse Act applies to all Indian land, such an argument could have far-reaching implications.

324 For a discussion of promises made regarding tribal land, see 1982 HANDBOOK, supra note 3 , at $473-99$.

${ }^{323}$ Board of Regents v. Roth, 408 U.S. 564, 577 (1972). 
Nevertheless, convincing a court that aboriginal title is property for procedural due process purposes is only an initial step. The second step is to argue that aboriginal title is property for substantive due process and takings clause purposes as well. While it is difficult to locate precisely the constitutional source of the tribal right to aboriginal property, legal scholars have commented on the near intuitive sense of fairness in the idea that courts should treat aboriginal land on which a tribe has lived for several generations as property, and government deprivation of this property as worthy of more than minimal scrutiny. In a memorandum to Judge Gunter, appointed by President Carter to mediate the now-settled claims of the Passamaquoddy and Penobscot Tribes against Maine, Professor Archibald Cox argued that congressional extinguishment of aboriginal title today "would violate the guarantees of fundamental fairness embodied in the Due Process Clause."326 Although Tee-Hit-Ton may have some significance in "technical claim[s] to "just compensation," "327 the memorandum argued, simply transferring aboriginal Indian lands to non-Indians without either compensation or any other means of improving the Indians' lot would be arbitrary and capricious. ${ }^{328}$

Professor Cox's memorandum essentially invoked substantive due process by arguing that aboriginal property should be protected from arbitrary governmental actions. The memorandum did not, however, suggest a particularly high standard of judicial review of federal action affecting aboriginal land.

To trigger this higher standard of review, advocates would have to argue the continued possession of aboriginal property is a fundamental tribal right. It can be argued that the Indian right to aboriginal land is fundamental because land is the basis of all things Indian. ${ }^{329}$ The relationship of a tribe to its land defines the tribe: its identity, its culture, its way of life, and its methods of adaptation..$^{330}$ Since tribal existence is central to personal Indian selfhood, ${ }^{331}$ the very existence of an Indian people is largely dependent on the recognition and protection of Indian property rights. ${ }^{332}$

s28 Memorandum from Archibald Cox to the Honorable William B. Gunter 20 (Apr. 29, 1977) (on file with the University of Pennsylvania Law Review) [hereinafter cited as Cox.Memorandum] (a portion of the memorandum is reprinted in D. GETCHES, D. Rosenfelt \& C. WILKINSON, supra note 27, at 249-52).

327 Cox Memorandum, supra note 326, at 24.

328 Id. at 23-24.

329 E. Gahn \& D. Hearne, Our Brother's KeEper: The Indian in White AMERICA 68 (1970).

sso Id:

s31 See supra notes $268-78$ and accompanying text.

ss2 S. Steiner, The NeW INDIANS 277 (1968). 
Nevertheless, the importance of a right does not bridge the gap between procedural protection and heightened judicial scrutiny of legislation affecting that right. Advocates must also distinguish aboriginal property from other property accorded only procedural protection. For example, the decisions that the petitioners in Goldberg and Perry could not be deprived of their welfare and university employment without notice and an opportunity to be heard have not been held to mean that the state could not eliminate all welfare or close the state university unless necessary to effectuate a compelling interest. Such a result might paralyze government, for statutorily granted or customarily earned benefits, once created, could never be eliminated absent the necessity to accomplish some overriding interest.

If Indian rights to aboriginal land were analogized to an ongoing entitlement akin to welfare or employment, the government might have the right to cut off those benefits altogether, even absent any compelling purpose. The analogy is flawed, however. Aboriginal land is not rightly to be equated with other governmental largess, to be granted or withheld depending on the fiscal needs of the time and the shifting political ideologies of the majority. Given the Nonintercourse Act, the repeated promise to protect Indian property from confiscation, ${ }^{333}$ and the centuries old history of use and occupancy, the interest in aboriginal land is better analogized to a vested property interest. Intrusion on that interest would be much as if the government had demanded the return of all previous payments made to a welfare mother or prior salary paid to a university professor.

\section{Recognized Title Land}

\section{a. Recognized Title and the Takings Clause}

Unlike tribes whose claims are based on aboriginal title, other tribes possess recognized title, property granted by Congress within the meaning of the Tee-Hit-Ton rule and thus qualifying as "property" under the fifth amendment takings clause. Yet, even tribes holding such title lack the full protection of the takings clause, for they are subject to a special rule defining certain situations as not being fifth amendment takings. Ordinarily, when the government diminishes the value of property, the courts balance the detrimental economic effect of the regulation against the public good to be furthered by the regulation to determine whether a taking has occurred..$^{334}$ Moreover, in 1982, the court 
adopted a per se rule: whenever government effects a "permanent physical occupation" of property, there is a taking without a need to balance. ${ }^{355}$ Despite this per se rule, whether a taking of Indian recognized title has occurred depends on the source of the congressional power exercised. If the Court finds the government acted as a guardian of Indian land in transmuting the land into money, even against the wishes of its Indian tribal ward, a taking has not occurred. Rather, a taking occurs only when the government has acted as a sovereign, taking the land in an eminent domain sense. ${ }^{\text {s36 }}$

In United States $v$. Sioux Nation, ${ }^{337}$ the Court reaffirmed this principle, adopting a test for determining the source of the power exercised in a given case. If the government "fairly (or in good faith) attempt[ed] to provide [its] ward with property of equivalent value,"33s the government acted as guardian; its guardianship role then insulates it from liability. The Supreme Court's adoption of this test in Sioux Nation did no harm to the tribal claimant, because the Court held the seizing of the Black Hills to be a taking. ${ }^{339}$ Nevertheless, in earlier Court of Claims cases applying essentially the same rule stated in Sioux Nation, the government was held to be not liable for taking Indian reservation land against tribal consent and selling it to non-Indians when it attempted in good faith to provide compensation to the tribe. ${ }^{340}$ Thus, despite the supposed demise of the Plenary Power Doctrine, the government's position as guardian of Indian tribes can still be used to immunize it from liability under specific constitutional guarantees. ${ }^{341}$

(1978).

385 Loretto v. Teleprompter Manhattan CATV Corp., 458 U.S. 419, 426, 434-35 (1982).

ss6 United States v. Sioux Nation of Indians, 448 U.S. 371, 409 n.26, 416-17 (1980); Fort Berthold Reservation v. United States, 390 F.2d 686, 691-93 (Ct. Cl. 1968). See generally Newton, The Judicial Role in Fifth Amendment Takings of Indian Land: An Analysis of the Sioux Nation Rule, 61 ORE. L. Rev. 245 (1982). 337448 U.S. 371 (1980).

sss Id. at 416 (quoting Sioux Nation of Indians v. United States, 601 F.2d 1157, 1162 (Ct. Cl. 1979)).

${ }^{339}$ See id. at 424.

s40 Compare, e.g., Klamath \& Modoc Tribes v. United States, 436 F.2d 1008 (Ct. Cl. 1971) (good faith present; Congress set up fair appraisal system and attempted to get fair market value for the tribes) with, e.g., Confederated Salish and Kootenai Tribes v. United States, 437 F.2d 458 (Ct. Cl. 1971) (good faith absent; some lands granted to third parties without appraisal, other land opened to settlement without tribal consent, and proceeds used for irrigation project benefiting non-Indians as well as the tribe).

${ }^{341}$ A recent comment bases a framework for analyzing federal power on the approach used in Sioux Nation, arguing that when the government uses its guardianship power, a court should review its action under the minimal rationality standard of review, but that when the government action is adverse to Indian interests, courts should consider imposing limitations on federal power to protect Indian rights. See Comment, supra note 228. The author of that comment suggests criteria to be employed by a 
In sum, the fifth amendment takings clause affords less protection for Indian land than for other land. All tribal property-aboriginal, recognized, and even fee simple absolute title land-is held in trust by the United States and is subject to the government's guardianship power. ${ }^{342}$ When exercise of this guardianship power results in loss of tribal land, the application of the Sioux Nation rule could deny a constitutional remedy to Indian tribes. Concededly, an injured tribe may still recover the fair market value by suing for breach of trust in the Gourt of Glaims. The guardianship relationship, however, the circumstances under which it imposes duties on the government, and its termination are not anchored in the Constitution, but are subject to the caprice of Congress. ${ }^{343}$

\section{b. Due Process and Recognized Title Land}

The federal government continues to assert a guardianship power to manage all Indian property, even recognized title property. Tribes must thus obtain approval before spending tribal funds in certain circumstances, ${ }^{344}$ granting rights of way, or leasing tribal land. ${ }^{345}$ With regard to recognized title property, it must be argued that due process protection, like takings clause protection, should be extended to property held under a treaty or statute, and the due process clause should be used to challenge the government's unchecked management of tribal land.

As an important prerequisite to this challenge, tribal advocates must overcome the plenary power era statement that Indian property is not private property but public property. ${ }^{348}$ The little case law available demonstrates that whenever the Court views Indian property as private property, it has not hesitated to extend the Constitution's protec-

court in determining whether an action is adverse, including the obvious effect of the statute, the opinions of the affected tribes as to the effect, whether the statute abrogates a treaty, and whether Congress has responded to non-Indian pressures. Id. at 259-63. Another position is that taken by the author of this Article, that Congress should not gain the benefit of the Sioux Nation rule unless the tribe has consented to the action in question. See Newton, supra note 336, at 264.

s42 See 1982 HANDBOoK, supra note 3, at 471-73.

34s See United States v. Mitchell, 445 U.S. 535 (1980) (existence of fiduciary relationship turns on congressional intent); Menominee Tribe v. United States, 677 F.2d 90 (Ct. Cl. 1982) (court cannot question congressional statute denying it jurisdiction over nonconstitutional breach of trust claim). See generally Newton, Enforcing the Federal-Indian Trust Relationship After Mitchell, 31 GATH. U.L. REv. 635 (1982).

s4t See 25 U.S.C. $\S \S 121-125$ (1976).

345 See 25 U.S.C. $\S \S 311-328$ (1976).

s48 See, e.g., Starr v. Long Jim, 227 U.S. 613, 625 (1913); Cherokee Nation v. Hitchcock, 187 U.S. 294, 307-08 (1902). 
tions. The most notable example is Choate $v$. Trapp, ${ }^{347}$ decided at the height of the plenary power era. In Choate the Court held that a statutorily created tax exemption contained in allotment patents made to members of the Choctaw and Chickasaw Nations was a vested right protected by the due process clause from abrogation by a later statute. ${ }^{348}$ A contractual analysis was central to the Court's conclusion: by relinquishing their claims to tribal fee simple land, the tribes provided consideration for the grant of the allotments and imposition of a tax exemption on the allotted land. Individual Indians accepted the offer by giving up their claims and accepting the patents. Once the patents were delivered, the agreement became executed, and the property rights vested. ${ }^{349}$

The many Indian tribes who ceded land to the United States, reserving a portion or receiving new land in return, should argue that their land claims must be treated as vested property rights based on contractual agreements with the federal government. ${ }^{380}$ Such an argument could have far-reaching implications. First, confiscation of recognized title property would require compensation, but Tee-Hit-Ton already established that fact. More important, although Lone Wolf permits abrogation of sovereign responsibilities under treaties, it could be argued that abrogating a treaty provision reserving land would impair vested contractual rights in violation of the due process clause. By analogy to the Court's recent cases interpreting the contract clause, ${ }^{351}$ tribal advocates could argue that confiscation of tribal property should not be permitted unless it was "both reasonable and necessary" to serve "important purposes"352 which could not be satisfied by less drastic alternatives. $^{\text {s53 }}$ The Burger Court's recent willingness to impose this heightened standard of review ${ }^{\mathbf{3 5 4}}$ on states' impairment of public contracts ought to be imposed on the federal government's agreements with Indian tribes as well.

In short, when reviewing government abrogation of treaty promises and confiscation of tribal land, courts should apply more than the minimal rationality invoked in economic rights cases. Indian tribes

347 224 U.S. 665 (1912).

s48 Id. at $677-79$.

s49 Id. at 671-72.

sso See Clinton, Indian Autonomy, supra note 228, at 1031.

${ }^{351}$ E.g., United States Trust Co. v. New Jersey, 431 U.S. 1 (1977); see Allied Structural Steel Co. v. Spannaus, 438 U.S. 234 (1978).

ss2 United States Trust Co. v. New Jersey, 431 U.S. 1, 29 (1977) (plurality).

sss Id. at 30.

ss4 See Schwartz, Old Wine in Old Bottles? The Renaissance of the Contract Clause, 1979 Sup. Cr. REv. 95, 108. 
are not businesses, but entities with ancient claims to tribal land. Their treaties with the government are not merely business contracts, but agreements having far deeper implications for their survival as a people. Their tribal land is their heritage and not simply an economic unit. Its preservation is an essential condition to preservation of tribal culture. ${ }^{355}$ One need not prejudge the outcome of challenges to governmental infringement on tribal property interests to conclude that the outcome should not be determined solely in the crucible of majoritarian politics and on the basis of analyses developed to protect only economic endeavors. Whatever the proper accommodation in a given case, the role of the courts should not be merely to yield to legislative will as if the values at issue were no different than the elimination of pushcart vending in the Vieux Carré of New Orleans. ${ }^{356}$

\section{Retroactive Legislation and Accrued Claims}

Until now the takings clause has not proven to be an effective shield against government interference with tribal property. Some recent cases, however, suggest that tribal advocates should begin to reconsider the takings clause as it applies to retroactive legislation and accrued claims. When legislation infringing tribal property interests implicates other due process values which have in the past caused nonIndian legislation to be subjected to more than minimal scrutiny, the courts ought to apply heightened scrutiny in reviewing the Indian legislation.

One notable example of such legislation is the Alaska Native Claims Settlement Act which retroactively extinguished both aboriginal title to Alaskan land and all claims based on aboriginal title. ${ }^{367}$

While Congress has not recently extinguished aboriginal title, during the Ninety-Seventh Congress a bill was introduced to extinguish retroactively Northeast Indian tribal claims to land in New York, Connecticut, and South Carolina. ${ }^{358}$ These states had purchased tribal land in violation of the Doctrine of Discovery and the Nonintercourse Act, which prohibit alienation without consent of the United States. ${ }^{369}$ Accordingly, the tribes alleged that these sales were void. Although the

sos See supra notes $329-32$ and accompanying text.

sse See New Orleans v. Dukes, 427 U.S. 297, 303 (1976) (regulation of pushcart vendors being solely economic, need only be "rationally related to a legitimate state interest").

36743 U.S.C. $§ 1603$ (1976).

ss8 Ancient Claims Settlement Act of 1982, S. 2084, 97th Cong., 2d Sess. (1982).

s59 See supra notes 24-25 and accompanying text (Nonintercourse Act); 64-68 and accompanying text (Doctrine of Discovery). 
largest of these claims, that involving most of present-day Maine, has been settled, ${ }^{360}$ the remainder continue to cloud the titles of landholders in the affected areas. ${ }^{361}$ The law would have extinguished retroactively aboriginal title to the land and any claims accrued based on title (such as trespass claims). ${ }^{\mathbf{6 2}}$ Although the proposed law provided for some compensation, ${ }^{363}$ it has been argued by the Solicitor for the Department of the Interior, among others, that Congress has the power to extinguish these claims without violating the takings clause or the due process clause. ${ }^{364}$

s60 Maine Indian Claims Settlement Act, 25 U.S.C. $\S \S 1721-1735$ (Supp. V
1981).

s61 The legislation would extinguish claims based on recognized title as well. Most of the claims are based on aboriginal title, however. See Vollmann, A Survey of Easterm Indian Land Claims: 1970-1979, 31 ME. L. REv. 5, 6 (1979). The largest remaining claim is the Oneida claim. See Oneida Indian Nation v. County of Oneida, 434 F. Supp. 527, 530 (N.D.N.Y. 1977), aff'd, 719 F.2d 522 (2d Cir. 1983) (defendants liable for rental value on the portions of 100,000 acres in central New York they used and occupied); see also Oneida Indian Nation v. County of Oneida, 622 F.2d 624, 625-26, $625 \mathrm{n.3}$ (2d Cir. 1980) (history of Oneida claims based on aboriginal land). In addition, the Oneida tribe has made a claim to six million acres in New York, arguing that state treaties signed before the Nonintercourse Act was enacted in 1791 are void because entered into without federal consent as required by the Doctrine of Discovery and the Articles of Confederation. Oneida Indian Nation v. State of New York, 691 F.2d 1070 (2d Cir. 1982) (reversing lower court dissmissal, and remanding for further proceedings).

${ }_{382}$ S. 2084, 97th Cong., 2d Sess. $§ \S 4(a), 4(c)$ (1982). Claims barred included "all actual or theoretical claims against the United States, any State . . . or any other person or entity. . . arising at the time of or subsequent to the transfer and based on any interest in . . . such land or natural resources, including . . . claims for trespass damages, mesne profits, or claims for use and occupancy." Id. $\S 4(\mathrm{c})$. All claims are "deemed extinguished as of the date of such transfer." Id.

${ }^{363}$ The bill provided that suit for money damages in the Court of Claims be the exclusive remedy for the claims. Id. $\S 6($ a). Damages would have been measured by the fair market value of the land at the date of the original transfer less any money the tribe actually received from the states. $I d$. $\S 6(\mathrm{c})(1)$. Tribes proving they owned recognized title at the date of transfer would have been entitled to $5 \%$ simple interest from the date of transfer; those claiming aboriginal title would have been limited to $2 \%$ simple interest. $I d$. $\$ \S 6(\mathrm{c})(2)(\mathrm{i})$-(ii).

sot The present administration took the position that retroactive extinguishment of aboriginal title as well as claims based on aboriginal title do not offend the Constitution. In statements made to the Senate Select Committee on Indian Affairs, the Solicitor for the Department of the Interior stated, "While there may be a constitutional obligation to compensate for retroactive ratification of transfers of recognized title, there is no such requirement with respect to aboriginal title." Statement of William H. Coldiron, Solicitor, supra note 223, at 28. Thus, the Department of the Interior recommended that no compensation be provided for the aboriginal land extinguished by the legislation. The Department of Justice agreed in its statement before the same committee. The department argued against any compensation for aboriginal title: "[T]here is clearly no such requirement with respect to aboriginal title. Moreover, compensation for aboriginal title might create an irresistible legislative precedent which could prove extremely expensive." Ancient Indian Land Claims: Hearing Before the Select Committee on Indian Affairs, 97th Cong., 2d Sess. 37 (1982) (Statement of Carol E. Dinkins, Assistant Attorney General, Land and Natural Resources Division, Depart- 
Retroactive legislation, action affecting preenactment rights, has, however, traditionally been subjected to more than minimal scrutiny to determine whether it violates due process. ${ }^{365}$ Moreover, some members of the Court have exhibited special concern when the retroactive legislation was designed to eliminate takings claims: "[A] State cannot be permitted to defeat the constitutional prohibition against taking property without due process of law by the simple device of asserting retroactively that the property it has taken never existed at all."36e In addition, the Court has, in a case predating the Lochner era, held that retroactive legislation extinguishing accrued legal claims violates due process. ${ }^{367}$ Because of this suspicion of retroactive legislation, a District

ment of Justice).

The American Land Title Association has prepared and circulated a lobbying brief arguing that retroactive extinguishment of both aboriginal and recognized title is constitutional even if no compensation is paid the affected tribes. See INDIAN LAND GLAIMS, supra note 223, at 55-61 (aboriginal title), 85-90 (recognized title). The success of this lobbying effort may be reflected in the similarity between language employed in the model statute provided in the American Land Title brief and the language employed in the bill, as well as in legislation ratifying agreements settling the Maine and Rhode Island claims. Compare id., Model Statutory Language to Clear Titles of Indian Claims (appendix) with S.2084, 97th Cong., 2d Sess. \$ 4 (1982) and Maine Indian Claims Settlement Act, 25 U.S.C. \& 1723(a)(1), (b)-(c) (Supp. V 1981) and Rhode Island Indian Claims Settlement Act §§ 6, 13, 25 U.S.C. §§ 1705, 1712 (Supp. V 1981).

${ }^{3 e s}$ See Leedom v. International Bhd. of Elec. Workers, Local Union No. 108, 278 F.2d 237, 240 (D.C. Cir. 1960); see also Hochman, The Supreme Court and the Constilutionality of Retroactive Legislation, 73 HARv. L. REv. 692, 697 (1960) (courts should and do balance "the nature and strength of the public interest served by the statute, the extent to which the statute modifies or abrogates the asserted preenactment right, and the nature of the right which the statute alters."). See generally Greenblatt, Judicial Limitations on Retroactive Civil Legislation, 51 Nw. U.L. REv. 540, 554, 561 (1956) (courts should consider the reasonableness of legislative objectives and balance them against the asserted private right); Slawson, Constitutional and Legislative Considerations in Retroactive Lawmaking, 48 CALIF. L. REv. 216, 251 (1960) (courts should and do consider factors normally associated with substantive due process, such as protection from irresponsibility of governmental officials and protection from punishment "for choices made without knowledge of their wrongful character").

${ }^{383}$ Hughes v. Washington, 389 U.S. 290, 296-97 (1967) (Stewart, J., concurring); see also Forbes Pioneer Boat Line v. Board of Comm'rs, 258 U.S. 338 (1922) (retroactive ratification of illegally collected tolls impermissible). There is precedent, although limited, for upholding retroactive ratification of a fifth amendment taking in Indian law, however. Shoshone Tribe v. United States, 299 U.S. 476 (1937). In Shoshone Tribe, the Supreme Court held that the United States government had ratified an illegal taking of Indian land accomplished by government agents. Id. at 495. Although the effect of this ruling was to set the date for the measure of fair market value as of the time of the illegal action, rather than the time of the ratification, this analysis still resulted in an imposition of liability on the government and not an abrogation of government liability, as would be the case in the Alaska Native Claims Settlement Act, 43 U.S.C. § 1603 (1976). Furthermore, the concept of ratification of third parties' illegal acts as a justification for retroactive legislation has been criticized. See, e.g., Greenblatt, supra note 365 , at 704.

${ }^{367}$ Ettor v. City of Tacoma, 228 U.S. 148 (1913). Ettor involved the repeal of an 
of Columbia decision construed portions of the Alaska Native Claims Settlement Act as not extinguishing accrued claims in order to avoid an interpretation that would raise the possibility of constitutional infirmities in the Act. ${ }^{388}$

While the Supreme Court has not directly addressed the issue of accrued claims and the takings clause, in the Iranian Assets Case, Dames and Moore v. Regan, ${ }^{369}$ several justices recently commented in dicta that a taking of accrued claims might subject the government to fifth amendment takings clause liability. ${ }^{370}$ Thus, although the Supreme Court has held aboriginal title not to be property protected by the takings clause, it could conceivably still find accrued claims based on that same aboriginal title-claims for trespass and breach of trust, for instance-to be property for purposes of the takings clause.

Despite the dictum in Dames and Moore the Court of Claims recently invoked the political question doctrine in holding that the Alaska Native Claims Settlement Act provision extinguishing claims based on aboriginal title did not require compensation. Congress "made a political decision not subject to judicial reexamination. Congress's authority to extinguish aboriginal title without payment also authorized it without payment to extinguish the trespass claims based upon that title."371 Not surprisingly, Tee-Hit-Ton was the primary case law the Court relied on. ${ }^{372}$ If the Supreme Court addresses this issue again in the context of the Iranian settlement, and holds accrued claims to be property for takings clause purposes, the consequences will be great for tribes

ordinance that granted property owners a cause of action for consequential damages as a result of street grading. The Court found a due process violation when the City, in repealing the ordinance, applied the new law retroactively to extinguish claims accruing before the repeal. Id. at 150, 156; $c f$. Coombes v. Getz, 285 U.S. 434 (1932) (contract clause invalidates retroactive legislation affecting contract rights).

${ }^{368}$ Edwardsen v. Morton, 369 F. Supp. 1359, 1379 (D.D.C. 1973) (claims accruing before the date of the Settlement Act were "vested property rights protected by the Fifth Amendment"). Contra United States v. Atlantic Richfield Co., 612 F.2d 1132 (9th Cir.) (Settlement Act extinguished all claims based on aboriginal title, including trespass claims), cert. denied, 449 U.S. 888 (1980); Inupiat Community v. United States, 680 F.2d 122 (Ct. Cl.) (Settlement Act's extinguishing of tribal trespass claims did not violate fifth amendment takings clause), cert. denied, 103 S. Ct. 299 (1982).

se8 453 U.S. 654 (1981); of. Persinger v. Islamic Republic, 51 U.S.L.W. 2243 (D.C. Cir. Oct 8, 1982) (Bork, J.) (upholding power to extinguish claim for damages by hostages against Iran).

370453 U.S. at 689; id. at 690 (Powell, J., concurring \& dissenting in part). The issue of accrued claims was held not ripe for review by a majority of the Court. Id. at 689.

${ }^{371}$ Inupiat Community v. United States, 680 F.2d 122, 129 (Ct. Cl.), cert. denied, 103 S. Ct. 299 (1982).

${ }^{372}$ Id. at $129-30$. 
facing the threat of retroactive legislation that eliminates accrued claims.

\section{The Due Process Clause and Sovereignty}

Arguments favoring constitutional protection for property, while far from certain, are easier to advance than those favoring the same degree of protection for tribal sovereignty. As demonstrated above, the more a court is willing to view Indian property as private property, the more willing it might be to extend constitutional protection to that property.

Reconciling protection of tribal sovereignty with the individual rights approach of the Bill of Rights is more challenging. Nevertheless, it has been argued, chiefly by Barsh and Henderson, ${ }^{373}$ that tribal sovereignty should be protected as a fundamental political liberty. Their argument rests on sovereignty as a retained right of the people under the ninth amendment. ${ }^{374}$ The due process clause's protection of liberty, however, would be a more secure, even if less logical, ${ }^{375}$ repository for this right. In a recent case, Washington $v$. Confederated Bands and Tribes of the Yakima Indian Nation, ${ }^{376}$ a tribe relied on the due process clause to challenge congressional action infringing its sovereignty; unfortunately, the Supreme Court refused to countenance the argument and stated: "The contention that [the congressional action in question] abridges a 'fundamental right' is also untenable. It is well-established that Congress, in the exercise of its plenary power over Indian affairs, may restrict the sovereign powers of the Indian tribes."377

Nevertheless, tribal advocates should not accept this dismissal as decisive. As discussed previously, tribes can rely on the apportionment clauses and the Indian commerce clause to argue that Indian tribes on tribal land have some rights of local self-government that have been recognized by the Constitution and cannot be infringed by government, at least not without an overriding justification. ${ }^{378}$ Yet, the sufficient

373 R. BARSH \& J. Henderson, supra note 12, at 257-69.

374 Id. at 266-67.

378 See J. ELY, supra note 233, at 34-41.

376 439 U.S. 463 (1979), discussed infra text accompanying notes 501-19.

377439 U.S. at 501.

378 The historical evidence supporting an intention to protect Indian tribal sovereignty would, of course, bolster this argument. Indeed, the Supreme Court has recognized that tribes have the power to determine membership for internal purposes, see Santa Clara Pueblo v. Martinez, 436 U.S. 49 (1978); to tax their own members as well as outsiders doing business on the reservation in certain circumstances, see, e.g., Merrion v. Jicarilla Apache Tribe, 455 U.S. 130, 144 (1982); Washington v. Confederated Tribes of the Colville Indian Reservation, 447 U.S. 134, 152-54 (1980), and to pass local ordinances affecting internal matters, see, e.g., Fisher v. District Court, 424 U.S. 
case for due process protection of tribal sovereignty requires more. As Justice Powell stated in Moore v. City of East Cleveland: "Appropriate limits on substantive due process come not from drawing arbitrary lines but rather from careful 'respect for the teachings of history [and] solid recognition of the basic values that underlie our society.'

One such value is the "morality of promise-keeping."380 $\mathrm{Mr}$. Justice Black expressed this value most eloquently: "Great nations, like great men, should keep their word." 381 The Constitution protects this value in the contract clause and the Court has, in the past, incorporated this value into the law regulating Indian affairs. ${ }^{382}$ More fundamentally, the morality of promise-keeping is "implicit in the concept of ordered liberty." "sss It is the foundation of the law of contracts; tort law, too, protects promises from malicious interference. Beyond cavil, one value "basic in our system of jurisprudence"384 is that a deal is a deal.

That this value has not always been honored in the history of American treatment of Native tribes hardly excuses its continued violation. Although treaties with Indian tribes over the years have varied significantly, many have promised government recognition and protection of tribal sovereignty. ${ }^{385}$ While the last-in-time rule permits abrogation of the promises made in the international arena, ${ }^{\mathbf{3 8 6}}$ the need to maintain an international reputation for keeping the nation's word and

382,389 (1976) (tribal court has exclusive jurisdiction over adoption proceedings). See generally 1982 HANDBOOK, supra note 3, at 246-57.

Nevertheless, while recognizing the existence of tribal sovereignty, the courts continue to maintain that all self-government can be abrogated at the whim of Congress. See supra notes 206-210 and accompanying text. Furthermore, the tribes themselves continue to concede this point, arguing instead that the particular statute at issue did not in fact abrogate tribal sovereignty. See, e.g., Crain v. First Nat'l Bank, 324 F.2d 532, 535 (9th Cir. 1963); of. Yavapai-Prescott Indian Tribe v. Watt, 707 F.2d 1072 (9th Cir. 1983) (argument in favor of tribal authority to cancel leases based solely on congressional intent expressed in statutes).

s70 431 U.S. 494, 503 (1977) (quoting Griswold v. Connecticut, 381 U.S. 479,

501 (1965) (Harlan, J., concurring)).

s8o See H. Wellington, Labor and the Legal Process 189 (1968).

381 Federal Power Comm'n v. Tuscarora Indian Nation, 362 U.S. 99, 142 (1960)

(Black, J., dissenting).

382 See, e.g., Choate v. Trapp, 224 U.S. 665 (1912).

383 Palko v. Connecticut, 302 U.S. 319, 325 (1937).

384 In re Oliver, 333 U.S. 257, 273 (1948).

s85 Typical is the promise to the Cherokee Nation quoted supra note 79; see also Clinton, Indian Autonomy, supra note 228, at $1028 \mathrm{n} .274$ (removal treaties); id. at 1029 n.275 (later treaties). Professor Clinton argues that even when land cessions by treaty did not contain such promises, the fact that the tribes would govern the reserved land was implicit. He maintains that "[w]hile it would be difficult to trace all Indian rights to express or implicit treaty provisions, it is nonetheless clear that federal Indian policy today is primarily the outgrowth of treaty guarantees of territorial integrity and tribal self-government." Id. at 1030.

${ }^{388}$ See supra text accompanying note 31. 
the availability of international forums in which the nation may have to justify its breach of promise are powerful incentives against invoking the last-in-time rule too frequently. Practical incentives once existed for keeping faith with Indian tribes as well: their aid was sought in fighting the British, ${ }^{387}$ and peaceful relations with tribes was believed essential to building this nation. ${ }^{388}$ Most of all, promises were made to induce Indian tribes to give up their land. Now that Indians comprise less than one percent of the population ${ }^{389}$ and Indian tribes are "domestic dependent nations" unable to avail themselves of the benefits accorded sovereign nations by international law, these practical incentives no longer function to restrain legislative action. Nevertheless, the promises were made, and tribes may fairly and strongly advance claims that these promises be honored. For the government to do otherwise violates an important tenet, deeply rooted in our legal traditions, that is designed to bond society by encouraging principled relations.

In addition, values fostering diversity in our pluralist society support tribal claims to sovereignty, for a tribe having governing powers over its own territory can better maintain a cohesive culture. The assimilationists recognized this link between tribal self-government and cultural identity, viewing the destruction of tribal government as essential to their civilization scheme. By destroying tribal governing structures, the assimilationists hoped to detribalize the individual Indians, preparing them to adopt the individualistic philosophy of that era. ${ }^{\mathbf{3 9 0}}$

It is not surprising that the assimilationist era in Indian law coincided with a period during which Americans accorded primacy to Anglo-Saxon cultures and values by restricting immigration and attempting to homogenize the populace. ${ }^{391}$ While the Supreme Court validated the Indian assimilationist legislation that came before it, the Court interposed itself against attempts to homogenize other beliefs and cultures. In the landmark cases of Pierce $v$. Society of Sisters ${ }^{\mathbf{3 9 2}}$ and Meyer $v$. Nebraska, ${ }^{38 s}$ the Court struck down state laws forbidding ed-

387 For a history of the Northeastern tribes' role in the American Revolution, see O'Toole \& Tureen, supra note 24; see also, F. PRUCHA, supra note 13, at 26-33. As Prucha points out, the British were more successful in obtaining Indians' allegiance. Nevertheless, some tribes, including the Oneida and Tuscarora Nations, remained loyal to the Colonists. For a discussion of the events leading up to the decision of the Six Nations Confederacy to fight with the British, see A. WALLACE, supra note 21, at 12544.

s88 See supra notes 20-22 and accompanying text.

389 See supra note 282.

390 See R. BERKHOFER, JR., supra note 19, at 170, 172.

so1 Id. at 177-78.

382268 U.S. 510 (1925) (successful challenges by religious and military schools to a state law compelling public school attendance by children age 8-16).

s83 262 U.S. 390 (1923) (invalidating a statute that barred the teaching of foreign 
ucation in parochial schools and outlawing instruction in foreign language in private schools. Although Pierce and Meyer were products of the Lochner era, their enduring value is illustrated by their frequent citation in the privacy and autonomy cases of the Warren and Burger courts. ${ }^{394}$

Justice McReynolds, writing for the majority in the two cases, denounced state attempts to "foster a homogeneous people"398. by treating children as "mere creature[s] of the State" zation. Thus, he found that the laws in question impermissibly interfered with the concept of liberty protected by the due process clause. ${ }^{\mathbf{3} 7}$ Concededly, Indian families now have the right to educate their children in reservation schools that impart the cultural values of the particular tribe. ${ }^{398}$ The precise holdings of Pierce and Meyer, therefore, may have little more to offer Indian tribes seeking to protect their sovereignty through the due process clause. Yet, the cases touch values more enduring than the protection of individual rights to acquire an education in a manner consonant with individual beliefs. As Laurence Tribe has argued, the statutes in Pierce and Meyer were aimed at suppressing Catholics in Oregon and Germans in Nebraska-groups unable "adequately to safeguard their interests through the political processes of their states." from forced homogenization demonstrates that values of cultural diversity may be protected by the Constitution in a proper case.

Even if one accepts that the Constitution protects cultural diversity, such protection need not, and cannot, be equated with a right to self-government for all diverse groups. To argue that the concept of liberty can be extended so far would encourage anarchy under the guise of pluralism. When a people form a constitutional government, they agree to relinquish some of their liberties in return for the protection against chaos provided by an ordered government, or so the founders believed. ${ }^{400}$ Thus, the Constitution's allocation of powers recognizes that self-government is a precious and limited resource that must not be unduly fragmented. ${ }^{401}$

languages before eighth grade).

s94 See, e.g., Roe v. Wade, 410 U.S. 113, 152-53 (1973); Griswold v. Connecticut, 381 U.S. 479, 482 (1965).

sas Meyer, 262 U.S. at 402.

306 Pierce, 268 U.S. at 535.

${ }^{397}$ See Pierce, 268 U.S. at 534-35; Meyer, 262 U.S. at 399-400.

${ }^{398}$ See 1982 HANDBOoK, supra note 3, at 694-96.

309 L. TRIBE, supra note $18, \S 15-6$, at 904.

100 See, e.g., The Federalist No. 2 (J. Jay); The Federalist No. 51 (J. Madison).

101 See The Federalist No. 51 (J. Madison). 
Neither the morality of promise-keeping nor the value of cultural diversity can create an absolute right to tribal sovereignty; nevertheless, these values can be raised to urge the courts to scrutinize strictly any attempt to dilute tribal sovereignty over tribal land and members. In Santa Clara Pueblo v. Martinez, ${ }^{402}$ decided in 1978, the Supreme Court gave effect to both of these values, although in the framework of statutory, rather than constitutional interpretation. Indian tribes, being neither states nor arms of the federal government, are not subject to the Bill of Rights, as the Court held in 1896 in Talton $v$. Mayes. ${ }^{403}$ In 1968, Congress passed the Indian Civil Rights Act ${ }^{404}$ to extend basic civil rights, in certain circumstances, to individual tribal members. The statute was invoked in Martinez by a member of the tribe who argued that the tribe's membership rules discriminated on the basis of gender and ancestry by denying membership to children of female members of the tribe who married outside the tribe while extending membership to children of similarly situated males. The United States District Court for the District of New Mexico denied Martinez injunctive and declaratory relief, holding that the tribal rule did not violate the Indian Civil Rights Act. ${ }^{405}$ The Tenth Circuit reversed, holding that the membership criteria did violate the statute's equal protection guarantee. ${ }^{408}$ To the surprise of many, the Supreme Court did not reach the merits. Rather, by narrowly interpreting the statute, the Court held that the Indian Civil Rights Act prescribed a rule of decision to be applied in tribal courts, ${ }^{\mathbf{4 0 2}}$ but did not explicitly waive tribal sovereign immunity. Therefore, suits could not be maintained against the tribe. ${ }^{408}$ In addition, the Court held that the law did not implicitly create a cause of action in federal court. ${ }^{100}$ The law's exclusive remedy was habeas corpus, the only remedy explicitly stated in it. ${ }^{\mathbf{1 1 0}}$

While the Court acknowledged Congress's power in Indian affairs, it manifested an extraordinary sensitivity to tribal sovereignty, stating that:

Even in matters involving commercial and domestic relations, we have recognized that "subject[ing] a dispute arising on the reservation among reservation Indians to a forum other

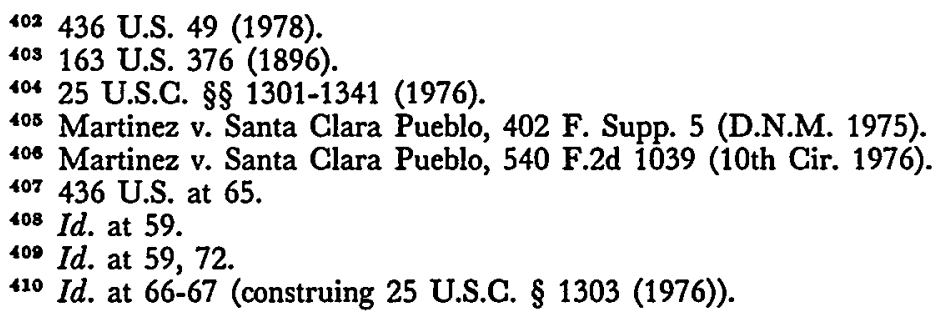


than the one they have established for themselves," may "undermine the authority of the tribal cour $[\mathrm{t}] \ldots$ and hence ... infringe on the right of the Indians to govern themselves." A fortiori, resolution in a foreign forum of intratribal disputes of a more "public" character, such as the one in this case, cannot help but unsettle a tribal government's ability to maintain authority. ${ }^{411}$

Accordingly, the Court interpreted the statute narrowly to accord "a proper respect both for tribal sovereignty itself and for the plenary authority of Congress in this area." ${ }^{412}$ Furthermore, in examining congressional intent, the Court stressed that Congress, in order to protect the "unique political, cultural, and economic needs of tribal governments," Bill of Rights to tribes.

Sensitivity to cultural diversity and acknowledgement of tribes as "separate sovereigns pre-existing the Constitution" 14 should impel the Court to accommodate the values of tribal sovereignty and federal power in cases in which Congress has not shown the sensitivity the Court lauded in Martinez. Nevertheless, the language supporting tribal sovereignty in Martinez was adumbrated by constant references to plenary power and the Court's limited role. For instance, at the end of the decision, the Court stated, with a citation to Lone Wolf: "As we have repeatedly emphasized, Congress' authority over Indian matters is extraordinarily broad, and the role of courts in adjusting relations between and among tribes and their members correspondingly restrained." 415

Tribal advocates must assert constitutional protections of tribal sovereignty and not concede plenary power. Invocations of Lone Wolf are a simplistic solution to the complex problem of accommodating tribal sovereignty and federal power. Reliance on Lone Wolf in the Martinez dicta may seem harmless. Yet, as Mr. Justice Jackson stated, in another context, referring to judicial opinions which validate the principle of racial discrimination, "The principle then lies about like a loaded weapon ready for the hand of any authority that can bring forward a plausible claim of an urgent need."416

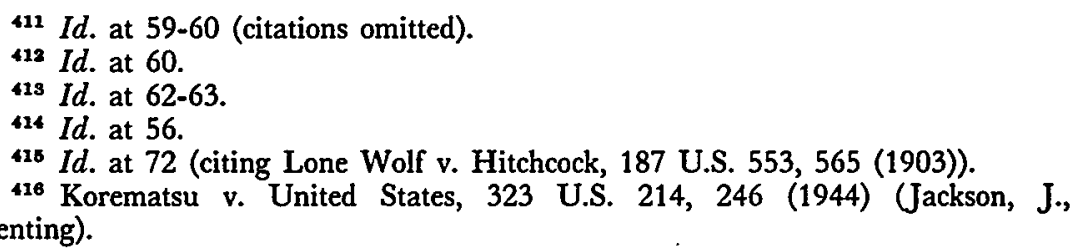
dissenting). 
As stated above, while due process arguments can and should be made, courts may not be receptive. ${ }^{417}$ The Burger Court's protection of fundamental values has been limited to privacy, autonomy, and recently to equality. Moreover, the values protected by the Burger Court have been values widely shared by a majority of Americans, ${ }^{418}$ and the Court's reasoning has frequently relied on appeals to tradition and consensus. ${ }^{419}$ The value of tribal sovereignty cannot be validated in this same fashion. If the tradition appealed to is the abstract one of local self-government, the answer is that the Constitution already protects local self-government by protecting state sovereignty. If the value sought to be protected is tribal sovereignty per se, neither tradition nor consensus of the majority of Americans supports maintenance of governing entities separate from the system of governance established by the Constitution. Only when other deeply rooted values that "underlie our society"420 and are shown to be basic to our system of jurisprudence are brought to bear can the sufficient case for due process protection of tribal sovereignty be made. The morality of promise-keeping and the values of cultural diversity explicated by the historical record of lawful tribal possession of sovereignty prior to the Constitution begin that sufficient case. By assiduously attempting to dismantle the loaded gun of Lone Wolf, Indian tribes may begin to safeguard their sovereignty from erosion should "any authority . . . bring forward a plausible claim of an urgent need [to eliminate it]."421

\section{E. Equal Protection Component of Due Process}

In contrast to due process, there is a growing body of case law regarding equal protection for Indians and Indian tribes. It will be discussed and analyzed in the next section of this Article. First, however, it will be useful to summarize briefly the framework of equal protection analysis, to demonstrate how tribal claims may qualify for the heightened judicial scrutiny available within that framework, and to uncover some hurdles Indian tribes may face when seeking to advance equal protection claims.

The framework of equal protection analysis is at once simple and

${ }^{112}$ Cf. Yakima Indian Nation, 439 U.S. at 500 (interest in tribal self-government not a fundamental right).

${ }_{18}$ See, e.g., Ely, The Supreme Court, 1977 Term-Foreword: On Discovering Fundamental Values, 92 HaRv. L. REv. 5, 12 (1978).

410 See id. at 39-52.

${ }^{420}$ Moore v. City of E. Cleveland, 431 U.S. at 503 (Powell, J.) (quoting Griswold v. Connecticut, 381 U.S. 479, 501 (1969) (Harlan, J., concurring)).

${ }^{421}$ Korematsu v. United States, 323 U.S. 214, 246 (1944) (Jackson, J., dissenting). 
complex. The Court has stated repeatedly that the equal protection component of the fifth amendment due process clause applies to the federal government with the same force as the fourteenth amendment equal protection clause applies to the states. ${ }^{\mathbf{4 2}}$ Moreover, as with due process claims, a tribe pressing an equal protection claim must attempt to invoke more than the minimal rationality standard appropriate to review of business ${ }^{423}$ and certain social welfare ${ }^{424}$ legislation. Otherwise, it is highly likely that the Court will simply defer to congressional action. ${ }^{425}$ Equal protection analysis, beyond minimal judicial review, provides two options: strict scrutiny, or a less rigid, intermediate standard of review. The former, first developed to provide heightened judicial scrutiny to discriminatory legislation based on suspect classifications, requires that those legislative classifications be subjected to the

422 " Equal protection analysis in the Fifth Amendment area is the same as that under the Fourteenth Amendment." "Delaware Tribal Business Comm. v. Weeks, 430 U.S. 73, 75 n.1 (1977) (quoting Buckley v. Valeo, 424 U.S. 1, 93 (1976)); cf. Hampton v. Mow Sun Wong, 426 U.S. 88, 100 (1976) (suggesting greater deference to federal legislation than to state legislation affecting aliens because of the "paramount federal power over immigration and naturalization").

${ }^{423}$ See, e.g., Lincoln Fed. Labor Union v. Northwestern Iron \& Metal Co., 335 U.S. 525, 536-37 (1949); United States v. Carolene Prods. Co., 304 U.S. 144, 152 (1938) (A court can generally assume "regulatory legislation affecting ordinary commercial transactions . . . rests upon some rational basis within the knowledge and experience of the legislators.").

424 See, e.g., Dandridge v. Williams, 397 U.S. 471, 484-87 (1970) (unsuccessful challenge to maximum grant under AFDC program as discriminating against large families).

${ }^{125}$ The Court's minimal scrutiny of equal protection claims has been as lenient as its scrutiny of due process claims, demonstrating the same willingness to hypothesize both about the permissible ends of the legislation and the relationship the legislative classification bears to those ends. "Legislatures are presumed to have acted constitutionally even if source materials normally resorted to for ascertaining their grounds for action are otherwise silent, and their statutory classifications will be set aside only if no grounds can be conceived to justify them." McDonald v. Board of Election Comm'rs, 394 U.S. 802, 809 (1969). Recently, however, certain Justices have evidenced a willingness to put some "bite" into equal protection review by requiring the state to articulate a purpose. In Logan v. Zimmerman Brush Co., 455 U.S. 422 (1982), the Court struck down a state mandatory time limit for consideration of employment discrimination complaints as violating procedural due process. Justice Blackmun, the author of the majority opinion, also submitted a separate opinion joined by three other Justices, stating his belief that the statute violated the equal protection clause as well, because the time limit classification had "so speculative and attenuated a connection to its goal as to amount to arbitrary action." Id. at 442 (Blackmun, J.). In addition, Justice Powell, in another separate opinion joined by Justice Rehnquist agreed that the challenged law violated equal protection. Id. at 444 (Powell, J.). See generally Gunther, The Supreme Court, 1971 Term-Foreword: In Search of Evolving Doctrine on a Changing Court: $A$ Model for a Newer Equal Protection, 86 HARv. L. REv. 1 (1972) (Gunther proposes an equal protection model requiring the Court to focus on the articulated purpose of statutes as well as to require a "genuine difference in terms of the state's objective between the group within the classification and those without." Id. at 47.). 
most rigid scrutiny ${ }^{\mathbf{4 2}}$ and be necessary to achieve a compelling or overriding governmental interest. ${ }^{\mathbf{4 2 7}}$ Intermediate scrutiny, applied when legislative classifications are not "suspect" but affect a disfavored class, requires that legislation bear a close and substantial relationship to an important governmental interest. ${ }^{\mathbf{4 2 8}}$

At the outset it must be recognized that an obvious hurdle, though one not yet addressed by the Court in the context of Indian tribal claims invoking the equal protection clause, is the applicability of strict scrutiny to collectives of racial minorities-Indian tribes-as opposed to the individual minority members comprising the tribe. From one perspective this is a novel constitutional issue since racial classification cases normally focus on discrimination against individuals. Yet associations are persons within the meaning of both the fourteenth and fifth amendment due process clauses, ${ }^{\mathbf{4 2 9}}$ and the Court has recognized explicitly that associations can assert both property and liberty interests. ${ }^{400}$ NAACP $v$. Button, ${ }^{431}$ perhaps, best demonstrates the Court's willingness to address the racially discriminatory implications of legislation directed at associations. In Button, the Court held invalid the application of a ban on the solicitation of legal business to the activities of the NAACP. The Court stated: "We cannot close our eyes to the fact that the militant Negro civil rights movement has engendered the intense resentment and opposition of the politically dominant white community of Virginia; litigation asserted by the NAACP has been bit-

428 E.g., McLaughlin v. Florida, 379 U.S. 184, 192 (1964).

${ }^{427}$ See id.; see also Loving v. Virginia, 388 U.S. 1, 11 (1967) (invalidating state ban on interracial marriages).

${ }^{428}$ Craig v. Boren, 429 U.S. 190, 197 (1976) (plurality) (invalidating exemption of females between 18 and 21 years of age from ban on selling $3.2 \%$ beer to males under the age of 21); see also Califano v. Westcott, 443 U.S. 76 (1979) (majority opinion applying Craig test to invalidate federal welfare regulation providing benefits to children of unemployed fathers but not unemployed mothers); cf. Plyler v. Doe, 457 U.S. 202, 224 (1982) (intermediate scrutiny applied to discrimination against undocumented aliens); Mills v. Habluetzel, 456 U.S. 91, 99 (1982) (intermediate scrutiny applied to discrimination based on illegitimacy).

429 Fullilove v. Klutznick, 448 U.S. 448 (1980) (association of contractors and a private firm challenged federal statute as violating equal protection); Williamson v. Lee Optical Co., 348 U.S. 483 (1955) (business corporation raised equal protection attack against state regulation); Railway Express Agency v. New York, 336 U.S. 106 (1949) (business corporation raised equal protection attack against state regulation).

4so First National Bank v. Bellotti, 435 U.S. 765, 780 (1978) (corporations can assert first amendment rights); see also Allied Structural Steel Co. v. Spannaus, 438 U.S. 234 (1978) (business corporation can assert contract clause rights); Marshall v. Barlow's, Inc. 429 U.S. 1347 (1977) (Rehnquist, J., in chambers) (business organization asserted privacy interests); Pollock v. Farmers' Loan \& Trust Co., 157 U.S. 429 (1895) (tax on business income violative of U.S. CoNST. art. I, $\$ \S 2,9$ ).

371 U.S. 415 (1963). 
terly fought." $\$ 42$ While the statute at issue arguably had a discriminatory purpose, as it was part "of the general plan of massive resistance to the integration of schools," tection issue, deciding the case instead on free speech grounds. ${ }^{434}$ Accordingly, Button cannot stand as unequivocal precedent for the proposition that discriminatory legislation against an association will receive strict scrutiny because the discrimination is aimed at discrete and insular minorities. Still, in 1980 the Court permitted associations of construction contractors and individual businesses to raise a reverse racial discrimination challenge to a federal law as violating the equal protection component of due process and accorded their claims more than minimal scrutiny. ${ }^{485}$ In Button, the Court was unwilling to "close [its] eyes" to the climate of "intense resentment and opposition of the politically dominant white community" that surrounded the NAAGP's constitutional attack. Similarly, there is no principled reason why, when Indian tribes raise equal protection challenges to legislation, the Court should close its eyes to the history of racial prejudice to which Indians have been subjected. The inherent value of heightened judicial scrutiny is that it may lead to restructuring or striking down legislative outcomes tainted by "prejudice against discrete and insular minorities."436 That value is honored no less when Indian tribes, rather than individual Indians, raise the spectre of prejudice.

The following section discusses the case law involving equal protection claims raised to challenge legislation affecting Indians. The analysis advanced will often depend on a reading of cases that goes beyond the express language of the opinions and will attempt to extrapolate from more subtle clues given by the Court. Unfortunately, the Court, while at first intimating the possibility of a higher standard of review for equal protection claims, especially those claims that disadvantage Indians, has gradually foreclosed many of the options left available in earlier opinions. The task of advocating a higher standard of review is, however, not futile. It is still possible to distinguish many of

132 Id. at 435.

43s Id. at 445 (Douglas, J., concurring).

434 Id. at 444-45.

488 Fullilove v. Klutznick, 448 U.S. 448 (1980). There was no opinion of a majority of the Court. Justice Burger's opinion, joined by Justices White and Powell, adopted no explicit standard of review, although it clearly imposed more than a mere rationality requirement on the legislation. Id. at 484-92. In a separate opinion, Justice Powell reiterated his belief that such programs require strict judicial scrutiny. Id. at 496. Justices Brennan, Marshall, and Blackmun reiterated their belief that intermediate scrutiny should be applied to such legislation. Id. at 519.

${ }^{438}$ United States v. Carolene Prods. Co., 304 U.S. 144, 152-53 n.4 (1938) (dictum); see also L. TRIBE, supra note 18, § 16-13, at 1012. 
the cases in a manner that would permit the Court, could it so be convinced, to take a more active role in scrutinizing legislation affecting Indians.

\section{Mancari and the "Tied Rationally" Standard of Review}

In Morton v. Mancari, ${ }^{437}$ decided by the Supreme Court in 1974 , the Court appeared to fashion a standard of review of legislation affecting Indians that had the potential to function as a limit on the government's guardianship power.

Mancari was decided at the height of the controversy over the constitutionality of state and federal programs designed to give preferences to racial minorities. The Supreme Court unanimously held that a Bureau of Indian Affairs (BIA) employment preference benefiting Indians did not violate the fifth amendment guarantee of equal protection. The Court upheld the preference because of the "unique legal status of Indian tribes." $"$ 4s8

This result at first seems surprising, for in the past the Court had treated racial classifications as nearly per se unconstitutional. ${ }^{439}$ The decision in Mancari, however, sidestepped the issue of racial classification. The Court held that the classification at issue was not a racial one because only those Indians belonging to federally recognized tribes could claim the benefit. ${ }^{\mathbf{4 0}}$ Indians whose tribes had been terminated or who had severed their tribal association could not claim the

437417 U.S. 535 (1974).

438 Id. at 551. In upholding the directive and the statute on which it was based, the Court frankly acknowledged that "literally every piece of legislation dealing with Indian tribes and reservations, and certainly all legislation dealing with the BIA, single out for special treatment a constituency of tribal Indians living on or near reservations." Id. at 552 .

4s9 The singling out of a race is "a brand upon them, affixed by the law, an assertion of their inferiority, and a stimulant to . . . race prejudice." Strauder v. West Virginia, 100 U.S. 303, 308 (1880). Consequently, the Court applies strict scrutiny to racial classifications. See supra notes 266-68 and accompanying text. When Mancari was decided, many thought that racial classifications conferring benefits rather than curtailing civil rights would be subject to equally rigid scrutiny. Since then, however, the Court has upheld at least one racial classification conferring benefits on historically disadvantaged minorities, although members of the Court continue to differ on the standards of review to be employed in such cases. Compare Fullilove v. Klutznick, 448 U.S. 448, 492 (1980) (Burger, C.J., White \& Powell, JJ.) (10\% minority set-aside of federal funds for local public works project would pass constitutional muster under either strict scrutiny or intermediate standard of review) with id. at 486 (Powell, J., concurring) (strict scrutiny is applicable standard) and id. at 519 (Marshall, Brennan \& Blackmun, JJ., concurring in the judgment) (intermediate standard of review is applicable standard). Contra id. at 523 (Stewart \& Rehnquist, JJ., dissenting) (strict scrutiny requires a holding that the statute is unconstitutional); $i d$. at 552-54 (Stevens, J., dissenting) (statute unconstitutional).

140 Mancari, 417 U.S. at 553 \& n.24. 
preference. $^{\mathbf{4 4 1}}$

Perhaps recognizing the racially discriminatory effect of the BIA preference, the Court evaluated whether the BIA action was motivated by a racially discriminatory motive. ${ }^{\mathbf{4 2}}$ The Court first examined the articulated purpose of the Indian Reorganization Act, which authorized the BIA preference, and concluded that it was designed to foster tribal self-government by permitting Indian tribes to reorganize their tribal governing structures as a first step to gaining control of their own affairs. ${ }^{433}$ In light of this congressional purpose, the Court determined that the intent of the employment preference was nonracial. Rather, it was "reasonably and directly related" to "further[ing] the cause of Indian self-government." 444 The Court concluded: "[A]s long as the special treatment can be tied rationally to the fulfillment of Congress' unique obligations toward the Indian, such legislative judgments will not be disturbed."445

Mancari broke important ground in Indian law. For the first time in the modern era, the Court attempted to fit Indian legislative classifications within the equal protection framework. First, the Court announced in dicta that Indian classifications are not inherently suspect, but permissible because the Constitution "singles Indians out as a proper subject for separate legislation."446 The main justification for permitting such classifications, however, was that they apply, for the most part, to tribal Indians, and are "political rather than racial in

441 This aspect of the Court's analysis can be criticized as disingenuous. The directive at issue in Mancari required a minimum blood quantum of one-fourth Indian blood in addition to membership in a federally recognized tribe. Consequently, an Indian whose federally recognized tribe required less than one-fourth blood quantum for membership could not take advantage of the directive solely because of his race. See Policy Review Commission Final Report, supra note 12, at 108-09 (a few tribes permit anyone descended from a tribal member to be enrolled, irrespective of blood quantum). A year later, a tribal member who did not meet the directive's blood quantum requirement challenged the directive. The government conceded that the Indian Reorganization Act's definition of Indian as "all persons of Indian descent who are members of any recognized Indian tribe," 25 U.S.C. $§ 479$ (1976), controlled over the directive's requirement of minimum blood quantum. Apparently the case was unreported. Whiting v. United States, Civ. No. 75-3007 (D.S.D. 1975), discussed in PoLiCy Review Commission Final Report, supra note 12, at 108-09.

${ }^{412}$ See Washington v. Davis, 426 U.S. 229 (1976) (showing of discriminatory purpose necessary to invoke strict scrutiny of a facially neutral statute).

443417 U.S. at 554.

444 Id. Stressing that a blanket preference for Indians in all branches of the civil service would raise more serious constitutional questions, the Court noted that the preference applied only to the BIA and that staffing the BIA with tribal members would tend to make the agency "more responsive to the needs of its constituent groups." Id.

$448 \mathrm{Id}$. at 555.

${ }^{448} I d$, at 552. 
nature,"447 involving "quasi-sovereign tribal entities."148 The Court has often repeated this latter point, and it remains a key factor in the justification for less than strict scrutiny of legislation regarding Indians. Second, although the Court used the phrase "tied rationally," the analysis in the opinion suggests that the Court actually applied more than minimal rationality scrutiny to the directive. For example, rather than simply assuming some hypothetical purpose, the Court first determined that Congress had the power to enact the Indian Reorganization Act and then isolated the articulated legislative purpose of the portion of the statute authorizing the BIA preference. The Court then found a close fit between the articulated statutory purpose and the means chosen to effectuate that purpose, pointing out that the preference applied only to the BIA, the agency charged with managing Indian affairs, instead of all federal agencies. ${ }^{\mathbf{4} 8}$

In sum, Mancari can be said to have at least intimated a heightened level of scrutiny for legislation benefiting tribal Indians. ${ }^{450}$ This scrutiny appeared to be triggered by the Court's determination that Congress undertook the preference policy as an exercise of its guardianship responsibilities. Having left Indians " 'an uneducated, helpless, and dependent people," Congress " "[o]f necessity . . . assumed the duty of furnishing that protection, and with it the authority to do all that was required to perform that obligation." "451 Whereas Kagama had held this guardianship authority to be extraconstitutional, in Mancari the Court stated it was "explicitly and implicitly [derived] from the Constitution itself."452

Some saw Mancari as the Court's signal that it would in the future "tame" the Plenary Power Doctrine of Kagama by viewing it as derived from guardianship duties and thus possibly limited to congressional actions benefiting Indians. ${ }^{453}$ Under this analysis, congressional action detrimental to Indian tribes could not be sustained unless it were based on some other enumerated power. Having reestablished the constitutional basis of congressional power over Indian affairs, the Court in Mancari may have been signaling an intent to assert its role as ulti-

417 Id. at 553 n.24.

448 Id. at 554.

140 Id.

450 See Johnson \& Crystal, Indians and Equal Protection, 54 WASH. L. REv. 587,599 (1979) ("something more rigorous than minimal scrutiny").

${ }^{151}$ Mancari, 417 U.S. at 552 (quoting Board of County Comm'rs v. Seber, 318 U.S. 705, 715 (1943)).

462417 U.S. at 551-52.

45s See 1982 HANDBOoK, supra note 3, at 221; see also Johnson \& Crystal, supra note 450 , at $626-27$. 
mate arbiter of the Constitution, both to define the extent of the amorphous Indian affairs powers and to require a close fit between statutory means and an express legislative purpose.

\section{Mancari's Progeny}

\section{a. Challenges by Individuals}

Mancari raised the possibility of a more active judicial role. Cases subsequent to Mancari have unfortunately ignored many of the signals of judicial activism in the Mancari decision and have cut back on the promise of that decision. Moe v. Confederated Salish and Kootenai Tribes, ${ }^{\mathbf{4 5 4}}$ the next case to raise an equal protection challenge, also involved a claim on behalf of non-Indians, in this case a claim that federal tax immunities for Indians are impermissible racial classifications. Without actually applying the Mancari test to the facts, the Court merely asserted that Mancari compelled the conclusion that the immunity was constitutional. ${ }^{455}$ The Court's failure to apply the Mancari test in $M o e$ did not necessarily signal a retreat from Mancari, but merely reflected the Court's belief that the fit between tax immunities and Congress's unique obligation was so obvious, that explanation was unnecessary. ${ }^{408}$

What is curious about Moe is that, as interpreted by the district court, the tax immunity applied to all Indians trading on reservation property, not only to members of a recognized tribe. ${ }^{457}$ Accordingly, unlike the legislation in Mancari, the classifications upheld in Moe were race-based. Yet the Court simply never addressed that issue, ${ }^{458}$ thus avoiding the need to follow the dictum in Mancari that the Constitution grants Congress the power to single "Indians out as a proper subject for separate legislation."

Both Mancari and Moe involved federal policies benefiting Indian

4 4S 425 U.S. 463 (1976).

${ }^{468}$ Id. at $479-80$.

4se The immunity of on-reservation Indian property and activities from state taxation has long been recognized by Congress and the courts. Tax immunity has been regarded as absolutely necessary to permit Indian tribes to maintain their land base, and in turn, their sovereignty. See generally Givil Rights Commission RePORT, supra note 27 , at $46-47$.

457425 U.S. at 481 n.16.

458 "The State has not challenged this holding, and we therefore do not disturb it." Id.

469417 U.S. at 552. Since Moe the Court has begun limiting tax benefits to tribal members rather than to Indians racially. Washington v. Confederated Tribes of the Colville Reservation, 447 U.S. 134 (1980). Thus, the Court appears to have recognized that racial classifications should be avoided in this area, at least. 
tribes and tribal members but disadvantaging non-Indians and nonmembers. The Court also applied the Mancari analysis in Fisher $v$. District Court, ${ }^{460}$ a case involving federal policies benefiting Indian tribes but disadvantaging tribal members. In Fisher, the petitioner, a member of the Northern Cheyenne Tribe, had lost custody of her child in a tribal court. When the child's guardian, also a tribal member, brought adoption proceedings in state court to gain permanent custody, the petitioner sought to block the state court form asserting jurisdiction. The Montana Supreme Court permitted the state court to assert jurisdiction, reasoning that a denial of state jurisdiction would deny Indians equal protection by depriving an Indian guardian of an advantage available to non-Indians. ${ }^{461}$ In reversing, the Supreme Court stated that Mancari controlled because the "exclusive jurisdiction of the Tribal Court does not derive from the race of the [guardian] but rather from the quasi-sovereign status of the Northern Cheyenne Tribe under federal law."462 Furthermore, the Court stressed that, as in Mancari, the federal policy was designed to benefit the entire class of which the guardian was a member "by furthering the congressional policy of Indian self-government."483 The occasional detriment to individual members, not being race-based, was therefore acceptable.

The analysis in Fisher closely tracked the judicial scrutiny analysis of Mancari. Rather than simply hypothesizing a purpose, the Court first emphasized the ample evidence of articulated federal intent to foster the self-government of Indian tribes. This intent was revealed both in an agreement and statutes regarding the Northern Cheyenne Tribe itself and in the Indian Reorganization Act's fundamental policy "to encourage Indian tribes to revitalize their self-government."464 Next, recognizing that a judicial system is a fundamental governmental organ through which self-government is exercised, the Court found a close relation between the tribal court system, established under the Indian Reorganization Act, and the furthering of Indian self-government. The Court then concluded that permitting individual tribal members to circumvent the tribal court system would cause a "decline in the authority of the Tribal Court"465 and hence in the exercise of tribal selfgovernment.

Delaware Tribal Business Committee v. Weeks, ${ }^{466}$ another case ap-

460424 U.S. 382 (1976).

481 State ex rel. Firecrow v. District Court, 167 Mont. 149, 536 P.2d 190 (1975).

462424 U.S. at 390.

sts Id. at 391 .

164 Id. at 387.

468 Id. at 388 .

468430 U.S. 73 (1977). 
plying the Mancari standard, is distinguishable from Mancari, Moe, and Fisher. Unlike Mancari and Moe, the controversy in Weeks involved only Indians; but, unlike Fisher, the interests of tribal and nontribal members were in conflict. The question in Weeks concerned entitlement to funds appropriated by Congress to fulfill a judgment for the Delaware Nation rendered against the United States by the Indian Claims Commission. ${ }^{\mathbf{1 6 7}}$ In the distribution scheme, Congress directed ninety per cent of the judgment to be distributed per capita solely to the Cherokee and Absentee Delawares. ${ }^{488}$ Consequently, the Kansas Delawares, members of the Delaware Tribe in 1854 when the treaty was made, were entitled to no money under the distribution scheme. Representatives of the Kansas Delawares obtained an injunction to block distribution of the funds on the ground that their exclusion violated the equal protection component of the due process clause. ${ }^{469}$ The Supreme Court reversed, applying the Mancari test. ${ }^{470}$

While the Court's application of the test was strictly in accordance with the "tied rationally" language of Mancari, it failed to apply the somewhat heightened level of scrutiny actually employed in Mancari. First, the Court turned the Mancari test on its head, citing it not as a source of limitation of federal power but as an example of the deference it owed to Congress in determining "the best or most efficient use for which tribal funds should be employed."471 Second, although in previous cases the Court had looked for an articulated legislative intent to further "Congress' unique obligation toward the Indian," in Weeks even the majority admitted that the exclusion of the Kansas Delawares was purely an oversight by Congress. ${ }^{472}$ Instead of relying on an articulated legislative intent, the Court conjectured that a possible congressional purpose underlying the discrimination against the Kansas De-

167 Absentee Delaware Tribe v. United States, 21 Ind. Cl. Comm'n 344 (1969).

The Claims Commission awarded the claimants $\$ 9,168,171.13$. Id. at 369-79.

188430 U.S. at $80-82$. court).

169 Weeks v. United States, 406 F. Supp. 1309 (W.D. Okla. 1975) (three judge

470430 U.S. at 85.

471 Id. at 84 (citing Sizemore v. Brady, 235 U.S. 441, 449 (1914)).

172 Id. at 89 . The original distribution act would have provided for per capita payments to all lineal discendents of the 1854 tribe. During hearings, the Cherokee and Absentee Delawares expressed concern that such broad language would invite the Munsee Indians, some of whom lived with the Delaware tribe in 1854 , to claim the right to share in the award. An earlier distribution plan had created just such a difficulty; the resulting claim by the Munsee Indians frustrated carrying out that distribution plan for years. In response to these concerns, Congress dropped the clause extending the plan to all lineal descendants. The measure designed to exclude Munsee Indians, who had not been a part of the 1854 Delaware tribe, excluded the Kansas Delawares in addition, leaving only the Cherokee and Absentee Delawares entitled. See 430 U.S. at $88-89$. 
lawares may have been to promote Indian self-government. ${ }^{473}$ Moreover, the Court ignored the tenuous link between the ascribed intent and the statutory scheme. Noting that the included groups had maintained their status as Indian tribes while the Kansas Delawares, in 1866, had elected to sever their tribal status and remained unorganized as a tribe, the Court concluded that the limitation of the judgment fund to present descendents who, for the most part, maintained tribal ties bore a reasonable relationship to promoting tribal self-government. ${ }^{\mathbf{4 7}}$ This reasoning, however, was unsound, since per capita awards, not tribal awards, were at issue. Per capita awards, while understandably popular with individual Indians, undermine tribal governments, which would be strengthened if the money were distributed to the tribal entity. ${ }^{475}$ Thus, the decision to award ninety per cent of the judgment to individual tribal members would have little positive impact on the congressional goal of furthering tribal self-government. Finally, the Court noted that Congress had deliberately excluded the Kansas Delawares from an earlier plan distributing money to pay for a judgment rendered in an earlier case. Thus, the Court concluded that Congress had "historically distinguished [the Kansas Delawares] from the Cherokee Delawares." $" 476$ This reliance on a past exclusion of the Kansas Delawares was specious, as Justice Stevens pointed out in dissent. ${ }^{477}$ The earlier exclusion was justified on the basis of a statute explicitly permitting only members of the Cherokee Tribe to bring a claim. ${ }^{478}$

The legislative history, however, did reveal one articulated purpose: to "avoid undue delay, administrative difficulty, and potentially unmeritorious claims"479 by excluding Indians who had not been members of the Delaware Nation in 1854. The Court, exercising heightened judicial scrutiny, normally does not accept administrative convenience as a justification for discrimination, especially where a more precisely tailored statute would not unduly burden effectuation of the legislative scheme. ${ }^{480}$ Furthermore, as Justice Stevens pointed out, the Kansas De-

473 See id. at 85-86.

474 Id. at 86.

176 Cf. A. Sorkin, American Indians and Federal Aid 145-46 (1971) (discussing divisive economics and effects of per capita awards).

478 U.S. at 87.

477 Id. at 95 (Stevens, J., dissenting).

478 Id.

$479 \mathrm{Id}$. at 89.

180 See, e.g., Wengler v. Druggists Mut. Ins. Co., 446 U.S. 142, 151-52 (1980) (gender discrimination); Orr v. Orr, 440 U.S. 268, 281 (1979) (gender); Hampton v. Mow Sun Wong, 42.6 U.S. 88, 115-16 (1976) (alienage); $c f$. Rostker v. Goldberg, 453 U.S. 57, 81-82 (1981) (need for military flexibility justified excluding all women from a draft when only 80,000 women could be employed in noncombat positions). 
lawares had shared in an earlier award with no difficulty. ${ }^{481}$ Thus, even accepting the purpose, the means used were unnecessarily broad.

In sum, the Court read Mancari as precedent justifying deference to congressional power; it speculated regarding congressional motives; and it required only a rational connection between legislative means and a hypothesized purpose. Thus, Weeks, while strictly applying the Mancari language, appears to be a significant retreat from the more stringent analysis actually applied in Mancari.

Nevertheless, several factors may explain the Court's deference in Weeks. First, as discussed above, the Court has been most deferential in cases involving congressional power to manage and distribute Indian property, land, or money. Second, the statute involved discrimination within classes of Indians, a point that is key to the majority's attitude toward this case. Whatever might impel Congress to exclude the Kansas Delawares, it could not have been racial discrimination. ${ }^{\mathbf{8 2}}$ Thus, the case becomes more like those in which the Court has reviewed categories of welfare aid and has hesitated to second-guess government decisions to draw a line at a particular place. ${ }^{\mathbf{4 8 3}}$

Although the deferential stance of Weeks could be limited as suggested above, the Court again deferred to Congress only a few months later in United States $v$. Antelope ${ }^{484}$ a case brought by individual Indians challenging on equal protection grounds legislation not designed to benefit Indians.

Ninety years before Antelope, in United States $v$. Kagama, ${ }^{485}$ the Court had upheld the Major Crimes Act, which subjects Indians who have committed certain crimes against other Indians to federal jurisdiction. ${ }^{486}$ In Kagama, it may be recalled, the constitutional argument centered mainly on the lack of congressional power to abrogate tribal

481430 U.S. at $95-96 \&$ n.7 (Stevens, J., dissenting).

182 Id. at 97 . Justice Stevens dissented not because the law was discriminatory, but because it deprived the Kansas Delawares of property without the "due process of lawmaking' that the Fifth Amendment guarantees." Id. at 98.

483 See, e.g., Dandridge v. Williams, 397 U.S. 471 (1970). It must be admitted that in the welfare context no entitlement exists among any class of recipients, whereas in the Weeks case the Kansas Delawares, as descendents of the 1854 Delaware Tribe, were at least as entitled as the other descendents. Nevertheless, whether any of the descendents of those wronged 100 years ago should be able to reap a windfall from actions the government took in the past has often troubled members of the Court. See, e.g., Northwestern Bands of Shoshone Indians v. United States, 324 U.S. 335, 355 (1955) (Jackson, J., concurring) (when wronged generation has gone, the present descendents might reap a windfall award). Thus, for instance, Justices Blackmun and Burger, though troubled about some aspects of the majority's analysis, still concurred in the result because "the argument on each side is not at all strong." 430 U.S. at 91.

484 U.S. 641 (1977).

${ }^{485} 118$ U.S. 375 (1886).

48B See supra notes 86-104 and accompanying text. 
sovereignty. ${ }^{487}$ In United States $v$. Antelope, however, the argument centered on individual rights. The defendants, tribal members convicted of murder in federal court under the Major Crimes Act, argued that the application of the federal felony-murder rule deprived them of equal protection because white persons committing the same crime at the same place would be subjected to the state's murder law, which would have required proof of premeditation. ${ }^{488}$ The Supreme Court rejected the defendants' constitutional arguments in an opinion ostensibly relying on Mancari, but in reality substantially undercutting Mancari as precedent for limiting congressional power.

To begin with, the Court cited Mancari for the proposition that legislation singling out Indian tribes does not represent a racial classification. ${ }^{489}$ The Court did not, however, apply the second part of the Mancari precedent: its test of the constitutional limits of federal legislation affecting Indians. Instead, it treated the issue of constitutional power to regulate tribal members as settled because of the absence of a racial classification. ${ }^{480}$ Moreover, the Court frankly acknowledged that the legislation in Antelope was not designed to further tribal selfgovernment as was the legislation in the Mancari line of cases. ${ }^{491} \mathrm{Nev}$ ertheless, it found in Mancari support for the broader conclusion that all federal legislation affecting tribal Indians is "governance" of Indian tribes $^{\mathbf{4 8 2}}$ rather than legislation of a "racial' group consisting of 'Indians." "483 In other words, the purpose of any legislation singling out Indian tribes appeared to be irrelevant to the Court, unless, of course, the legislation could be shown to have an invidious racial purpose. ${ }^{\mathbf{4 0 4}}$ Furthermore, the Court did not address whether the statute promoted interests consistent with the federal guardianship duty. To the contrary, it viewed all litigation affecting Indian tribes as "a necessary and appropriate consequence of federal guardianship under the Constitution."48s

Finally, while the Court did focus on tribal status, it managed to sidestep the serious issues raised by criminal laws, including the Major Crimes Act, that contain explicit racial classifications. The Antelope de-

487 See supra text accompanying notes 87-92.

188430 U.S. at 643-44.

189 Id. at 645 .

400 Id. at 646.

401 Id.

${ }^{402}$ Id.

${ }^{403}$ Id. (quoting Morton v. Mancari, 430 U.S. at 553 n.24).

484 See Washington v. Confederated Bands and Tribes of the Yakima Indian Nation, 439 U.S. 463 , 499 n.46 (1979).

495430 U.S. at 641,647 n.8 (emphasis added). 
fendants were tribal members, so the Court stated that it need not reach the question whether the Major Crimes Act applied to all Indians or only to some category of Indians such as tribal members or those living on a reservation and maintaining a close relationship with the tribe. $^{496}$ If the Major Crimes Act were interpreted as applying to all Indians, it would clearly create a race-based classification, not a tribal status classification as was found in Mancari. Moreover, unlike Moe, such a classification would possibly result in detrimental treatment of Indians because of their race. If the Major Crimes Act, so interpreted, were challenged by an Indian on equal protection grounds, the Court could hardly avoid, as it did in $M o e$, the thorny constitutional question of whether such a race-based classification could survive an equal protection challenge under strict scrutiny.

In sum, the Antelope Court announced that all legislation regarding tribal Indians had a legitimate governmental purpose: to govern Indian tribes. Furthermore, under an equal protection challenge, all such legislation would be permissible if not invidiously motivated and not irrational. ${ }^{497}$ After Antelope, therefore, it is difficult to conceive of a federal statute regarding Indian tribes, not motivated by racial discrimination, that could be found to violate the requirements of equal protection.

As was true of the earlier cases, however, it is possible to defend the result in Antelope, if not the reasoning. First, the defendants' argument raised no issues regarding the lack of governmental power to abrogate tribal sovereignty under the Major Crimes Act. Rather, the only issue raised was denial of equal protection as compared with similarly situated nontribal Indian persons-that is, those committing the same crime against the same victim on the reservation. To the Court, the defendants had misconceived the class to which they ought to compare themselves. In the absence of federal legislation, state courts would have no jurisdiction over the crime involved; tribal courts would have sole jurisdiction. Thus, "state law does not constitute a meaningful point of reference for establishing a claim of equal protection." ${ }^{\text {"98 }}$ The Court

${ }^{488} I d$. at $646-47$ n.7.

487 Id. at 647 n.8.

488 Id. at 649 n. 12 . This analysis presents something of a quandary for the defendants since they also could not compare themselves to similarly situated defendants in tribal court; the Major Crimes Act had removed that jurisdiction in 1885. Although the legislative history seems to suggest otherwise, lower federal courts and the Supreme Court have stated that the Major Crimes Act preempts concurrent tribal jurisdiction. See, e.g., Oliphant v. Suquamish Indian Tribe, 435 U.S. 191, 203 n.14 (1978) (dicta); Iron Crow v. Ogallala Sioux Tribe, 129 F. Supp. 15, 20 (D.S.D. 1955), affd, 231 F.2d 89 (8th Cir. 1956). For a review of the legislative history, see M. PRICE \& R. Clinton, Law and the American Indian 205-07 (1983). 
noted that the proper comparison class for the Indian defendants charged under the Major Crimes Act is the non-tribal Indian defendant charged under the criminal laws governing federal enclaves, such as military reservations. Since the Major Crimes Act incorporated this federal enclave law as the law to be applied to tribal Indian defendants, ${ }^{499}$ there was no discrepancy in treatment and hence no equal protection problem. "Under our federal system, the National Government does not violate equal protection when its own body of law is evenhanded, regardless of the laws of States with respect to the same subject matter."

\section{b. Challenges by Tribes}

Mancari, Moe, Fisher, Weeks, and Antelope all involved equal protection challenges raised by individuals. None, therefore, addressed the issue of equal protection claims raised by Indian tribes. Such a claim was presented to the Court in Washington $v$. Confederated Bands and Tribes of the Yakima Indian Nation. ${ }^{501}$ The tribes argued that state legislation extending criminal and civil jurisdiction over Indian reservations violated both their due process right to sovereignty and the equal protection clause. The Court ruled against the tribes on both claims in a decision marked by deference to congressional judgments regarding the continuing existence of tribal sovereignty. ${ }^{502}$

Public Law 280, ${ }^{\mathbf{5 0}}$ enacted by Congress in 1953, authorized states to assume criminal and civil jurisdiction over the Indian reservations within their borders, with or without the consent of the tribes involved. In 1963, the State of Washington assumed full jurisdiction over consenting Indian tribes but only partial jurisdiction over nonconsenting tribes. ${ }^{504}$ The assumption of partial jurisdiction depended on three factors: the status of the land on which the regulated conduct occurred, the subject matter of the regulated conduct, and the race of the person involved in the activity, Indian or non-Indian. Full criminal and civil jurisdiction was extended to all fee land on reservations of nonconsenting tribes and also to all nonfee land "when non-Indians were in-

199 Antelope, 430 U.S. at 648 \& n.9.

${ }^{500}$ Id. at 649 (footnotes omitted).

so1 439 U.S. 463 (1979).

${ }^{802}$ Id. at $500-01$.

${ }^{803}$ Act of Aug. 15, 1953, ch. 505, 67 Stat. 588 (codified as amended at scattered sections of $18 \& 28$ U.S.C. (1976)). For the background and an analysis of Public Law 280, see Goldberg, Public Law 280: The Limits of State Jurisdiction Over Reservation Indians, 22 UCLA L. REV. 535 (1975).

SO4 WASH. REV. CODE $§ 37.12 .010$ (1974). 
volved." ${ }^{\text {"Oos }}$ The state disavowed jurisdiction over all other nonfee land except with regard to eight categories of activity it deemed especially important: compulsory school attendance, public assistance, domestic relations, mental illness, juvenile delinquency, adoption proceedings, dependent children, and operation of motor vehicles. ${ }^{\mathrm{BOB}}$

The Yakima Indian Nation sought a declaratory judgment that the Washington statute violated the fourteenth amendment's due process and equal protection clauses. The district court's denial of declaratory relief was reversed by the Ninth Circuit, ${ }^{507}$ which held that the state had violated equal protection guarantees.

The Ninth Circuit never cited Mancari and explicitly sought to avoid the issue whether the tribe's equal protection claim should be upheld through intermediate or even more exacting judicial scrutiny. Rather, the court held that "Washington's title-based classification fails to meet any formulation of the rational basis test." ${ }^{308}$ Yet, the court's opinion contained elements of what has come to be known as intermediate or middle scrutiny. The most important criterion for assertion of criminal jurisdiction was the status of title: fee or nonfee. To determine whether this criterion was "wholly unrelated"500 to state objectives the court limited its consideration to those objectives articulated by the state attorney general. The court, moreover, noted that it "had no reason to believe the Washington Attorney General . . . was 'selecting a convenient, but false post-hoc rationalization," "\$10 citing Craig v. Boren, ${ }^{511}$ a leading case in the development of intermediate scrutiny for gender discrimination.

The articulated state purpose for asserting jurisdiction in nonfee land over only certain subject areas was that these areas were those " 'in which the state has the most fundamental concern for the welfare of those least able to care for themselves.' "\$12 The court, focusing

${ }^{808} 439$ U.S. at 475 . As is the case with many other tribes in the Northwest whose lands were subdivided during the Allotment Era, the Yakima Indian Nation's reservation had become a checkerboard, comprising three different types of land tenure: tribal trust land; individual Indian trust land; and former tribal land owned in fee simple absolute by Indians or non-Indians. To simplify, the land held in trust is usually called nonfee land and the land held in fee simple absolute is called fee land.

${ }^{306} \mathrm{Id}$. at 475-76.

so7 Confederated Bands and Tribes of the Yakima Indian Nation v. Washington, 552 F.2d 1332 (9th Cir. 1978), rev'd, 439 U.S. 463 (1979).

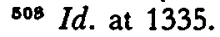

${ }^{509} \mathrm{Id}$.

810 Id. at 1335 n.8.

511429 U.S. 190, 199-200 (1976). The court also cited Reed $v$. Reed, the first gender discrimination case in which the Supreme Court had applied heightened judicial scrutiny. 552 F.2d at 1335 (citing Reed v. Reed, 404 U.S. 71 (1971)).

${ }^{812} 552$ F.2d at 1335 (quoting Transcript at 586). 
solely on the criminal jurisdiction that would be asserted in these eight subject areas, stated that there was no rational connection between the "stated purpose" and the status of land title within the reservation. .13 $^{\text {s1s }}$ In effect the court held that the stated purpose was impermissibly underinclusive: "An overriding concern with . . . public order necessarily embrace[s] both [fee and nonfee land], once the state undertakes to assume any jurisdiction over either." 114

In reversing, the Supreme Court rejected both the Ninth Circuit's analysis of the equal protection claim and the Yakima Nation's argument that the law violated a fundamental right to self-government. As in Antelope, the Court relied on Mancari only for the proposition that classifications singling out Indian tribes are not racial and hence not suspect. ${ }^{\text {.15 }}$ Similarly, the Court's equal protection analysis did not evaluate whether the statute furthered "Congress' unique obligations" to Indians, but only whether the statute was rationally related to the state's purpose. ${ }^{\text {s16 }}$ The Court also dismissed the tribes' fundamental right theory as "untenable"s17 because "[i]t is well established that Congress, in the exercise of its plenary power over Indian affairs, may restrict the retained sovereign powers of the Indian tribes." ${ }^{\text {"18 }}$ Consequently, the legislative classification need only "meet conventional Equal Protection Glause criteria .... [L]egislative classifications are

s23 Id.

s14 Id. By assuming full criminal jurisdiction over fee land but only partial criminal jurisdiction over most nonfee land, the state deprived Indians living on non-fee land of state law enforcement except with regard to the previously noted eight subject areas. Yet the Court held that "[t]he state's interest in enforcing criminal law is no less 'fundamental' . . . on nonfee lands than on fee lands. ... [T] [Te happenstance of title holding is [not] related in any way to the need by the land occupants for law enforcement." Id.

A careful observer may wonder about the basis of the conflict in this case, for the tribe could secure full law enforcement from the state throughout the reservation simply by requesting it. Perhaps the tribe, in fact, desired no state criminal jurisdiction on its reservation. If protection against incursions on its sovereignty were the tribe's goal, the Ninth Circuit's opinion helped advance that goal, for it held that the "whole statute must be rewritten." Id. at 1336. Yet it is doubtful that could be done, since in 1968 Congress amended Public Law 280, prohibiting any additional assertion of state jurisdiction over reservation property without tribal consent. 25 U.S.C. $\$ \S 1321-1326$ (1976); see also Bryan v. Itasca County, 426 U.S. 373 (1976) (statutes such as Pub. L. No. 280 were passed for Indians' benefit and are to be narrowly construed, with doubts to be resolved in favor of Indians).

615439 U.S. at 500-01. Such reliance was inapposite, however, for the classification was racial and not based on tribal status. "State jurisdiction is complete as to all non-Indians on reservations and is also complete as to Indians on [fee] land." Id. at 498. Thus, on nonfee land, the classification determining jurisdiction was Indian versus non-Indian. The statute made no reference to tribal status.

s16 Id. at 501 .

${ }^{\circ 12}$ Id.

${ }_{118}$ Id. 
valid unless they bear no rational relationship to the State's objectives."

The Yakima Indian Nation case perhaps marks a low point in the efforts of tribal advocates to convince the Court to apply more than minimal scrutiny to individual and tribal claims of equal protection violations. While Mancari could theoretically have served as a shield for Indian tribes adversely affected by federal legislation, that shield was transformed in later cases into a judicial sword used to support conclusions that legislation unfavorable to tribes or Indian interests is not race-based and hence not suspect. The only consistent application of Mancari to date has been to uphold the exercise of congressional power and to justify judicial deference to Congress. ${ }^{520}$ The Plenary Power Doctrine may have faded as the explicit analytical theory for justifying the exercise of congressional power, but its doctrinal emanations are

$819 I d$. Note that the tribe relied on an 1855 treaty promise of self-government. $I d$. at 478 n.22. The Court held that Public Law 280 had abrogated any such promise. Id.

Notwithstanding the purported use of "conventional Equal Protection Clause criteria," it could be argued that the Court actually applied something more than rational basis scrutiny, for it stated that the statute must be rationally related to " the purpose identified by the State." "Id. at 500 (emphasis added) (quoting Massachusetts Bd. of Retirement v. Murgia, 427 U.S. 307, 314 (1976)). It thus suggested that it would not hypothesize a statutory purpose to "save" a statute. Yet this concession to "conventional" rational basis criteria is illusory, for the Court permitted the State Attorney General to reformulate the state's purpose and select a "convenient . . . post-hoc rationalization." See Graig v. Boren, 429 U.S. at 200 n.7. The stated objective before the Ninth Circuit for limiting criminal jurisdiction over most nonfee land to eight enumerated subject areas was solely " concern for the welfare of those least able to care for themselves." " 552 F.2d at 1335 (quoting trial transcript). Yet, the Supreme Court held Washington's statutory scheme was "fairly calculated to further the State's interest in providing protection to non-Indian citizens living within the boundaries of a reservation while at the same time allowing scope for tribal self-government on [nonfee] lands." 439 U.S. at 502. In contrast, in its brief the state did not raise protection for nonIndian citizens as a major concern, justifying the statute's exclusion of trust land solely as an accommodation of the value of tribal sovereignty. The extension of jurisdiction over the eight specific subject areas was justified on the basis of the fundamental nature of those areas. Brief for State at 37-39, Washington v. Confederated Bands and Tribes of the Yakima Indian Nation, 439 U.S. 463 (1979). Accordingly, while the means must be rationally related to the "identified" governmental interest, the Court appeared ready to permit the government to restate that interest until it finally formulated an acceptable one. One might fairly conclude that reformulating the reasons for actions, after a challenge to those actions, creates the suspicion of pretext.

${ }^{520}$ See Alaska Chapter, Associated Gen. Contractors of Am., Inc. v. Pierce, 694 F.2d 1162 (9th Cir. 1982) (Indian preference upheld); Livingston v. Ewing, 601 F.2d 1110 (10th Cir.) (Indian preference upheld), cert. denied, 444 U.S. 870 (1979). Dicta in a recent district court opinion states that only legislation benefiting Indians is entitled to deferential review under Mancari. See St. Paul Intertribal Hous. Bd. v. Reynolds, 564 F. Supp. 1408, 1411 (D. Minn. 1983). Nevertheless, laws burdening Indian tribal members have continued to receive deferential treatment. See, e.g., United States v. Yazzie, 693 F.2d 102 (9th Cir. 1982) (subjecting Navajo Indians to different state laws defining incest upheld), cert. denied, $103 \mathrm{~S}$. Ct. 1231 (1983). 
still present. Whatever Congress wants, Congress gets, and Mancari and its progeny are now increasingly impressed to serve that end.

Mancari's most crushing blow to tribal rights is the creation of an analytical mechanism to transmute legislative classifications from the category of suspect race-based into the category of nonsuspect tribebased. Such a transmutation is similar to that employed in Geduldig $v$. Aiello, ${ }^{\mathbf{5 2 1}}$ in which the Court held that a state disability insurance program discriminating against pregnancy disabilities is not gender-based discrimination. "The program divides potential recipients into two groups .... While the first group is exclusively female, the second includes members of both sexes." ${ }^{22}$ The premise of Mancari's tribal status argument (as well as the premise of Geduldig's pregnancy status argument) is faulty and should not stand unchallenged.

Mancari's premise is best understood when placed in contradistinction with that of cases such as Washington $v$. Davis, ${ }^{\text {s23 }}$ Arlington Heights v. Metropolitan Housing Development Corp., ${ }^{\mathbf{5 2 4}}$ and Personnel Administrator $v$. Feeney. ${ }^{\mathbf{5 2 5}}$ In those cases nonracial and nongender criteria, calculated to be applied to multi-racial and multi-gender groups, produced racially discriminatory and gender discriminatory outcomes. Absent proof of a discriminatory purpose, however, the Court refused to find invidious discrimination. The reason is that a purpose to affect adversely a racial or gender group is the central evil equal protection seeks to avoid. ${ }^{526}$ The premise of these cases is that such a purpose cannot be inferred simply from the language of a facially neutral statute because nonsuspect criteria, applied to multi-racial and multigender groups, suggest a legitimate purpose sufficient to support a continuing presumption of constitutionally permissible legislative intent. In contrast, Mancari would apply the same presumption to legislation that adversely affects Indians by creating tribal status classifications. ${ }^{527}$ Such an application is inapposite since the selection criterion is facially racial. The triggering mechanism for receiving unfavorable treatment at the hands of government is the racial status of being an Indian because only Indians are tribal members within the meaning of these statutes. $^{\text {528 }}$ Through facial evaluation of such statutes one can conclude

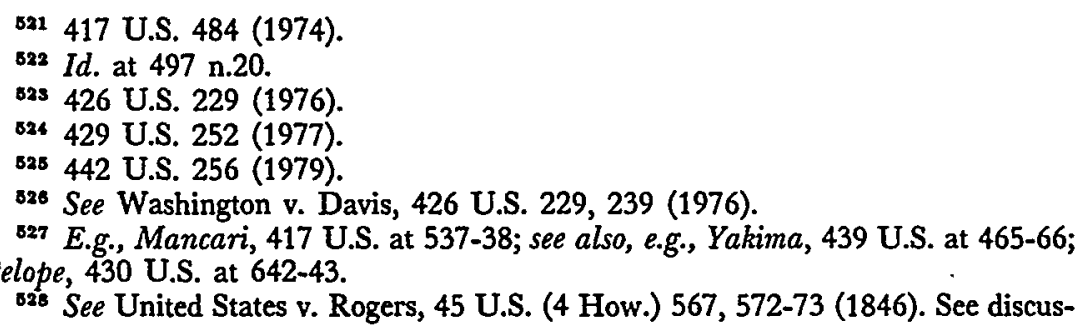


that only Indians will be affected adversely. That assurance of discrimination based on race should create sufficient suspicion of invidious intent to support strict judicial scrutiny because " $[t]$ he central purpose of the Equal Protection Clause . . . is the prevention of official conduct discriminating on the basis of race."

\section{Future Directions for Tribal Advocates}

The discussion of Mancari and the cases following it contribute significantly to the development of this Article's major themes: the scope of congressional power over Indian affairs and particularly the power to substantially invade tribal property and sovereignty rights; the due process limits on the exercise of that power; and the role of the Court in accommodating tribal interests with those of the larger political community.

Mancari held out initial promise for tribal advocates; that promise has been dimmed somewhat by subsequent cases that have transformed Mancari into a statement of deference to congressional power. Advocates must now return to basics and attempt to secure heightened judicial scrutiny by focusing on the values and traditions that underlie judicial protection of discrete and insular minorities and other disfavored classes. At the very minimum, tribal advocates should analyze legislation carefully; if, as clearly in Moe, ${ }^{\mathbf{5 3 0}}$ seemingly in Yakima, ${ }^{\mathbf{5 3 1}}$ and potentially in Antelope, ${ }^{\mathbf{5 2}}$ the legislation classifies in terms of Indian and non-Indian, rather than in terms of tribal Indian and others, they should argue that the Mancari tribal status analysis is simply inapplicable. Such classifications are race-based, and courts must at least be presented with that understanding.

Attacks on purely racial statutes are insufficient, however. Tribes must argue that legislation adversely affecting Indians on the basis of tribal status is racially discriminatory per se. While Geduldig may be an overwhelming precedent, advocates can argue that Geduldig was a gender classification, traditionally not afforded the strictest scrutiny. Indian legislation involves racial groupings, an area in which the Court has traditionally not deferred to congressional judgments and has strictly scrutinized legislative purpose and means.

In the event tribal advocates are unsuccessful in limiting Geduldig

sion supra text accompanying notes 71-80.

529 Washington v. Davis, 426 U.S. at 239.

sso See supra notes 454-58 and accompanying text.

ssi See supra notes 501-19 and accompanying text.

s32 See supra notes 484-500 and accompanying text. 
to gender classifications, they could distinguish Geduldig by arguing that the relevant classification under equal protection analysis is "tribal status" and that the classification of tribal status in and of itself has the indicia of a suspect or disfavored class. ${ }^{\text {533 }}$ As argued above, ${ }^{\text {bs4 }}$ Indian tribes are a paradigmatic example of minorities vulnerable to and excluded from the majoritarian political process. The only factor present in the classification "tribal status," yet not present in classifications afforded protection from the majoritarian process by the Court, is that tribal status is seemingly alterable; ${ }^{535}$ a tribal Indian can sever his or her connections with the tribe and assimilate into the mainstream of society. Thus, the classification of tribal status is potentially not as well-defined or discrete as race or even gender. ${ }^{\text {.36 }}$ Tribes should counter this argument, however, by educating the courts to the central significance of a tribe and tribal membership to a tribal Indian's concept of dignity and personhood. ${ }^{\mathbf{6 3} z}$ Once the importance of this relationship is understood, courts may see that concluding that tribal status is alterable is akin to arguing that gender is similarly alterable because of the existence of sex-change operations.

There are other equal protection and due process arguments to be made that may offer protection to tribal property and sovereignty rights. Tribes should attempt to build their case for heightened scrutiny by stressing both the importance of the right affected adversely by federal legislation and the unique status of Indians as a disfavored class. ${ }^{\text {sss }}$ Reference must be made again and again to the central importance of land and sovereignty to the identity of Indians as a people, to the long and ignominious history of mistreatment, and to the rights of political association the Court has protected under the first amendment. The

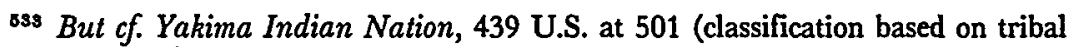
status not suspect).

sat See supra notes $282-92$ and accompanying text.

sss See, e.g., Michael M. v. Sonoma County Super. Court, 450 U.S. 464, 477-78 (1981) ("The Constitution is violated when government . . . invidiously classifies similarly situated people on the basis of the immutable characteristics with which they were born.") (Stewart, J., concurring).

${ }^{\text {bs6 }}$ Cf. Massachusetts Bd. of Retirement v. Murgia, 427 U.S. 307, 313-14 (1976) (per curiam) (older persons not a discrete and insular group because "each of us will reach [old age]"); San Antonio Indep. School Dist. v. Rodriguez, 411 U.S. 1, 22-28 (1973) (class of poor persons receiving inferior education due to property tax financing of school districts is too diverse and amorphous to warrant strict scrutiny).

8s7 See supra notes $268-78$ and accompanying text.

sss San Antonio Indep. School Dist. v. Rodriguez, 411 U.S. 1, 109 (1973) (Marshall, J., dissenting). The Court employed a sliding scale approach to judicial scrutiny of legislation in a recent case invalidating a state statute denying access to education, an important, although not fundamental, right, triggering heightened scrutiny. Plyler v. Doe, 457 U.S. 202, 223-24 (1982) (legislation must further a "substantial goal" of the state). 
time may not yet be ripe for the courts to accept these arguments, but tribal advocates must keep them before the courts. Only through persistent efforts and arguments will advocates be able to convince the courts of the inappropriateness of such total deference to congressional power as demonstrated in Yakima Indian Nation. Only with repeated reminders to the courts of the equal protection and due process arguments at issue can the lingering melody of the plenary power era be silenced. 